\title{
The Ideological Basis of the Grexit Debate
}

\author{
Kirk Bansak - Stanford University \\ Michael M. Bechtel - University of St.Gallen \\ Jens Hainmueller - Stanford University \\ Yotam Margalit - Tel Aviv University
}

November 2015

\begin{abstract}
What explains the sharp divide among European publics over the "Grexit," that is, the possibility of allowing Greece to default and leave the Eurozone? Being part of a currency union can provide its member states with benefits, but when a member state faces default, maintaining the currency union can impose substantial redistributive costs on the other members, giving rise to disagreements over the desired policy response. We explore such an instance, examining the divisions underlying the Grexit debate using original survey data from four of the largest European economies. We contend that divergent economic interests among citizens, as well as the often-mentioned chasm between supporters of mainstream and extremist parties, provide little insight into the domestic divide over the Grexit. Instead, we argue that the key factor was the split between left and right. We lay out a set of theoretical explanations for the prominence of left-right ideology in structuring the public debate. Testing these arguments, we find that the primary mechanism was a systematic difference between left and right voters in expectations about the economic consequences of a Grexit, the outcome of which some perceive as the free market's dictate.
\end{abstract}

\footnotetext{
Kirk Bansak, Department of Political Science, Stanford University, 616 Serra Street, Stanford, CA 94305, United States, kbansak@stanford.edu. Michael M. Bechtel, Swiss Institute for International Economics and Applied Economic Research, University of St.Gallen, Rosenbergstrasse 51, CH-9000 St.Gallen, Switzerland, michael.bechtel@unisg.ch.

Jens Hainmueller, Department of Political Science and Graduate School of Business, Stanford University, 616 Serra Street, Stanford, CA 94305, United States, jhain@stanford.edu.

Yotam Margalit, Department of Political Science, Columbia University, 702 IAB, Mail Code 3320, United States, ym2297@columbia.edu.
}

We gratefully acknowledge financial support from the Swiss National Science Foundation (grant \#100017_146170/1 and grant \#PP00P1-139035). Any errors remain our own. 


\section{INTRODUCTION}

The financial crisis in Europe reached a boiling point in mid-2015, when intense negotiations between the Greek government and its main creditors appeared to reach a deadlock. Without an agreement, the Greek government was to be denied financial assistance, and thus many viewed a default and subsequent exit from the Eurozone - a "Grexit" - as a likely scenario. Greek citizens, many of whom worried about further austerity measures, hotly debated the tough conditions demanded by the creditors as part of any deal. Yet, the agreement and its terms also divided citizens of many other European nations. In particular, disagreement centered on the desirability of a Grexit. Whereas some supported another bailout to ensure Greece stayed within the Eurozone, others opposed additional financial transfers and viewed a Grexit as an acceptable, preferred, or even necessary outcome.

This was, in fact, the first time since the formation of the Eurozone that citizens of member states were debating the very real prospect of another member state being forced out of the currency union. Unsurprisingly, arguments invoking a range of considerations - economic interests, nationalism, European solidarity, and historical precedents - were made and contested by both supporters and opponents of a deal. What explains the contours of this divide over assistance to Greece and the potential outcome of a Grexit? More generally, how do publics weigh the value of maintaining a currency union?

We address these questions using original data collected in a cross-national survey that we administered to national samples in four of the largest European countries: France, Italy, Spain, and the United Kingdom. The data, gathered during the negotiations and at the height of the Greek debt crisis in 2015, allow us to assess the role of egocentric economic considerations in shaping individuals' attitudes. We also examine the influence of other potential factors, such as people's economic sophistication or knowledge on the topic. The statistical evidence linking these factors and attitudes on the Greek crisis is overall weak and offers limited explanatory power.

In contrast, we find a striking pattern whereby the deepest cleavage among publics in Europe 
on the Grexit question runs along the ideological left-right divide. This finding counters many accounts explaining attitudes on EU integration, which describe a cross-cutting or inverted U-curve in which pro-EU centrist voters are pitted against anti-EU voters on the ideological periphery (Hix and Lord, 1997; Taggart, 1998; Hooghe et al., 2002). In fact, our analysis shows that the disagreement in the Grexit debate was structured by the traditional left-right divide, with a linear-like relationship manifesting in the samples for all four countries. We find that placement on the ideological spectrum is, by far, the strongest predictor of individual attitudes on the Grexit question, even controlling for a wide range of other predictors. We then explore why that is the case. Why has a cleavage that tends to divide publics on domestic policy questions come to structure people's position on a foreign policy issue, namely the possible default and exit of a currency-union member state? Building on earlier research, we propose four possible explanations for the prominence of the left-right divide on this matter, and we subject each of the explanations to tests.

The first explanation holds that because the Grexit debate required financial assistance amounting to redistribution at the international level, this may have led to a reproduction of the same political divisions that characterize debates over domestic redistribution. A second explanation centers on the possible differences between left and right voters in levels of empathy. Attitudes on the use of taxpayer funds to assist a target in need, in this case a foreign state, may reflect citizens' ability or willingness to empathize with the unfortunate and downtrodden. Third, left and right voters may differ systematically in their broader attitudes toward EU integration, in which case disagreement on the question of assistance to Greece perhaps reflects different interests with respect to strengthening or weakening the integration project. Finally, the divide may reflect different sociotropic concerns among left and right voters about the likely effects of a Grexit on the larger European economy. If the two camps hold systematically divergent expectations about the impact of Greece leaving the Eurozone, this could account for the prominence of the ideological cleavage in the current debate.

Our empirical investigation disconfirms the first two explanations and casts doubt on the third. We find that individuals who hold very different views on domestic redistribution exhibit, 
on average, almost identical views on the Grexit question. Similarly, we find that attitudes of people with different levels of empathy are not different with respect to the question of assistance to Greece. With respect to broader attitudes toward EU integration we find that pro-EU attitudes is correlated with opposition to the Grexit, but there is a lack of a clear correspondence between left-right ideology and EU attitudes (left graph) which casts doubt on the idea that this mechanism provides a pivotal explanation for the observed ideological divide on the Grexit. In contrast, our evidence is consistent with the fourth account, namely that left and right hold very different views regarding the likely impact of a Grexit: whereas many on the left end of the ideological spectrum believe a Grexit would damage the European economy, the proportion who believe it would have a positive impact increases systematically when moving toward the right in all four countries. We offer a number of empirical tests that give credence to this claim of divergent beliefs about broader economic outcomes, in contrast to egocentric economic concerns, as a key channel accounting for the striking left-right divide on the Grexit question.

Our results contribute to the growing literature debating the link between the ideological leftright divide and foreign policy positions beyond the American politics context. A core question in this debate is the extent to which the left-right cleavage structures voters' preferences on issues relating to international cooperation, trade, immigration or EU integration (Gabel and Hix, 2002; Hooghe and Marks, 2008; Milner and Judkins, 2004; Milner and Tingley, 2011; Noël and Thérien, 2008; Therien and Noël, 2000). Our findings in the Grexit debate context indicate that, in fact, the left-right ideological cleavage remains a central factor in structuring mass opinion on foreign economic policy issues. The results also highlight the importance of the often-overlooked issue of voters' economic expectations. The findings - namely, that left and right voters exhibit systematically different assessments regarding the expected impact of a Grexit on Europe's economy - open the door for future research on the causes of voters' beliefs about policy outcomes. Our study provides some evidence that those beliefs reflect differences in views about the effects of interventions in the free operation of the market. In the discussion section, we discuss the broader implications of this divergence in expectations. 


\section{Opposition to the Grexit: Economic Interests and Ideology}

A currency union resembles a club that provides its members with benefits, such as lower consumer prices and inflation (Padoan, 1997, 2004). Yet, once countries have formed a currency union, member states often face collective action problems. These problems arise because, within the club, membership benefits are often non-excludable regardless of who produces them. If a member state or a group of member states experience an economic shock, maintaining a stable common currency requires the club to incur costs. But since the benefits of an effective crisis response constitute a public good to all member countries, governments have an incentive to free-ride on the stabilization efforts of other member states. As a consequence, the club may fail to craft a common response capable of saving the struggling member state, which may result in this country having to exit the common currency with potentially dramatic political and social repercussions.

In solving the collective action problem and saving a debt-ridden member state to keep it in the currency union, domestic political support may be crucial. If publics in the currency union's member states support the idea of saving the struggling member, this counteracts governments' incentive to free-ride on other donor countries. This possibility, however, depends on the level and structure of domestic disagreement: Who is in favor of the crisis country leaving the currency union and who is against? Which theories account for the variation in support for an exit? So far, there do not exist any studies that have examined mass support for an exit of a country from a currency union. However, our analysis can build on previous work that has explored individuals' domestic and foreign economic policy preferences.

The literature on individual policy preferences has increasingly focused on the question of whether citizens form their views mainly because of economic interests or different types of social, ideological, or moral convictions. For example, some have argued that incomerelated (Kaltenthaler et al., 2004; Scheve and Slaughter, 2001), occupational (Gabel, 1998), consumption-based (Baker, 2005), and job security concerns (Naoi and Kume, 2011) explain variation in support for free trade among members of the public. Others, however, have empha- 
sized the ideological and norm-based sources of public support for trade liberalization (Bechtel et al., 2012; Hoffman, 2009; Hainmueller and Hiscox, 2006; O'Rourke and Sinnott, 2001). These arguments have also been applied to illuminate the political basis of support for monetary integration. Gabel and Hix (2005) examine public support for the Euro in Britain, where they find that factors related to national identity and democratic ideals significantly predict attitudes toward the Euro. Recently, Bearce and Tuxhorn (2015) show that preferences over monetary policy in the United States reflect individuals' firm-based occupational interests: respondents working for firms that have international trade ties prefer a monetary policy that prioritizes currency stability. To extend this line of research on the sources of foreign economic policy views, the following develops theoretical arguments about the factors that should help explain opposition to the Grexit.

\section{A. The Ideological Center-Periphery Divide}

Scholars studying citizens' attitudes on European economic integration have long argued that a key dividing line is that between supporters of mainstream and extremest parties. Whereas the former embrace what is widely seen as a liberal economic arrangement, voters of extremist parties oppose EU integration due to concerns on issues such as immigration and loss of national sovereignty, or as an expression of discontent with mainstream politics. Indeed, evidence in support of the ideological center-periphery cleavage has been documented with respect to European integration in general (Hix, 1999; Markowski and Tucker, 2005) as well as with regard to more specific policy issues such as EU fiscal policy, employment, and integration initiatives (Hooghe et al., 2002). If assistance to Greece represents an extension of the broader question

of EU integration, the center-periphery distinction may structure the cleavage in attitudes over the Grexit.

Hypothesis 1 (Ideological Center-Periphery Cleavage) Individuals on the ideological extremes will support an exit of Greece more strongly than those in the ideological center. 


\section{B. The Left-Right Cleavage}

An alternative view holds that the debate over keeping a member state within the union would divide publics along a traditional left-right cleavage. This may be due to a number of reasons, such as opposing views on redistributive measures, differences in levels of empathy toward the unfortunate, divergent beliefs about the efficacy of market-based outcomes as opposed to government-led intervention, or differences in attachments to national and EU identities. For any of these reasons (all of which we discuss in detail later), the left-right dimension could be central to explaining the divisions in the Grexit debate.

Hypothesis 2 (Ideological Left-Right Cleavage) Individuals on the ideological left will be more opposed to an exit of Greece from the Eurozone than those on the right.

\section{Economic Interests}

Another line of explanation for the variation in views on assistance to Greece and a possible Grexit centers on how individuals expect such outcomes to affect their own economic standing. If this approach has merit, the key dimension likely to shape citizens' attitudes on a Grexit is the extent to which their earnings are exposed to changes in market conditions following a Greek default and possible exit from the currency union. Such exposure could take various forms. For example, citizens that own financial assets such as stocks and bonds will be more adversely affected than others if a Greek default leads to bearish financial markets. Other exposure could be in terms of real estate investments that are tied to changing interest rates. In particular, individuals that have a large mortgage to pay out will be less immune to a market downturn as compared to citizens who rent or own their home with no loans to repay. As a result, one would expect mortgage owners to exhibit greater support for actions aimed at staving off a Grexit.

A different form of exposure to Greece's plight could perhaps arise from dependence on government assistance. If citizens expect that providing further financial aid to Greece would come at the expense of funds available for spending on domestic social programs, those who are more dependent on government assistance - the unemployed, the poor, and other segments of 
society whose primary source of income is some public source - should be less opposed to their government shunning Greek requests for financial assistance.

In sum, the economic self-interest logic gives rise to the following expectations:

Hypothesis 3 (Asset Ownership) Ownership of financial assets will increase opposition to a Grexit.

Hypothesis 4 (Mortgage Holders) Mortgage owners will be more opposed to a Grexit than renters or non-mortgaged homeowners.

Hypothesis 5 (Welfare recipients) The poor, unemployed, and other beneficiaries of public income sources will be less opposed to a Grexit.

\section{DATA}

To test these hypotheses, we designed and fielded an original online survey in France, Italy, Spain, and the United Kingdom. The surveys, carried out among national samples in May 2015, were administered by Respondi, an international polling firm. We made a substantial effort to match the known population margins on socio-demographic and regional variables. ${ }^{1}$ The total number of respondents was about $12,800 .^{2}$ Our main outcome variable measures opposition to the Grexit using the following question:

"Some people would like Greece to exit the Eurozone (i.e. use a currency other than the Euro). Others prefer Greece to remain in the Eurozone (i.e. keep the Euro as its currency). Where do you stand on this issue? Do you favour or oppose a Greek exit from the Eurozone?"

Possible answers were "strongly favor," "favor," "neither favor nor oppose," "oppose," or "strongly oppose." For those respondents who answered "neither favor nor oppose," we included a branch in which we asked:

\footnotetext{
${ }^{1}$ Tables A.1 to A.3 report the distributions of the socio-demographics in detail.

${ }^{2}$ The number of observations by country are: France: 3886, Italy: 3473, Spain: 3471, United Kingdom: 2009.
} 
"If you had to decide, would you say you favour or oppose a Greek exit from the Eurozone?"

Since we offered only two possible answers to this branch, "favor" and "oppose," we elicited a position on the Grexit issue for all respondents. For ease of interpretation, we converted the measure into a binary variable that equals 1 for respondents that either oppose or strongly oppose the Grexit and is 0 for respondents who favor or strongly favor the Grexit. The analysis presented in this paper employs the binary form of our Grexit attitude variable. ${ }^{3}$

We measure left-right ideology using the standard question wording: "In politics people often talk of 'left' and 'right'. On this scale from 0 (left) to 10 (right), where would you classify your own political views?" To map out the ideological cleavage in detail, we distinguish between far left (0-2), left (3-4), center (5, median), right (6-7), and far right (8-10). ${ }^{4}$ We use the center as the reference category in our regression models. Table A.5 in the Appendix shows the distribution of political ideology by country.

We included a large set of items capturing respondents' economic and financial circumstances. $^{5}$ To measure respondents' general economic situation, we collected information on income and employment status. To measure more specific types of financial concerns that relate directly to the theoretical arguments we also collected information about asset ownership by asking respondents to report whether they currently did or did not "have money invested in stocks, bonds, mutual funds, money market funds or other listed securities." To measure financial exposure in the housing market, respondents were asked to report (a) whether or not they currently had a mortgage, and (b) whether or not they currently owned a home.

To empirically explore the potential mechanisms linking ideology and Grexit attitudes laid out above, we also collected several information about respondents' (a) preferences for income redistribution, (b) general attitudes toward government intervention, (c) levels of interpersonal

\footnotetext{
${ }^{3}$ The results of the same analyses performed using a 5-point ordinal version of the variable are similar to the results presented in this paper.

${ }^{4}$ The cut-points used to construct the five ideological bins were chosen in order to optimize balance in the size of the bins. The results of the analyses presented in this paper are similar when ideology is coded as far left (0-1), left (2-3), center (4-6), right (7-8), and far right(9-10). In addition, data were also collected on respondents' party identification, and analyses employing party identification in place of left-right ideology are also consistent.

${ }^{5}$ Table $\mathrm{A}$ in the Appendix provides details about the question wording and answer categories.
} 
empathy, (d) support for the EU, and (e) expectations regarding the economic impact of a Grexit.

\section{Results}

We begin by assessing the basic distribution of support and opposition to an exit of Greece from the Eurozone. Table 1 reports the results pooled and separately by country. Overall, the Grexit issue divides the public in the four countries: $45 \%$ of all respondents favor Greece leaving the common currency while 55\% oppose the Grexit. However, opposition to the Grexit varies across countries. We find the least support for a Grexit in Spain (36\%) while a larger share of the population would prefer a Grexit in Italy and France ( $43 \%$ and $45 \%$, respectively). In the UK, a substantial majority of $63 \%$ actually supports Greece leaving the Eurozone. This may reflect that the United Kingdom still has its own currency and therefore, British citizens presumably expect that an Exit of Greece from the Eurozone would not affect them much.

Table 1: Support for/Opposition to an Exit of Greece from the Eurozone in France, Italy, Spain, and the United Kingdom (in \%)

\begin{tabular}{cccc}
\hline Sample & $\begin{array}{c}\text { \% Support Grexit } \\
\text { (\# respondents) }\end{array}$ & $\begin{array}{c}\text { \% Oppose Grexit } \\
\text { (\# respondents) }\end{array}$ & $\begin{array}{c}\text { (total \#) } \\
\text { Full }\end{array}$ \\
\hline \hline France & $45 \%$ & $55 \%$ & \\
& $45 \%$ & $(7,053)$ & $(12,839)$ \\
Italy & $(1,753)$ & $55 \%$ & \\
& $43 \%$ & $(2,133)$ & $(3,886)$ \\
Spain & $(1,501)$ & $57 \%$ & \\
& $36 \%$ & $(1,972)$ & $(3,473)$ \\
United Kingdom & $(1,265)$ & $64 \%$ & \\
& $63 \%$ & $(2,206)$ & $(3,471)$ \\
& $(1,267)$ & $37 \%$ & $(2,009)$ \\
\hline
\end{tabular}

Note: This table reports the share of individuals supporting/opposing the exit of Greece from the Eurozone (Grexit) with the absolute numbers in parentheses.

Which of the theoretical arguments developed above best accounts for the variation in public attitudes over the Grexit? We begin by assessing the two main competing hypotheses about 
the role of ideology in structuring the debate over the Grexit (Hypotheses 1 and 2). Figure 1 presents the raw differences in opposition to the Grexit as a function of respondents' position on the ideological left-right scale, with centrist voters serving as the baseline. The upper panel shows the results for all countries. The lower panel shows the results by country. When looking at the pooled data, we find that voters' left-right position strongly correlates with their views on the Grexit question: Support for a Grexit increases as one's position shifts rightwards on the ideology scale. On average, citizens situated on the far left are about 17 percentage points more likely to oppose a Grexit than those located at the center of the ideological spectrum and leftist individuals have a 14 percentage points higher probability of opposing a Grexit. In contrast, those on the right have a substantively lower probability of opposing the Grexit (5 percentage points) and individuals located at the far right are about 16 percentage points less likely to oppose Greece leaving the Eurozone as compared to those in the ideological center. This means that individuals on the far right have a 33 percentage-point lower probability of opposing the Grexit than on the far left, an immense difference in substantive terms (the average level of opposition to the Grexit is $55 \%$, see Table 1). Strikingly, this pattern persists with only minor deviations across all four countries in the sample: The more to the left an individual is located ideologically, the higher opposition to the idea of letting Greece exit the Eurozone. Overall, this suggests that a left-right divide underlies the Grexit issue and not a center-periphery cleavage.

To ensure that pattern uncovered in Figure 1 does not simply result from the coding rule used for constructing the five ideology bins, Figure 2 presents bivariate LOESS fits of Grexit opposition predicted using the full 11-point (0-10) ideology variable for each country. We find that the relationship between ideology and Grexit attitudes appears almost monotonic, with the only conspicuous deviation from a generally linear-like trend being those toward the far left end of the spectrum in Spain. Yet, even though the far left in raw terms may appear to be slightly less or similarly opposed to the Grexit than the moderately left, the far left is still more opposed to the Grexit than the center, right, and far right. The reason for this far-left non-linearity in Spain likely has to do with the rise of left-wing anti-EU parties, such as Podemos, in the wake of the debt crisis in Spain. Figure 1 also clearly illustrates the substantial magnitude 
Figure 1: The Relationship between Opposition to the Grexit and Left-Right Ideology

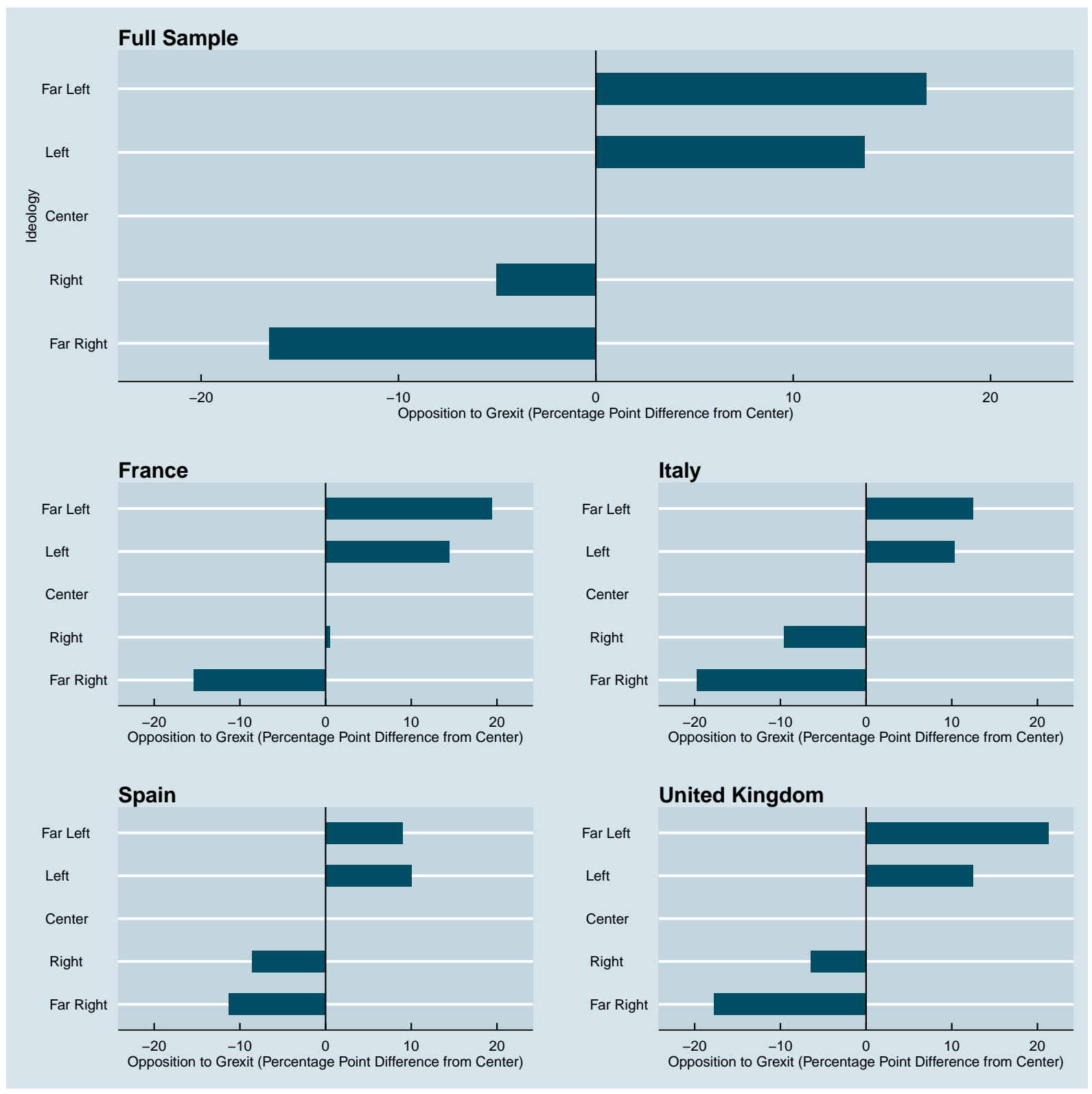

Note: This figure shows the differences in opposition to Greece leaving the Eurozone (Grexit) by ideology groups. The upper panel shows the results across all countries. The lower panel reports the results by country. Opposition to the Grexit is measured using the question "Some people would like Greece to exit the Eurozone (i.e. use a currency other than the Euro). Others prefer Greece to remain in the Eurozone (i.e. keep the Euro as its currency). Where do you stand on this issue? Do you favour or oppose a Greek exit from the Eurozone?" Answers on a five-point scale were converted into a binary variable that equals 1 for respondents that either oppose or strongly oppose the Grexit and is 0 for respondents who favor or strongly favor the Grexit.

of the ideological divide in support for the Grexit. In all countries, among the left there is a sound majority opposing the Grexit while among the right there is a sound majority supporting the Grexit. Again, the only exception is Spain where among the left there is sounds majority 
opposed to the Grexit, but among the right there is about a 50/50 split.

Figure 2: The Relationship between Opposition to the Grexit and Ideology by Country

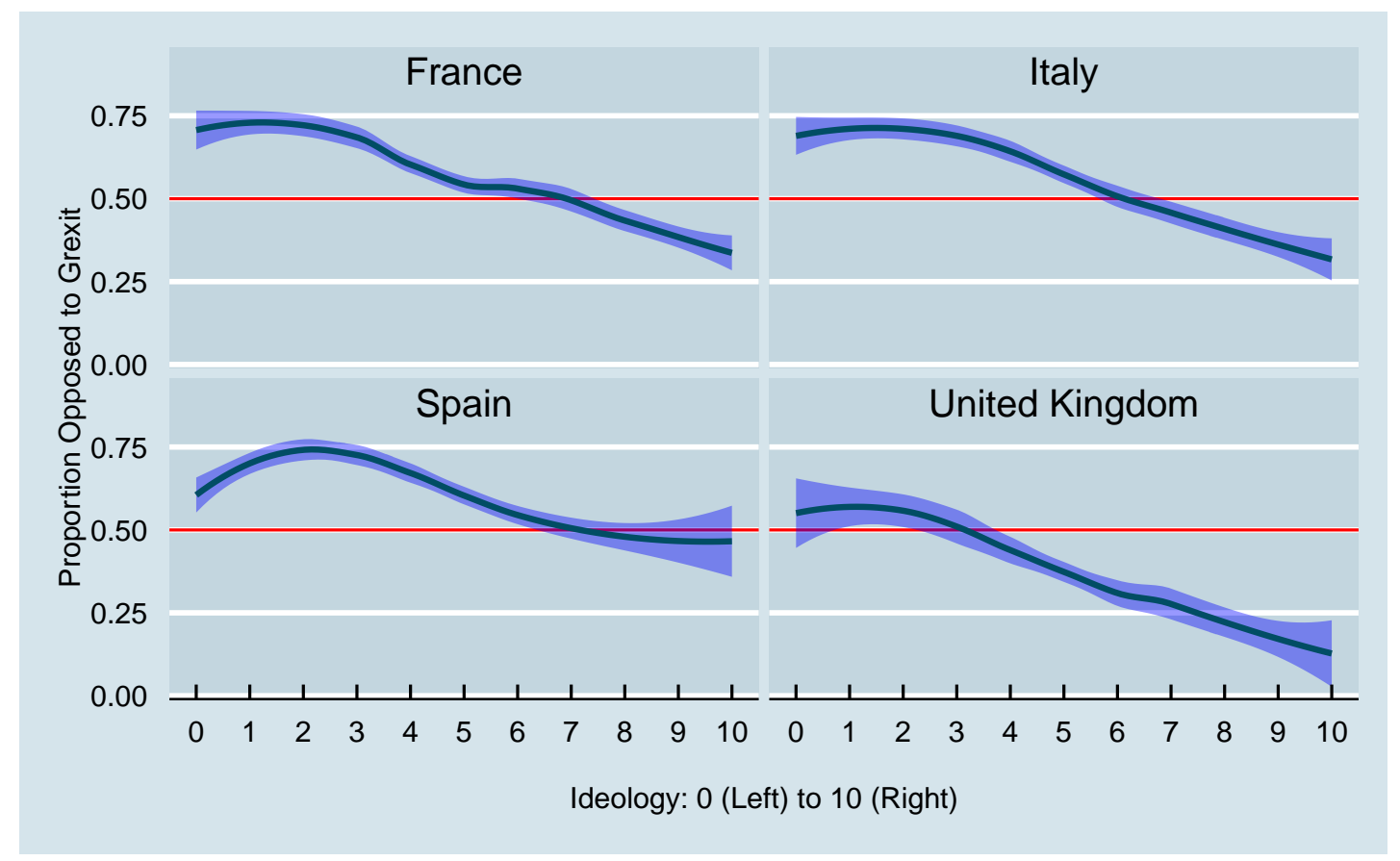

Note: The plots show the predicted share of opposition to the Grexit from a LOESS model using the full 11-point (0-10) ideology variable.

As a final verification of the relationship observed between left-right ideology and Grexit opposition, we use data on our respondents' party identification. For each party with which at least 100 respondents identified, we calculated the proportion of those party identifiers who are opposed to the Grexit. ${ }^{6}$ In addition, we assign each of those parties a left-right placement score using the results of the 2014 Chapel Hill Expert Survey, which employs the same scale ranging from 0 (left) to 10 (right). This allows us to examine the relationship between a party's left-right ideological position and the proportion of respondents identifying with that party who oppose the Grexit. The results, displayed in Figure 3, are strikingly consistent with the pattern already illustrated. On average, the further right is the ideological placement of a party, the smaller is the proportion of the respective party identifiers who oppose the Grexit. This relationship holds up and appears linear-like in all four countries.

\footnotetext{
${ }^{6}$ This accounts for approximately $60 \%, 62 \%, 62 \%$, and $77 \%$ of the respondents in the sample for France, Italy, Spain, and the United Kingdom, respectively.
} 
Figure 3: The Relationship between Left-Right Party Placement and Opposition to the Grexit among Party Identifiers by Country

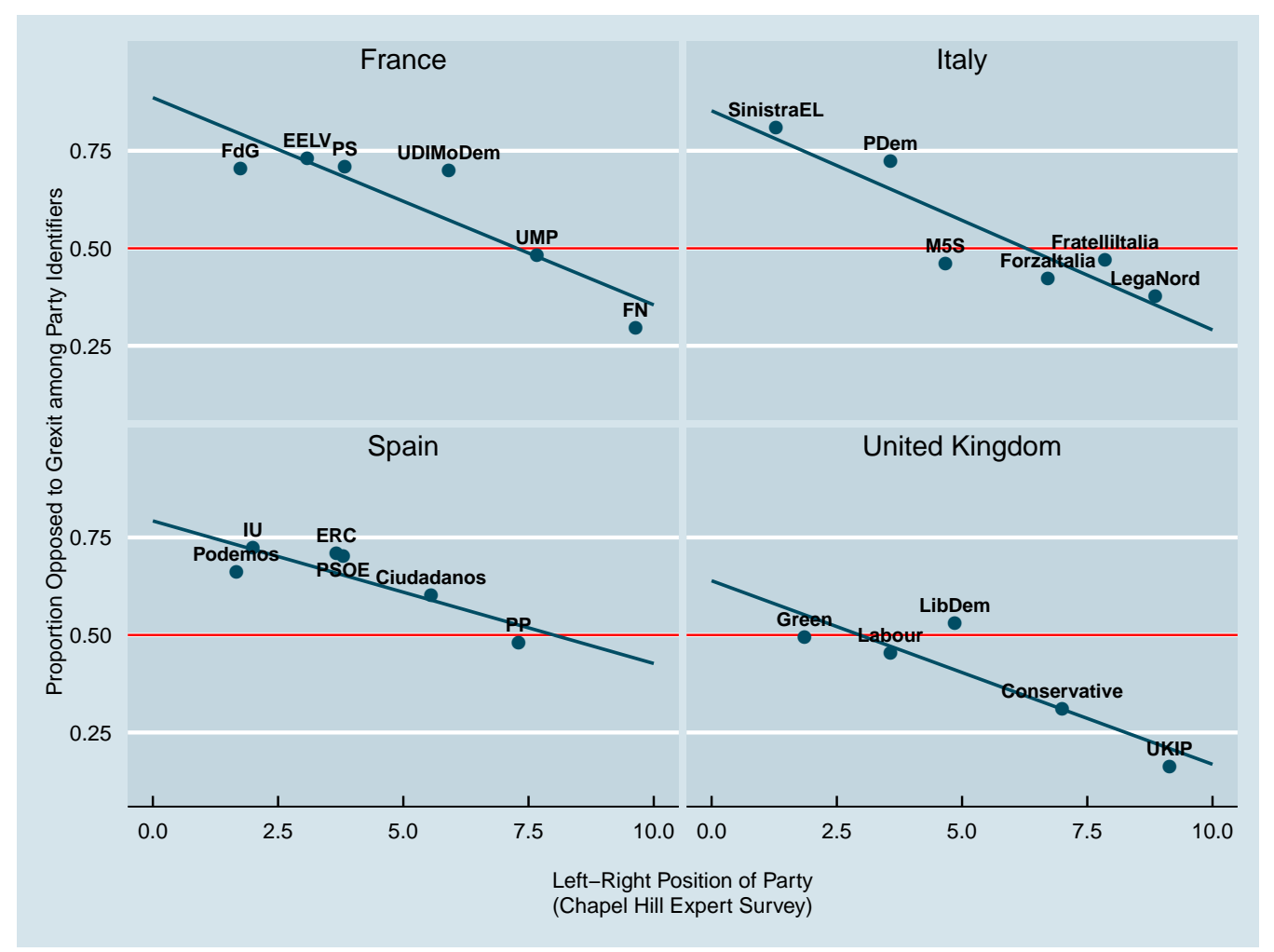

Note: The plots show the proportion of party identifiers who are opposed to the Grexit for mainstream parties in each country. Included in the plots are all parties with which at least 100 respondents in the sample identified. The fitted lines are linear regression lines.

Next, we examine the robustness of the left-right relationship with Grexit opposition to the inclusion of controls. Figure 4 reports results from a linear probability model in which we regress opposition to the Grexit on indicator variables denoting voter's position on the left-right scale, along with a large set of socio-demographics variables and country fixed effects. Ideology accounts for a substantial share of the variation in support for the Grexit. As before, we find that those on the left are significantly more opposed to the Grexit than individuals in the center (the reference category) or on the right. Examining the results separately by country, the finding remains unchanged. As this pattern highlights, the publics in the four countries are sharply divided on the Grexit question along a left-right cleavage rather than a center-periphery divide.

Strikingly, we find that views on the Grexit only weakly correlate with the various economic factors included in our analysis. Views on the Grexit hardly vary across income groups, in both 
Figure 4: The Correlates of Opposition to the Grexit
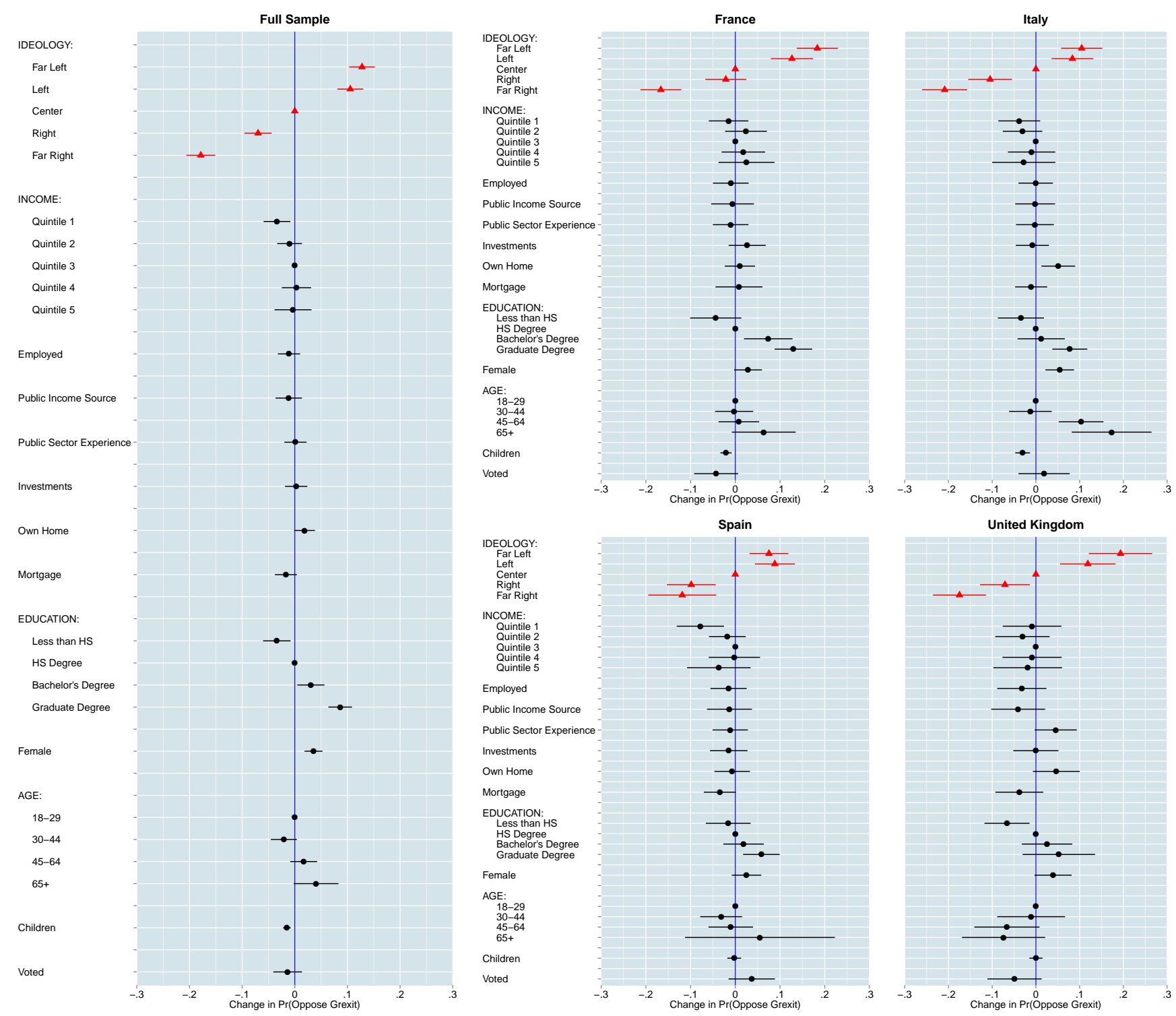

Note: The plots show the marginal effect estimates with $95 \%$ confidence intervals from regressions of the binary Grexit opposition outcome variable on the predictor variables. Dots without confidence intervals mark the reference categories for the respective predictors.

the pooled regression and the country-specific regressions. Other measures of economic exposure to potential market shifts resulting from a Grexit also reveal small or no effects. Employment status, reliance on government assistance, owning financial assets or a home, and holding a mortgage are all associated with substantively small shifts, mostly insignificant in statistical terms. Women and individuals with higher educational backgrounds appear overall to be more apprehensive about a Greek default and exit from the Eurzone. In addition, we see that overall 
age differences have a small effect in the pooled regression, but this finding masks some heterogeneity across countries. In Italy in particular, older individuals are distinctly more opposed to a Grexit. However, the substantive magnitudes of these differences pale in comparison to the differences across ideological groups.

Taken together, we find little evidence to suggest that personal economic considerations account for much of the variation in attitudes toward the Grexit debate. We also find no support for the view that the Grexit issue pits centrist voters against those on the ideological extremes. Rather, we see a discussion dominated by the traditional left-right split, by far the strongest cleavage structuring the debate. Why is that the case? Earlier, we briefly posed four potential reasons why disagreement over a foreign economic policy question might be defined along the left-right divide. In what follows, we tease out the logic of these explanations, lay out their key observable implications, and then subject each one to an empirical examination.

\section{Why does the Left-Right Divide Structure the Grexit Debate?}

\section{A. Key Explanations}

\section{A.1. Redistributive Concerns}

One explanation that predicts a left-right divide on mass support for the Grexit relies on the idea that an important dimension underlying ideological differences is individuals' views on income redistribution. The left generally favors policies that reduce income differences and provide welfare support for the needy. The right, in contrast, prefers that the state minimizes its involvement in terms of shaping the distribution of wealth. If the Grexit is perceived by citizens in the donor countries as a redistributive measure, since it requires the funneling of taxpayer funds to the Eurozone's hardest hit members, that could translate into a cleavage that mirrors the domestic debate over social-economic policies.

Hypothesis 6 (Mechanism: Redistributive Concerns) (a) Left wing voters will be more supportive of redistribution at the domestic level; (b) The share of individuals opposing (supporting) the Grexit will be higher among individuals who support (oppose) redistribution at the 
domestic level.

\section{A.2. EMPATHy GaP}

Left-right differences in views on the Grexit may also stem from differences in other-regarding preferences. If left-wing attitudes reflect higher levels of empathy toward the desperate and afflicted, then media reports of the ongoing economic hardships among the Greek populace may have resonated more strongly among left-leaning voters in other European countries. The common portrayal of a Greek default and Eurozone exit as an outcome that would worsen the country's suffering should then also translate into harder opposition among the left to a Grexit. ${ }^{7}$

Hypothesis 7 (Mechanism: Empathy Gap) (a) Left wing voters exhibit higher levels of empathy than voters on the right; (b) The share of individuals opposing (supporting) the Grexit will be higher among individuals who exhibit higher (lower) levels of empathy.

\section{A.3. EU SupporT}

As noted earlier, studies of public attitudes toward EU integration have initially suggested that the key divide is that between centrist voters and those on two ideological extremes (Hix and Lord, 1997; Taggart, 1998; Hooghe et al., 2002). Yet more recently, some studies have suggested that the debate over the EU has been transplanted into the traditional left-right divide (CITE). More specifically, voters on the left exhibit greater support for the EU project, while those on the right are increasingly apprehensive about yielding national authority to a supranational entity.

In the context of the Greek crisis, voters on the left may believe that EU integration crucially hinges on the Eurozone's ability to demonstrate solidarity with the region's weaker members in times of crisis. For the same reason, voters on the right might support letting Greece default and leave the common currency union. This logic suggests that we should observe the following:

\footnotetext{
${ }^{7}$ To be sure, there is no consensus on this point. Some have argued that a Grexit would actually lessen Greeks' suffering in the long-term as it would allow them to rebuild their economy with a new and sharply devalued currency and absolve them of accepting harsh new austerity measures.
} 
Hypothesis 8 (Mechanism: General EU Support) (a) The share of individuals supporting the European Union is higher among left wing voters than among individuals on the right; (b) EU supporters are more opposed to a Grexit.

\section{A.4. Expected Grexit Impact}

A central aspect of political ideology is defining a position about the desired role of the state and the market in allocating economic resources. Whereas the right generally holds that societies should rely on the free market to allocate resources efficiently, the left holds that persistent market failures and morally-arbitrary inequalities justify more interventionist policies that would produce better and more equitable outcomes. Indeed, this divergence in views has been pronounced during the early stages of the financial crisis, where publics across different countries debated the need for government intervention to bail out ailing domestic industries. In particular, national polls fielded during the discussions of bailouts for firms in the financial and automotive sectors consistently showed that voters on the left and right differed in their views about the desirability of such interventions (Smith, 2014). ${ }^{8}$

In the same vein, if letting Greece default and drop out of the Eurozone is seen by citizens as as a choice between a market-based outcome and that of a (supra-)state intervention, we would expect a divide between left and right voters with regard to both the likely economic impact of a Grexit, as well as in level of support for such an outcome.

\section{Hypothesis 9 (Mechanism: Expected Grexit Impact) (a) Left-wing voters exhibit greater} belief that a Grexit would adversely affect the European economy; (b) Individuals that expect the Grexit to have a negative effect on the European economy are more likely to oppose the Grexit.

The mechanisms outlined above offer four different explanations for the striking significance of voters' left-right position in structuring the divide over the Grexit question. These alternative

\footnotetext{
${ }^{8}$ For example, according to surveys carried out in 2008 by ABC News/Washington Post and Los Angeles Times/Bloomberg News, $57 \%$ of Democrats supported the bailouts for the auto industry while $35 \%$ opposed it. The picture among self-described conservatives was almost the exact the opposite: $30 \%$ supported and $59 \%$ opposed the bailouts. Comparison of Democrats and Republicans reveals a similar picture. See (Smith, 2014) for a broader review of the evidence on the determinants of attitudes toward domestic bailouts.
} 
explanations also yield clear and testable predictions. In the next section we turn to assess the empirical support for each of the predictions.

\section{B. Testing the Key Explanations}

We begin by examining the two predictions derived from the first account centered on partisans' redistributive concerns. The top panel of Figure 5 presents the results pertaining to the two relevant hypotheses. As the graph on the left indicates, we find strong support for the first prediction $(\mathrm{H} 6 \mathrm{a})$, whereby left and right voters differ significantly in terms of their attitudes on questions of domestic redistribution. Voters on the far left have the greatest propensity to support redistributive measures aimed at reducing inequalities between the rich and the poor, and pro-redistribution attitudes decline steadily moving to the right on the ideological spectrum. In contrast, the graph on the top right offers no support to the second, and critical, prediction of the redistributive concerns explanation $(\mathrm{H} 6 b)$. We find that within each of the five groups across the left-right scale, support for the Grexit is almost identical among citizens that exhibit proand anti-redistribution attitudes. Put differently, attitudes on domestic redistribution account for almost none of the variation on the Grexit question. As the directed acyclic graph (DAG) in the center of the top panel indicates, the explanation that people's views on redistribution are the link between left-right ideology and attitudes on the Grexit fails the empirical test, as the the second link in the chain is not supported by the data.

Turning to the second explanation centered on an empathy gap, the evidence is again not supportive. Consistent with $H^{r}$ a, though only weakly, the left graph in the bottom panel of Figure 5 indicates that voters on the left exhibit slightly higher levels of empathy than voters on the right. Yet as the figure on the bottom right shows, once accounting for voters' position on the left-right scale, there is almost no difference in support for the Grexit between individuals with high and low levels of empathy. Thus, as the DAG in the bottom panel indicates, the second link of the causal chain is empirically unsubstantiated, allowing us also to discard this line of explanation. ${ }^{9}$

\footnotetext{
${ }^{9}$ For the first link in the logical chain we draw a dashed, bidirectional arrow since one might question in what
} 
direction the causal arrow should go: does ideology shape one's empathy, does empathy shape one's ideological disposition, or is there some factor further upstream that shapes both? In this case, given that the second link of the chain fails the empirical test, resolution of this question of directionality becomes a moot point in the context of our specific investigation. 
Figure 5: Investigation of Redistributive Concerns and Empathy Gap Mechanisms
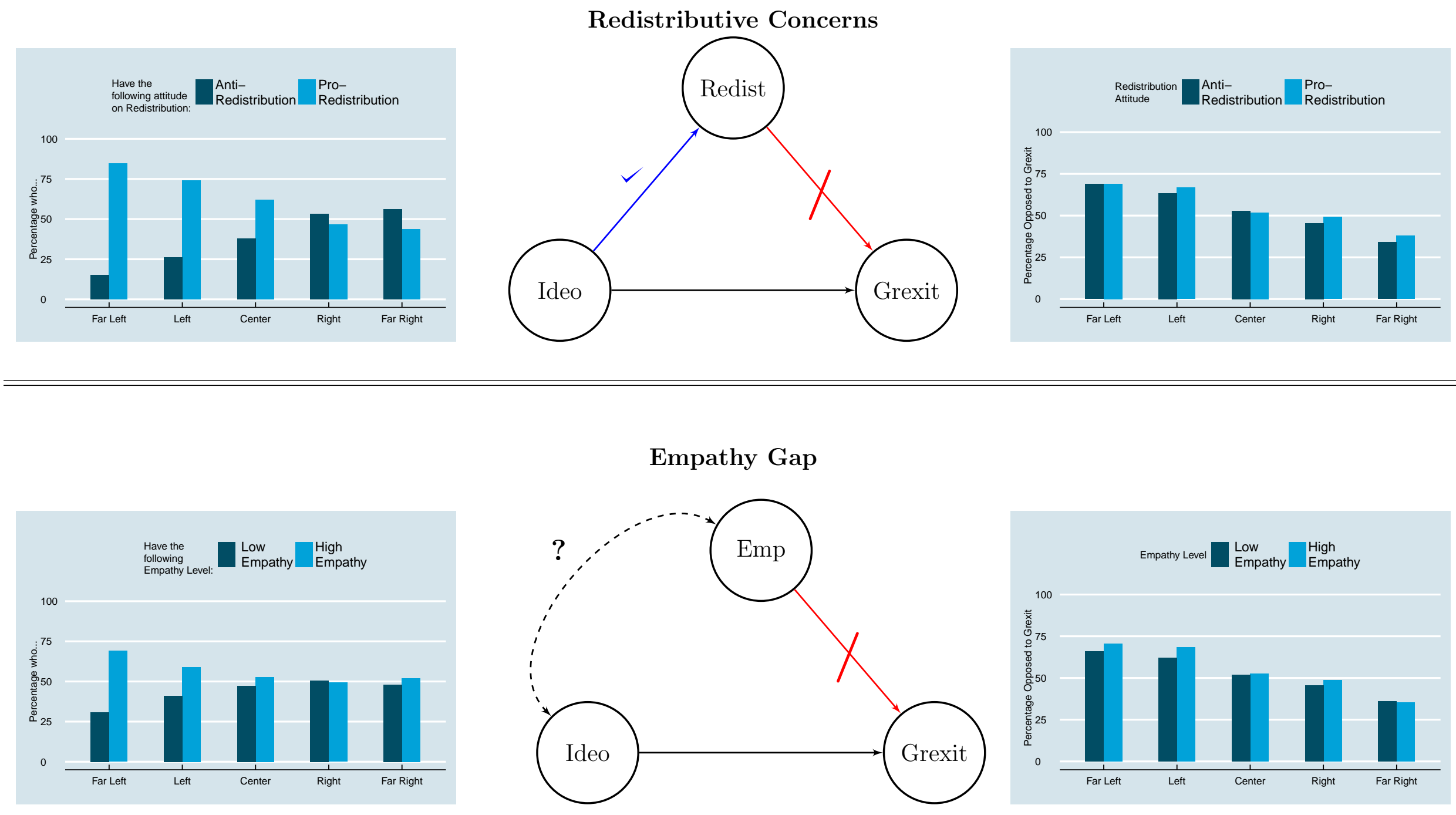
The top panel of Figure 6 shows the DAG and the corresponding graphs for the EU attitudes explanation. Hypothesis $8 a$ laid out the expectation that voters on the right are less supportive of the EU project, and hence more likely to see Greece defaulting and leaving the Eurozone as a good outcome. Yet as the figure on the left indicates, we find no clear evidence for the first claim. ${ }^{10}$ Instead, a seemingly idiosyncratic relationship between left-right ideology and EU attitudes emerges, with voters on the far left exhibiting similar attitudes toward the EU as voters on the right, both in terms of support and in degree of opposition, and voters in the center being most similar to voters on the far right. Thus, while we find a close link between pro-EU attitudes and opposition to the Grexit (right graph), the lack of a clear correspondence between left-right ideology and EU attitudes (left graph) suggests that attitudes on the EU do not provide a key explanation for the left-right divide over the Grexit.

Finally, we present the results pertaining to the economic beliefs explanation in the bottom panel of Figure 6. Here, we find strong support for both links of the chain. As the graph on the left indicates, we find a strong relationship between ideological position and beliefs about the impact that a Grexit is likely to exert on the European economy. Whereas a sizable plurality of voters on the left expect a Grexit to have adverse effects on the European economy, as we move rightward on the ideological scale we see these numbers shrink dramatically. This relationship is striking in its magnitude, and in our view, is far from obvious. At the same, we find that the share of voters who expect a Grexit to aid the European economy grows monotonically as one moves rightwards, reaching a plurality among those on the far right. With respect to the second - and perhaps more obviousprediction, the figure on the right indicates that people's beliefs about the economic effects of the Grexit are closely tied to their expressed support for this outcome. Opposition to the Grexit within each ideological segment is about three to five times higher among those who expect it to have adverse economic effects in Europe than those who hold the opposite view.

\footnotetext{
${ }^{10}$ As with the empathy mechanism, for the first link in this mechanism's chain we draw a dashed, bidirectional arrow since some upstream factor may be argued to lead to both ideology and EU attitudes, calling into question the precise directionality between these two variables. Yet in this case, we do not find a clear correlation between ideology and EU attitude, and thus resolution of this question of directionality becomes a moot point in the context of our specific investigation.
} 
In sum, we find strong evidence in support of the fourth account: left and right have strongly divergent views about what a Grexit's economic impact is likely to be, corresponding with very different patterns of support for letting Greece default and drop out of the currency union. 


\section{General EU Support}
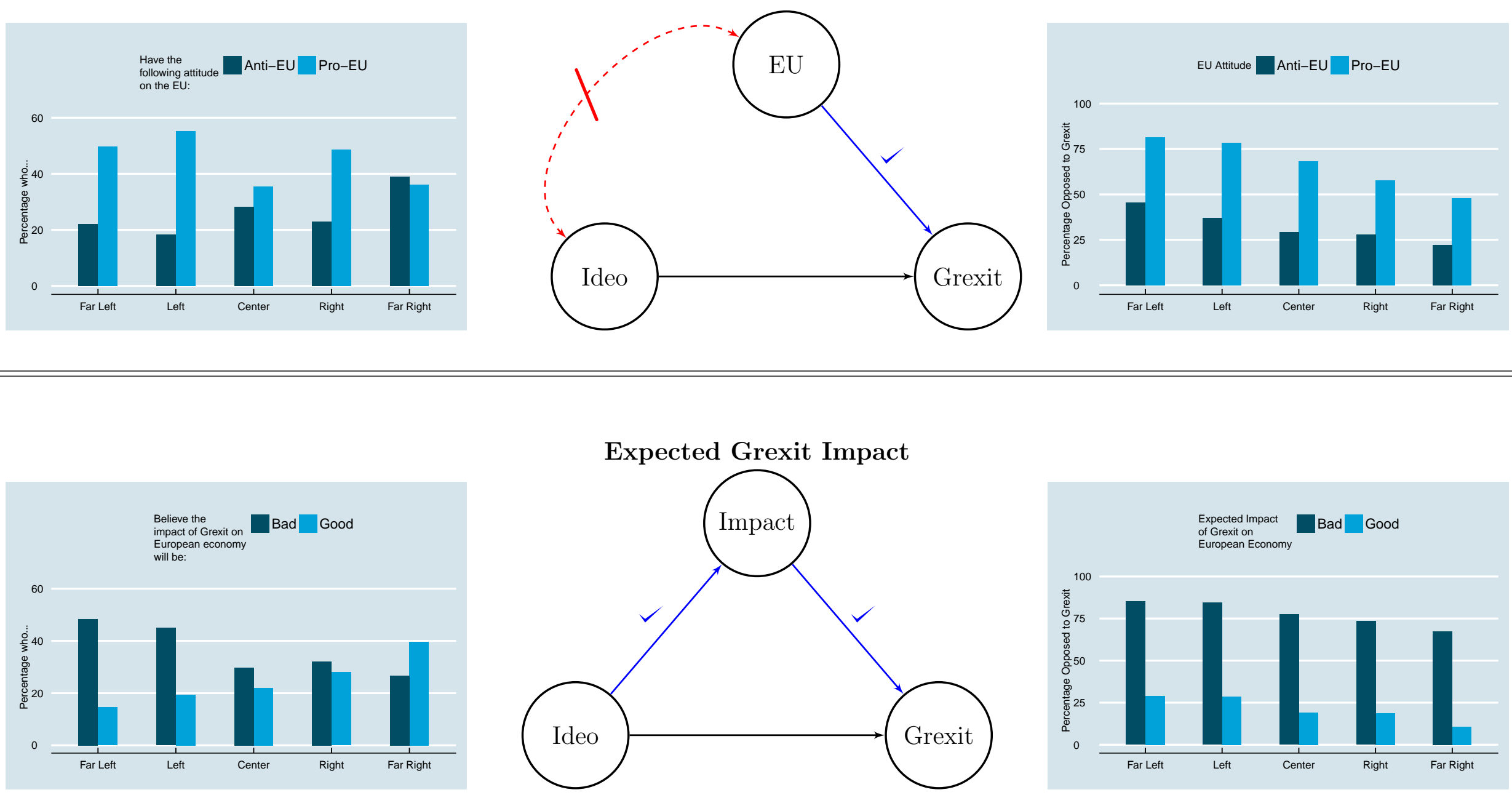
In Table 2, we examine whether these results hold up once we adjust for other covariates in a regression. The dependent variable in Models 1 and 2, which are linear probability models, is the respondent's position on the Grexit, whereby ' 1 ' represents opposition to the Grexit and ' 0 ' indicates support. Model 2 allows for a test of the second link in the chain for each potential mechanism. ${ }^{11}$ The dependent variables in Models 3-6 are the four potential mediating variables. Redistribution attitudes and empathy levels are binary, whereas EU support and expected Grexit impact are both 3-point variables. These models allow for tests of the first link in the chain for each potential mechanism. In all models, we include indicator variables for each of the ideological segments, with centrists as the baseline (omitted) category. All models also include country fixed effects and our battery of economic and demographic controls. ${ }^{12}$

Consistent with the patterns observed in the panels of graphs in Figures 5 and 6, we find a clear monotonic increase in opposition to the Grexit moving from right to left on ideological spectrum. When not including the mediators as regressors (i.e. Model 1), we find that being on the far left is associated with 30.6 percentage point increase in the probability of being opposed to the Grexit relative to counterparts at the far right, respectively. The results in Model 2 are also consistent with the graphs in Figures 5 and 6 . Neither redistribution attitudes nor empathy levels appear to explain attitudes toward the Grexit in statistically or substantively significant terms. In contrast, a pro-EU stance is associated with a 26 percentage-point increase in opposition to the Grexit relative to an anti-EU stance, and a positive perspective regarding the expected impact of a Grexit is associated with a roughly 50 percentage-point decrease in opposition to the Grexit relative to a negative perspective. ${ }^{13}$ In other words, the elimination

\footnotetext{
${ }^{11}$ We use linear probability models because of the ease of interpretation as compared to limited dependent variable models. In the appendix we also reestimate the same models using logit and probit models. The results are unchanged both substantively and statistically.

${ }^{12}$ These include: income (by quintile), an indicator for being employed, an indicator for having a public primary source of income, an indicator for having professional experience in the public sector, an indicator for having investments, an indicator for owning a home, an indicator for having a mortgage, education (with four categories), gender, age (with four categories), number of children, and an indicator for having voted in the most recent national election.

${ }^{13}$ The EU Support and Positive Expected Grexit Impact variables are 3-point variables. For the EU Support variable, 1 denotes pro-EU, -1 denotes anti-EU, and 0 denotes neutrality. For the Positive Expected Grexit Impact variable, 1 denotes belief that the Grexit will have a positive effect on the European economy, -1 denotes belief that the Grexit will have a negative effect on the European economy, and 0 denotes neutrality.
} 
of the second link in the chain for the redistribution and empathy mechanisms, as well as the confirmation of the second link in the chain for the EU and Grexit impact mechanisms, are corroborated in the regression results.

Furthermore, as in the graphs in Figures 6, regression Model 5 casts doubt on the first link of the chain in the EU mechanism. There do appear to be clear differences in levels of support for the EU among the different ideological segments. However, the relationship between ideology and EU support is irregular, and hence it seems unlikely that EU support is systematically mediating the monotonic relationship between ideology and opposition to the Grexit. In contrast, Model 6 demonstrates that positive expectations regarding the impact of a Grexit do increase monotonically moving from left to right on the ideological spectrum, thereby providing support for the economic beliefs explanation of the relationship between ideology and Grexit opposition.

Finally, to further explore the relative power of the competing explanations, Table 3 shows how regression results with Grexit opposition as the dependent variable vary as the potential mediators are added to the model. Relative to Model 1, which does not include any of the potential mediators as regressors, the ideology coefficients hardly change in Models 2-4, as the redistribution, empathy, and EU support variables are added. In contrast, in Model 5, when Grexit impact expectations are added, the ideology coefficients are substantially attenuated. Furthermore, the share of explained variation in the model triples as compared to the baseline level in Model 1. We see a similar pattern comparing Model 6 which includes all of the potential mediator variables other than the measure of the expected Grexit impact, and Model 7 which further adds the expected Grexit impact variable.

Overall comparing the results of the estimations with and without people's economic expectations highlights the same finding: the coefficients on the ideology variables shrink substantially and the overall fit of the model improves markedly when economic expectations are included. Recall, that in Model 1 which does not include the mediators, being on the far left is associated with 30.6 percentage point increase in the probability of being opposed to the Grexit relative to counterparts at the far right, respectively. But once economic expectations are added as a me- 
Table 2: Testing the Competing Mechanisms (Full Sample)

\begin{tabular}{|c|c|c|c|c|c|c|}
\hline & $\begin{array}{l}\text { Model } 1 \\
\text { Oppose } \\
\text { Grexit } \\
\text { (Binary) }\end{array}$ & $\begin{array}{l}\text { Model } 2 \\
\text { Oppose } \\
\text { Grexit } \\
\text { (Binary) }\end{array}$ & $\begin{array}{c}\text { Model } 3 \\
\text { Pro- } \\
\text { Redistribution } \\
\text { (Binary) }\end{array}$ & $\begin{array}{l}\text { Model } 4 \\
\text { High } \\
\text { Empathy } \\
\text { (Binary) }\end{array}$ & $\begin{array}{l}\text { Model } 5 \\
\text { EU } \\
\text { Support } \\
\text { (3-Point) }\end{array}$ & $\begin{array}{c}\text { Model } 6 \\
\text { Positive Expected } \\
\text { Grexit Impact } \\
\text { (3-Point) }\end{array}$ \\
\hline Far Left & $\begin{array}{l}0.128^{*} \\
(0.012)\end{array}$ & $\begin{array}{l}0.061^{*} \\
(0.011)\end{array}$ & $\begin{array}{l}0.220^{*} \\
(0.011)\end{array}$ & $\begin{array}{l}0.158^{*} \\
(0.012)\end{array}$ & $\begin{array}{l}0.111^{*} \\
(0.021)\end{array}$ & $\begin{array}{c}-0.188^{*} \\
(0.019)\end{array}$ \\
\hline Left & $\begin{array}{l}0.105^{*} \\
(0.013)\end{array}$ & $\begin{array}{l}0.049^{*} \\
(0.011)\end{array}$ & $\begin{array}{l}0.123^{*} \\
(0.012)\end{array}$ & $\begin{array}{l}0.061^{*} \\
(0.013)\end{array}$ & $\begin{array}{l}0.198^{*} \\
(0.020)\end{array}$ & $\begin{array}{c}-0.110^{*} \\
(0.019)\end{array}$ \\
\hline Right & $\begin{array}{c}-0.070^{*} \\
(0.013)\end{array}$ & $\begin{array}{c}-0.065^{*} \\
(0.012)\end{array}$ & $\begin{array}{c}-0.128^{*} \\
(0.013)\end{array}$ & $\begin{array}{c}-0.026^{*} \\
(0.013)\end{array}$ & $\begin{array}{l}0.107^{*} \\
(0.021)\end{array}$ & $\begin{array}{l}0.065^{*} \\
(0.020)\end{array}$ \\
\hline Far Right & $\begin{array}{c}-0.178^{*} \\
(0.014)\end{array}$ & $\begin{array}{c}-0.104^{*} \\
(0.012)\end{array}$ & $\begin{array}{c}-0.155^{*} \\
(0.014)\end{array}$ & $\begin{array}{c}0.010 \\
(0.014)\end{array}$ & $\begin{array}{c}-0.135^{*} \\
(0.024)\end{array}$ & $\begin{array}{l}0.218^{*} \\
(0.022)\end{array}$ \\
\hline Pro-Redistribution & & $\begin{array}{c}0.013 \\
(0.008)\end{array}$ & & & & \\
\hline High Empathy & & $\begin{array}{c}0.013 \\
(0.008)\end{array}$ & & & & \\
\hline EU Support & & $\begin{array}{l}0.130^{*} \\
(0.005)\end{array}$ & & & & \\
\hline Positive Expected Grexit Impact & & $\begin{array}{c}-0.254^{*} \\
(0.005)\end{array}$ & & & & \\
\hline $\begin{array}{l}\text { Economic, Demographic, } \\
\text { Additional Controls }\end{array}$ & $\checkmark$ & $\checkmark$ & $\checkmark$ & $\checkmark$ & $\checkmark$ & $\checkmark$ \\
\hline Country Fixed Effects & $\checkmark$ & $\checkmark$ & $\checkmark$ & $\checkmark$ & $\checkmark$ & $\checkmark$ \\
\hline $\mathrm{R}^{2}$ & 0.083 & 0.285 & 0.115 & 0.070 & 0.097 & 0.087 \\
\hline Adj. $R^{2}$ & 0.081 & 0.284 & 0.113 & 0.068 & 0.095 & 0.085 \\
\hline Num. obs. & 12839 & 12839 & 12839 & 12839 & 12839 & 12839 \\
\hline
\end{tabular}

${ }^{*} p<0.05$

Note: All models are linear regression models. Models 1-4 reported in this table are linear probability models, while the dependent variables in Models 5 and 6 take the values $-1,0$, and 1 . All regressions include the full, pooled sample and contain country fixed effects as well as the full battery of control variables. This includes: income level, employment status, whether primary income source is a public source, public sector experience, ownership of investments, home ownership, mortgage holdings, education, gender, age, number of children, and voting behavior. 
diator in Models 5 and 7 the estimated difference between far left and far right shrinks by about half to only 19.5 and 16.5 percentage points, respectively. Taken together, these results suggest that a sizable portion of the left-right difference in support for the Grexit can be accounted for by the divergent views about its likely economic impact, while the other three mechanisms offer limited explanatory power.

Table 3: Predictors of Opposition to the Grexit (Full Sample)

\begin{tabular}{|c|c|c|c|c|c|c|c|}
\hline & Model 1 & Model 2 & Model 3 & Model 4 & Model 5 & Model 6 & Model 7 \\
\hline Far Left & $\begin{array}{l}0.128^{*} \\
(0.012)\end{array}$ & $\begin{array}{l}0.124^{*} \\
(0.013)\end{array}$ & $\begin{array}{l}0.123^{*} \\
(0.013)\end{array}$ & $\begin{array}{l}0.109^{*} \\
(0.012)\end{array}$ & $\begin{array}{l}0.076^{*} \\
(0.011)\end{array}$ & $\begin{array}{l}0.100^{*} \\
(0.012)\end{array}$ & $\begin{array}{l}0.061^{*} \\
(0.011)\end{array}$ \\
\hline Left & $\begin{array}{l}0.105^{*} \\
(0.013)\end{array}$ & $\begin{array}{l}0.103^{*} \\
(0.013)\end{array}$ & $\begin{array}{l}0.104^{*} \\
(0.013)\end{array}$ & $\begin{array}{l}0.073^{*} \\
(0.012)\end{array}$ & $\begin{array}{l}0.075^{*} \\
(0.011)\end{array}$ & $\begin{array}{l}0.068^{*} \\
(0.012)\end{array}$ & $\begin{array}{l}0.049^{*} \\
(0.011)\end{array}$ \\
\hline Right & $\begin{array}{c}-0.070^{*} \\
(0.013)\end{array}$ & $\begin{array}{c}-0.068^{*} \\
(0.013)\end{array}$ & $\begin{array}{c}-0.069^{*} \\
(0.013)\end{array}$ & $\begin{array}{c}-0.087^{*} \\
(0.013)\end{array}$ & $\begin{array}{c}-0.052^{*} \\
(0.012)\end{array}$ & $\begin{array}{c}-0.083^{*} \\
(0.013)\end{array}$ & $\begin{array}{c}-0.065^{*} \\
(0.012)\end{array}$ \\
\hline Far Right & $\begin{array}{c}-0.178^{*} \\
(0.014)\end{array}$ & $\begin{array}{c}-0.176^{*} \\
(0.014)\end{array}$ & $\begin{array}{c}-0.179^{*} \\
(0.014)\end{array}$ & $\begin{array}{c}-0.156^{*} \\
(0.014)\end{array}$ & $\begin{array}{c}-0.119^{*} \\
(0.013)\end{array}$ & $\begin{array}{c}-0.152^{*} \\
(0.014)\end{array}$ & $\begin{array}{c}-0.104^{*} \\
(0.012)\end{array}$ \\
\hline Pro-Redistribution & & $\checkmark$ & & & & $\checkmark$ & $\checkmark$ \\
\hline High Empathy & & & $\checkmark$ & & & $\checkmark$ & $\checkmark$ \\
\hline EU Support & & & & $\checkmark$ & & $\checkmark$ & $\checkmark$ \\
\hline Positive Expected Grexit Impact & & & & & $\checkmark$ & & $\checkmark$ \\
\hline $\begin{array}{l}\text { Economic, Demographic, } \\
\text { Additional Controls }\end{array}$ & $\checkmark$ & $\checkmark$ & $\checkmark$ & $\checkmark$ & $\checkmark$ & $\checkmark$ & $\checkmark$ \\
\hline Country Fixed Effects & $\checkmark$ & $\checkmark$ & $\checkmark$ & $\checkmark$ & $\checkmark$ & $\checkmark$ & $\checkmark$ \\
\hline $\mathrm{R}^{2}$ & 0.083 & 0.083 & 0.083 & 0.149 & 0.245 & 0.150 & 0.285 \\
\hline Adj. $R^{2}$ & 0.081 & 0.081 & 0.081 & 0.147 & 0.243 & 0.148 & 0.284 \\
\hline Num. obs. & 12839 & 12839 & 12839 & 12839 & 12839 & 12839 & 12839 \\
\hline
\end{tabular}




\section{Why do the Left and Right Hold Differing Expectations Regarding the}

\section{IMPACT OF A GREXIT?}

So far, our results suggest that pronounced left-right divide characterizes preferences over the Grexit issue and that this relationship reflects to a large extent divergent expectations about the economic impact of this outcome. This begs the question why individuals on the left and the right have such diverging expectations about how a Grexit would affect the economy?

One possibility why the left and right have different expectations about the likely impact of the Grexit on the European economy mirror differences in their beliefs in a free-market approach. Avoiding the Grexit so far required significant political intervention in markets in the form or bailouts and various monetary policy efforts. Therefore, those who hold a free-market ideology should oppose efforts to keep Greece in the Euro despite the strong pressure of free markets towards a default. In contrast, individuals believing that governments should intervene and "correct" outcomes resulting from free market forces should support policy measures designed to avoid the Grexit. To the extent that the left and the right differ in terms of their economic ideology this might explain differences in expectations about the economic impact of the Grexit. To evaluate this idea, we regress opinions about the expected Grexit impact on voters' left-right ideology, a measure of their free-market ideology, and the interaction between the two as well as the full set of covariates from the baseline model. We use the variable "Free-Market Ideology", which is based on a 9-point score computed from two survey items that measure the extent to which a respondent's economic ideology emphasizes the importance of free-market forces, versus the importance of government intervention. ${ }^{14}$

Table 4 reports the results. We find that among every ideological segment-except for the center, for reasons that remain unclear - those who are more of a free-marketeer are more likely

\footnotetext{
${ }^{14}$ The 9-point scale (0-8) is constructed based on the combination of answers to two questions: the redistribution question described earlier and a more general question on government intervention. The question wording for the more general intervention question was: "Next, we would like you to think more broadly about the purposes of government. Where would you rate yourself on a scale of 1 to 5 , where 1 means you think the government should do only those things necessary to provide the most basic government functions, and 5 means you think the government should take active steps in every area it can to try and improve the lives of its citizens? You may use any number from 1 to 5." The value of the respondents' answers to both questions were added and then subtracted from 10. As a result, 0 correspondents to weak free-market ideology (i.e. strong belief in government intervention) and 8 corresponds to strong free-market ideology.
} 
to view the Grexit as having a positive effect on the European economy. This can also be seen graphically in Figure 7, which presents for each ideological segment a LOESS fit of individuals' predicted expectation regarding the Grexit impact as a function of free-market ideology. ${ }^{15}$ Figure 7 presents fairly clear graphical evidence of two phenomena. First, the LOESS lines' centers of mass shift upward moving left to right on the ideological spectrum, demonstrating as we already saw earlier that average expectations regarding the impact of Grexit are more positive on the right and more negative on the left. Second, Figure 7 also shows that, within each ideological segment - again, except for the center - a stronger free-market attitude is associated with more positive Grexit impact expectations. Finally, Figure 8 shows that the distribution of free-market ideology increasingly shifts upwards moving from left to right on the ideological spectrum, as would be expected.

Taken together, the graphical and regression evidence above suggests that the difference between left and right in expectations about the likely impact that a Grexit would exert on the European economy is in part a result of the fact that a Grexit would be perceived by citizens to be the outcome of the unperturbed operation of the free market. Conversely, prevention of a Grexit is seen as the result of government intervention, exhibited most clearly by the European governments' bailout negotiations. For those citizens who believe free-market dynamics are more likely to lead to positive economic outcomes, who are disproportionately on the right, a Grexit should then be expected to have positive economic consequences. One might argue whether this view is justified, but nonetheless it appears to play an important role.

\footnotetext{
${ }^{15}$ The expected Grexit impact predicted values are taken from the regression Model 2 in Table 4
} 
Table 4: Predictors of Expectations regarding Impact of Grexit on European Economy (Full Sample)

\begin{tabular}{|c|c|c|}
\hline & Model 1 & Model 2 \\
\hline Far Left & $\begin{array}{c}-0.188^{*} \\
(0.019)\end{array}$ & $\begin{array}{r}-0.245^{*} \\
(0.025)\end{array}$ \\
\hline Left & $\begin{array}{c}-0.110^{*} \\
(0.019)\end{array}$ & $\begin{array}{r}-0.168^{*} \\
(0.028)\end{array}$ \\
\hline Right & $\begin{array}{l}0.065^{*} \\
(0.020)\end{array}$ & $\begin{array}{c}0.016 \\
(0.033)\end{array}$ \\
\hline Far Right & $\begin{array}{l}0.218^{*} \\
(0.022)\end{array}$ & $\begin{array}{l}0.129^{*} \\
(0.035)\end{array}$ \\
\hline Free-Market-Ideology (0-8) & & $\begin{array}{l}-0.003 \\
(0.007)\end{array}$ \\
\hline Far Left * Free-Market-Ideology & & $\begin{array}{l}0.044^{*} \\
(0.012)\end{array}$ \\
\hline Left $*$ Free-Market-Ideology & & $\begin{array}{l}0.033^{*} \\
(0.012)\end{array}$ \\
\hline Right $*$ Free-Market-Ideology & & $\begin{array}{c}0.020 \\
(0.011)\end{array}$ \\
\hline Far Right * Free-Market-Ideology & & $\begin{array}{l}0.035^{*} \\
(0.011)\end{array}$ \\
\hline $\begin{array}{l}\text { Economic, Demographic, } \\
\text { Additional Controls }\end{array}$ & $\checkmark$ & $\checkmark$ \\
\hline Country Fixed Effects & $\checkmark$ & $\checkmark$ \\
\hline $\mathrm{R}^{2}$ & 0.087 & 0.090 \\
\hline Adj. $R^{2}$ & 0.085 & 0.088 \\
\hline Num. obs. & 12839 & 12839 \\
\hline
\end{tabular}

${ }^{*} p<0.05$

Note: Both models are linear regression models. The dependent variable takes the values -1 (negative expectations), 0 (neutral expectations, and 1 (positive expectations). Regressions include the full, pooled sample and contain country fixed effects as well as the full battery of control variables. 
Figure 7: LOESS Fits: Expected Economic Impact of Grexit

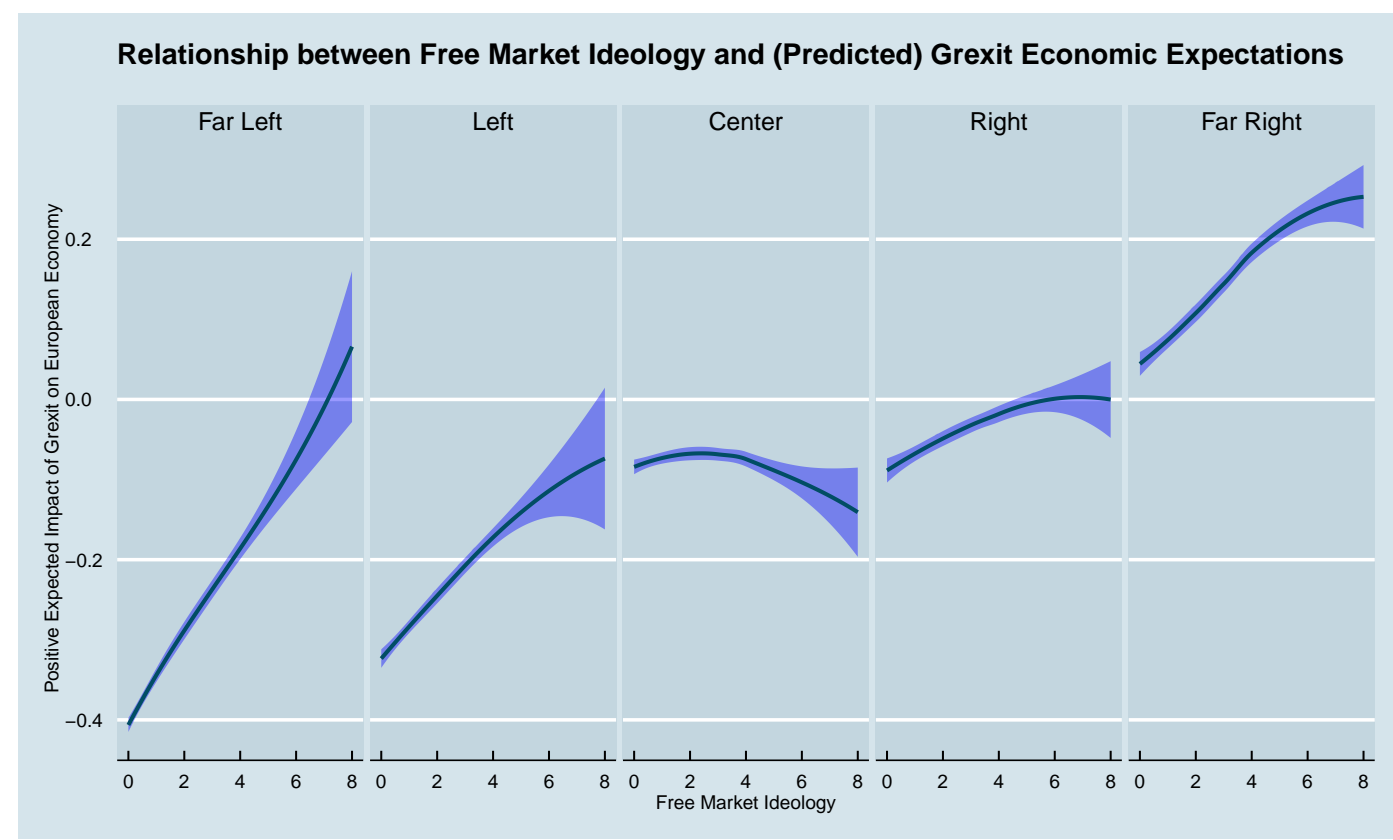

Note: This plot shows LOESS lines (with 95\% confidence bands) of predicted Grexit economic impact expectations fitted on the free market ideology variable, for each of the left-right ideological bins. The predictions of Grexit economic impact expectations are extracted from the regression reported by Model 2 in Table 4.

Figure 8: Distribution of Free Market Ideology

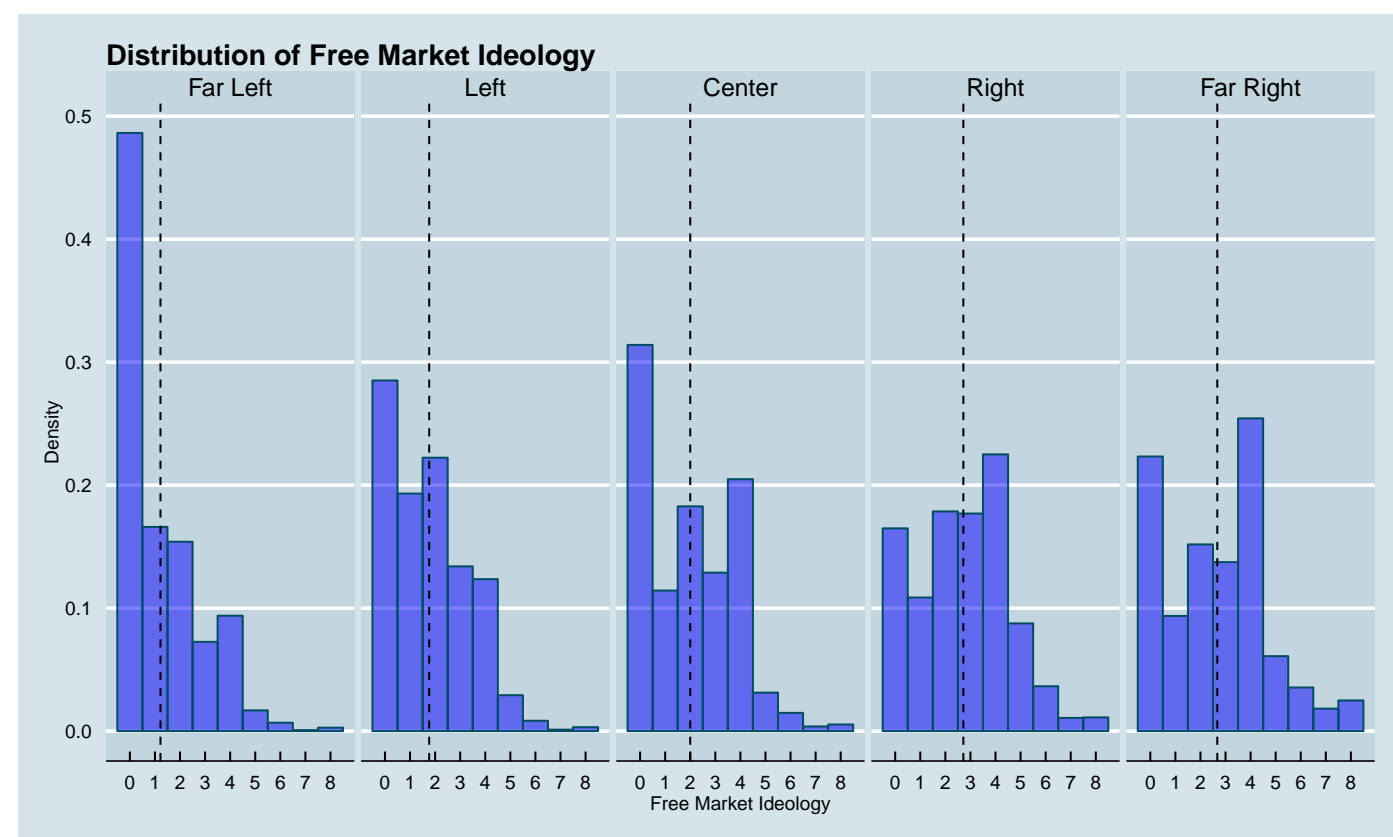

Note: This plot includes, for each left-right ideological bin, a histogram showing the distribution of free-market ideology. The dashed vertical lines denote the mean level of free market ideology for each left-right bin. 


\section{Robustness}

We conducted various checks to corroborate the robustness of the findings. Here we briefly summarize these checks, which are presented in the appendix. In particular, we find that our regression results explaining Grexit opposition as the dependent variable are similar when using logit and probit models as opposed to our linear probability models (Table C.9), and our full set of results hold for each country individually (Tables C.3, C.4, C.5, and C.6), when using the 5-point ordinal version of the Grexit opposition variable (Tables C.7 and C.8), when ideology is measured using different bins on the 11-point scale ${ }^{16}$ (Tables C.11, C.12, and C.13), or when instead of ideology we use respondents' party identification and code the parties based on the 2014 Chapel Hill Expert Survey left-right party placements (Tables C.14, C.15, C.16, and C.17). We also find that our results are robust to various other model specifications including the addition of pairwise interactions of all covariates (Table C.10) or when using a using a formal causal mediation results (Tables C.18 and C.19).

In addition, a possible alternative explanation for the relationship between left-right ideology and opposition to the Grexit relates to the fact that the Greek government involved in the bailout negotiations was controlled by a left-wing ruling party, SYRIZA. As a result, it is possible that higher support for a Grexit among right-wing European voters was the result of ideological antipathy directed toward the left-wing Greek government. While we do not have data to directly test this possibility, we perform indirect tests that cast doubt on this explanation being the crucial link between left-right ideology and attitudes toward the Grexit. In particular, we re-specify a linear probability model that regresses Grexit opposition on the ideology bins; the full battery of economic, social, and demographic controls; a measure of political knowledge about the European debt crisis; and interactions between the ideology bins and that knowledge measure. ${ }^{17}$ If right-wing support for a Grexit is motivated by antipathy toward the left-wing

\footnotetext{
${ }^{16}$ The alternative coding of the ideology bins is as follows: Far Left (0-1), Left (2-3), Center (4-6), Right (7-8), Far Right (9-10).

${ }^{17}$ To construct this knowledge measure, respondents were presented with a list of European countries and asked to identify which of the countries received financial bailout assistance. Respondents were given +1 points for all correct selections and -1 points for all incorrect selections. In the regression specification described here, the variable was put into binary form, using the mean as the cut point, thus serving as an indicator for high knowledge.
} 
Greek government, then right-wing voters had to be aware of the fact that the Greek government was in fact led by a left-wing party. Furthermore, those voters who are more knowledgeable about the European debt crisis are also more likely to be familiar with SYRIZA's left-wing status. It then follows that the left-right divide on the Grexit question should be significantly less pronounced or even non-existent among less knowledgeable voters, in which case the interactions terms in the re-specified regression should be substantively large and statistically significant. However, as reported in Table C.20 in the appendix, we do not find such evidence, either in the pooled sample or for each country individually. In sum, though we cannot completely rule out the relevance of this explanation, our evidence suggests that if it is occurring, it exhibits only a small effect and is clearly not driving the massive left-right divide on the Grexit question.

\section{Discussion}

In the early years of the European Union project, much of the scholarly discussion centered on the question of whether EU integration will be a political dimension that cross-cuts the traditional cleavages, or whether over time it will submerge into the dominant left-right divide. Indeed, a range of analyses examining data from the 1990s found that EU integration topic cleaved the publics primarily along a center-extremes division. Whereas voters on the far left and far right expressed vocal opposition to further integration, voters in the center of the ideological spectrum tended to embrace the EU project (Hix and Lord, 1997; Taggart, 1998; Hooghe et al., 2002). Yet this pattern is very different from what we observe with respect to the Grexit question, in which the overwhelming cleavage among European publics is the left-right ideological divide. This submerging has major potential implications for the EU project as a whole. As long as the EU issue pitted the center versus the extremes, it was fairly clear that the bulk of voters in Europe were firmly within the pro-EU camp. However, the shift toward a new politics whereby maintaining the EU whole becomes a divisive issue between left and right, means that the pro and anti EU camps could be far more evenly split than before, with the distinct possibility of the EU skeptics increasingly gaining the upper hand. 
Another potentially important consequence of EU integration becoming a left-right issue is the possibility of cross-country political alliances becoming increasingly prevalent. With the EU turning into both an issue of debate and a political entity that ties together voters from the region's different nations (e.g. elections to the European Parliament), the rationale for linking similar ideological forces operating in different countries is bound to grow. This also implies that the future of European integration will increasingly depend on the ideological congruence of governments. Indeed, the debate over the Grexit and the austerity program brought together forces on the far Left from Greece's Syriza party with those of the Spanish Podemos. At the same time, far right parties from seven countries - including France, Italy and the Netherlands - coalesced to act together against what they described as the creation of a "European Superstate". Whether this is a one-off event remains to be seen, but our findings suggest that they may potentially form part of a more substantial shift in the ideological cleavage that underlies the European policy space.

One could argue, however, that the debate over the Grexit involved fairly complex issues and that only few will have invested the necessary time and effort to gain a deeper understanding of the issue. As the literature on public opinion suggests, in circumstances of facing complex matters, citizens are more likely to seek informational shortcuts that allow them to figure out what position to take on a given matter thereby saving the costs of acquiring encyclopedic knowledge and gaining subject-specific expertise. As a consequence, citizens may have used ideological signals as such a shortcut for placing themselves in the debate. This means that the pronounced ideological cleavage could ultimately reflect the complexity of the issue. However, whether a similar dynamic will or will not occur with respect to other issues in EU politics which people find simpler remains an open question.

As noted, our analysis indicates that the divisions between left and right over the Grexit are not a result of disagreements over redistributive politics. Rather, they reflect profoundly different expectations about the Grexit's likely economic effects. We present some evidence that these expectations are borne from views about the outcome that represents the operation of the free market. The right, much more skeptical of the effects of government intervention, 
opposes a Grexit that it sees as going against the dictates of market forces and as such, likely to produce economically inferior outcomes. In contrast, the left is more accepting of intervention aimed at avoiding a potential economic calamity, and believes such interventions will yield better outcomes. The phenomenon of divergent sociotropic beliefs about the economic consequences of policy choices has been largely ignored in the context of international economics. Our analysis suggests that it may offer a fruitful avenue for future research.

\section{REFERENCES}

Baker, A. (2005). Who Wants to Globalize? Consumer Tastes and Labor Markets in a Theory of Trade Policy Beliefs, American Journal of Political Science 49(4): 924-938.

Bearce, D. H. and Tuxhorn, K.-L. (2015). When are monetary policy preferences egocentric? evidence from american surveys and an experiment, American Journal of Political Science forthcoming.

Bechtel, M. M., Bernauer, T. and Meyer, R. (2012). The Green Side of Protectionism: Environmental Concerns and Three Facets of Trade Policy Preferences, Review of International Political Economy 19(5): 837-866.

Gabel, M. and Hix, S. (2002). "defining the eu political space: An empirical study of the european elections manifestos, 1979-1999", Comparative Political Studies 35(8): 934-964.

Gabel, M. and Hix, S. (2005). Understanding public support for british membership of the single currency, Political Studies 53(1): 65-81.

Gabel, M. J. (1998). Economic Integration and Mass Politics: Market Liberalization and Public Attitudes in the European Union, American Journal of Political Science 42(3): 936-953.

Hainmueller, J. and Hiscox, M. J. (2006). Learning to Love Globalization: Education and Individual Attitudes toward International Trade, International Organization 60(2): 469-498.

Hix, S. (1999). Dimensions and alignments in european union politics: Cognitive constraints and partisan responses, European Journal of Political Research 35(1): 69-106.

Hix, S. and Lord, C. (1997). Political Parties in the European Union, Palgrave Macmillan, London.

Hoffman, M. E. (2009). What Explains Attitudes across US Trade Policies?, Public Choice 138(3-4): 447-460.

Hooghe, L. and Marks, G. (2008). A postfunctionalist theory of european integration: From permissive consensus to constraining dissensus, British Journal of Political Science 39(1): 1-23.

Hooghe, L., Marks, G. and Wilson, C. (2002). Does Left/Right Structure Party Positions on European Integration?, Comparative Political Studies 35(8): 965-989.

Kaltenthaler, K. C., Gelleny, R. D. and Ceccoli, S. J. (2004). Explaining citizen support for trade liberalization, International Studies Quarterly 84(4): 829-851.

Markowski, R. and Tucker, J. A. (2005). Pocketbooks, Politics, and Parties: The 2003 Polish Referendum on EU Membership, Electoral Studies 24(3): 409-433.

Milner, H. V. and Judkins, B. (2004). Partisanship, Trade Policy, and Globalization: Is There a Left-Right Divide on Trade Policy?, International Studies Quarterly 48(1): 95-120.

Milner, H. V. and Tingley, D. H. (2011). Who supports global economic engagement? the sources of preferences in american foreign economic policy, International Organization 65(1): 37-68. 
Naoi, M. and Kume, I. (2011). Explaining mass support for agricultural protectionism: Evidence from a survey experiment during the global recession, International Organization 65(3): 771-795.

Noël, A. and Thérien, J.-P. (2008). Left and Right in Global Politics, Cambridge University Press, Cambridge.

O'Rourke, K. H. and Sinnott, R. (2001). The determinants of individual trade policy preferences: International survey evidence, Brookings Trade Forum pp. 157-196.

Padoan, P. C. (1997). Regional agreements as clubs, the european case, in E. L. Mansfield and H. V. Milner (eds), The Political Economy of Regionalism, Columbia University Press, New York, pp. 107-133.

Padoan, P. C. (2004). Emu as an evolutionary process, in G. Eusepi and F. Schneider (eds), Changing Institutions in the European Union: A Public Choice Perspective, Edward Elgar, Cheltenham, UK, pp. 105-127.

Scheve, K. F. and Slaughter, M. J. (2001). Labor market competition and individual preferences over immigration policy, Review of Economics and Statistics 83(1): 133-145.

Smith, M. G. (2014). Three Essays on the Political Economy of Corporate Bailouts, PhD thesis, Columbia University.

Taggart, P. (1998). A touchstone of dissent: Euroscepticism in contemporary western european party systems, European Journal of Political Research 33(3): 363-388.

Therien, J.-P. and Noël, A. (2000). Political parties and foreign aid, American Political Science Review 94(1): 151-162. 


\section{Supporting Information Appendix (Not for Publication) \\ Appendix A: SuRvey}

\section{A. Survey}

Our survey was fielded in May 2015. Respondents were recruited by Respondi, an international survey firm.

The following tables show the demographic and ideological margins of the sample.

Table A.1: Gender Distribution by Country

\begin{tabular}{rrr}
\hline & Male & Female \\
\hline France & $45 \%$ & $55 \%$ \\
Italy & $46 \%$ & $54 \%$ \\
Spain & $54 \%$ & $46 \%$ \\
United Kingdom & $44 \%$ & $56 \%$ \\
\hline
\end{tabular}

Table A.2: Age Distribution by Country

\begin{tabular}{rrrrrrr}
\hline & $<=29$ & $30-39$ & $40-49$ & $50-59$ & $60-69$ & $70+$ \\
\hline France & $29 \%$ & $19 \%$ & $20 \%$ & $16 \%$ & $12 \%$ & $4 \%$ \\
Italy & $19 \%$ & $25 \%$ & $25 \%$ & $20 \%$ & $12 \%$ & $0 \%$ \\
Spain & $20 \%$ & $24 \%$ & $27 \%$ & $20 \%$ & $8 \%$ & $0 \%$ \\
United Kingdom & $11 \%$ & $16 \%$ & $19 \%$ & $25 \%$ & $24 \%$ & $5 \%$ \\
\hline
\end{tabular}

Table A.3: Education Distribution by Country

\begin{tabular}{rrrrr}
\hline & Less than HS & HS Degree & BA Degree & Graduate Degree \\
\hline France & $9 \%$ & $66 \%$ & $9 \%$ & $16 \%$ \\
Italy & $12 \%$ & $51 \%$ & $12 \%$ & $24 \%$ \\
Spain & $16 \%$ & $35 \%$ & $20 \%$ & $29 \%$ \\
United Kingdom & $24 \%$ & $49 \%$ & $19 \%$ & $8 \%$ \\
\hline
\end{tabular}


Table A.4: Sample Ideological Distribution by Country (11-point)

\begin{tabular}{lccccccccccc}
\hline & 0 & 1 & 2 & 3 & 4 & 5 & 6 & 7 & 8 & 9 & 10 \\
\hline France & $6 \%$ & $3 \%$ & $7 \%$ & $8 \%$ & $7 \%$ & $29 \%$ & $9 \%$ & $11 \%$ & $8 \%$ & $4 \%$ & $7 \%$ \\
Italy & $6 \%$ & $5 \%$ & $8 \%$ & $10 \%$ & $9 \%$ & $27 \%$ & $9 \%$ & $9 \%$ & $7 \%$ & $4 \%$ & $5 \%$ \\
Spain & $8 \%$ & $7 \%$ & $13 \%$ & $15 \%$ & $10 \%$ & $26 \%$ & $8 \%$ & $6 \%$ & $4 \%$ & $1 \%$ & $1 \%$ \\
United Kingdom & $3 \%$ & $3 \%$ & $6 \%$ & $9 \%$ & $8 \%$ & $38 \%$ & $9 \%$ & $11 \%$ & $7 \%$ & $4 \%$ & $3 \%$ \\
\hline
\end{tabular}

Table A.5: Sample Ideological Distribution by Country (5-Point)

\begin{tabular}{lccccc}
\hline & Far Left & Left & Center & Right & Far Right \\
\hline France & $16 \%$ & $16 \%$ & $29 \%$ & $20 \%$ & $20 \%$ \\
Italy & $19 \%$ & $19 \%$ & $27 \%$ & $18 \%$ & $16 \%$ \\
Spain & $29 \%$ & $25 \%$ & $26 \%$ & $14 \%$ & $6 \%$ \\
United Kingdom & $11 \%$ & $17 \%$ & $38 \%$ & $20 \%$ & $14 \%$ \\
\hline
\end{tabular}




\section{Appendix B: VARiable Definition}

Primary Outcome Variable:

- Opposition to Grexit: Opposition to Grexit; binary version used in analysis with 1 indicating opposition to Grexit and 0 corresponding to favouring Grexit, where opposition/support was dichotomized using two questions. First question wording: "Some people would like Greece to exit the Eurozone (i.e. use a currency other than the Euro). Others prefer Greece to remain in the Eurozone (i.e. keep the Euro as its currency). Where do you stand on this issue? Do you favour or oppose a Greek exit from the Eurozone?" Answer categories: 1="Strongly favour", $2=$ "Favour", $3=$ "Neither favour nor oppose", 4="Oppose", 5="Strongly oppose." Follow-question for respondents choosing "Neither favour nor oppose": "If you had to decide, would you say you favour or oppose a Greek exit from the Eurozone?" Answer categories: 1="Favour", 2="Oppose."

Covariates:

- Ideology: Self-reported placement on left-right ideology scale. Question wording: "In politics people often talk of 'left' and 'right'. On this scale from 0 (left) to 10 (right), where would you classify your own political views?"

- Household Income: Self-reported monthly household income. Answer categories are the ten population household income deciles, which vary by country.

- Employed: Self-reported employment status; binary version used in analysis with 1 indicating employment as either a paid employee or self-employed, and 0 corresponding to any other answer choice. Question wording: "Which of these options best describes your situation (in the last seven days)?" Answer categories: 1="Paid employee (including temporary leave of absence due to maternity/paternity, accident, illness or vacation)", 2="Self-employed (e.g. freelancer, independent contractor, or family-owned business), $3=$ "Student (excluding employer-sponsored education), 4="Unemployed, actively searching for a job", $5=$ "Unemployed, not actively searching", 6="Chronic illness or permanent disability", 7="Retired", 8="Working at home, caring for children or others."

- Public Income Source: Self-reported indicator for whether a respondent's primary income source is a type of public source; binary version used in analysis where 1 indicates pensions, unemployment/redundancy benefit, or any other social benefits or grants constituting the respondent's main source of household income, and 0 otherwise. Question wording: "Please consider the income of all household members and any income which may be received by the household as a whole. What is the main source of income in your household?" Answer categories: 1="Wages or salaries", 2="Income from self-employment (excluding farming)", 3="Income from farming", $4=$ "Pensions", 5="Unemployment/redundancy benefit", 6="Any other social benefits for grants", $7=$ "Income from investments, savings, etc.", 8="Income from other sources."

- Public Sector Experience: Self-reported indicator for respondent's past or present public sector experience. Question wording: "Do you currently or have you ever worked for the government in a full-time public sector job?" Answer categories: $0=$ "No", 1="Yes."

- Investments: Self-reported indicator for whether or not respondent has money invested. Question wording: "Do you currently have money invested in stocks, bonds, mutual funds, money market funds or other listed securities?" Answer categories: $0=$ "No", $1=$ "Yes."

- Own Home: Self-reported indicator for current or planned home ownership; binary version used in analysis where 1 indicates current or planned home ownership. Question wording: "Do you/Does 
your family own your home/apartment, pay rent, or have other arrangements?" Answer categories: $1=$ "Own or are buying", $2=$ "Pay rent", $3=$ "Other."

- Mortgage: Self-reported indicator for whether or not respondent has a mortgage. Question wording: "Do you have a mortgage?" Answer categories: 0="No", 1="Yes."

- Education: Self-reported level of education. Answer categories were customized to each country's educational system, and answers were then mapped onto the International Standard Classification of Education (ISCED) 2011 scale, which measures education on a scale from 0 to 8 . For analysis, this scale was mapped onto a set of four categories equivalent in the American system to: (1) less than a high school degree; (2) high school degree; (3) bachelor's degree; and (4) graduate degree.

- Children: Self-reported number of children.

- Voted: Self-reported indicator for whether or not the respondent voted in the most recent national election.

- Pro-Redistribution: Measures whether the respondent is relatively in favor of or opposed to governmental redistribution. Binary version used in analysis, where 1 indicates redistribution preferences that are are greater (i.e. more in favor of redistribution) than the mean and 0 corresponds to redistribution preferences that are lower than the mean. Question wording: "Some people think that the income differences between the rich and the poor ought to be reduced, perhaps by raising the taxes of wealthy families or by giving income assistance to the poor. Others think that the government should not concern itself with reducing this income difference between the rich and the poor. Where would you rate yourself on a scale of 1 to 5 , where 1 means that the government should reduce the income differences between rich and poor, and 5 means that the government should not concern itself with reducing income differences? What score between 1 and 5 comes closest to the way you feel?"

- High Empathy: Measures whether the respondent registers a relatively high level of empathetic concern. Binary version used in analysis, where 1 indicates empathetic concern that is higher (i.e. more empathetic) than the mean and 0 corresponds to empathetic concern that is lower than the mean. Empathetic concern is measured using the combination of responses to two questions. Wording of questions: "On a scale from 1 (does NOT describe you well) to 5 (describes you well) how would you rate the following statements? [1] I am often touched by the things that I see happen. [2] When I see someone being taken advantage of, I feel kind of protective toward them."

- EU Support: Measures whether the respondent believes his/her country's membership in the European Union is a good thing or a bad thing. A 3-point version is used for analysis, where 1 indicates belief in the EU membership being good, -1 corresponding to belief in EU membership being bad, and 0 corresponding to neutrality. Question wording: "Generally speaking, do you think that the United Kingdom's membership of the European Union is...?" Answer categories: $1=$ "A very good thing", 2="A good thing", $3=$ "Neither good nor bad", 4="A bad thing", $5=$ "A very bad thing." Follow-up question for respondents choosing "Neither good nor bad": "If you had to decide, would you lean toward saying that the United Kingdom's membership of the European Union is...?" Answer categories: 1="A good thing", 2="A bad thing."

- Expected Grexit Impact: Measures the respondent's belief in whether Grexit would be good or bad for the European economy. A 3-point version is used for analysis, with -1 indicating belief that Grexit would be bad for the European economy, 0 corresponding to belief that Grexit would have a neutral effect on the European economy, and 1 indicating belief that Grexit would be 
good for the European economy. Question wording: "Do you think that a Greek exit from the Eurozone would have a positive or negative impact on the European economy?" Answer categories: 1="Very positive", 2="Positive", 3="Neutral", 4="Negative", 5="Very negative."

- Free-Market Ideology: Measures extent to which respondent's economic ideology emphasizes the importance of free-market forces, versus the importance of government intervention. Variable is a 9-point scale (0-8), constructed based on the combination of answers to two questions: the redistribution question described above and a more general question on government intervention. Question wording for the more general intervention question: "Next, we would like you to think more broadly about the purposes of government. Where would you rate yourself on a scale of 1 to 5 , where 1 means you think the government should do only those things necessary to provide the most basic government functions, and 5 means you think the government should take active steps in every area it can to try and improve the lives of its citizens? You may use any number from 1 to 5." The value of the respondents' answers to both questions were added and then subtracted from 10. As a result, 0 correspondents to weak free-market ideology (i.e. strong belief in government intervention) and 8 corresponds to strong free-market ideology.

- Political Knowledge of the European Debt Crisis: Measures that extent to which respondents are familiar with details about the European debt crisis. More specifically, respondents are presented with a list of European countries and asked to identify which the countries received financial bailout assistance. For variable construction, respondents were given +1 points for all correct selections and -1 points for all incorrect selections. 


\section{Appendix C: Additional Results and Robustness Checks}

Reported here are the additional results and checks we conducted that are referenced in the text.

- Linear probability models explaining opposition to the Grexit, pooled and by country: Tables C.1 and C.2.

- Comparing logit and probit model results to linear probability model resuls: Table C.9.

- Linear regressions testing full set of mechanisms by country: Tables C.3, C.4, C.5, and C.6.

- Linear probability models explaining opposition to the Grexit, pooled and by country, when using the 5-point ordinal version of the Grexit opposition variable: Tables C.7 and C.8.

- Linear probability models explaining opposition to the Grexit, and linear regressions testing full set of mechanisms, when ideology is measured using different bins on the 11-point scale: Tables C.11, C.12, and C.13

- Linear regressions testing full set of mechanisms by country, when using respondents' party identification and coding the parties based on the 2014 Chapel Hill Expert Survey left-right party placements: Tables C.14, C.15, C.16, and C.17.

- Linear probability models explaining opposition to the Grexit, pooled and by country, when including pairwise interactions of all covariates: Table C.10

- Results from formal causal mediation: Tables C.18 and C.19.

- Testing interactions between ideology and knowledge about the European debt crisis in explaining opposition to the Grexit: Table C.20. 
Table C.1: Linear Probability Model - DV: Probability of Being Opposed to Grexit (Full Sample)

\begin{tabular}{|c|c|c|c|}
\hline & Model 1 & Model 2 & Model 3 \\
\hline (Intercept) & $\begin{array}{l}0.532^{*} \\
(0.024)\end{array}$ & $\begin{array}{l}0.536^{*} \\
(0.024)\end{array}$ & $\begin{array}{l}0.353^{*} \\
(0.025)\end{array}$ \\
\hline Income Quintile 1 & $\begin{array}{c}-0.037^{*} \\
(0.013)\end{array}$ & $\begin{array}{c}-0.034^{*} \\
(0.013)\end{array}$ & $\begin{array}{l}-0.020 \\
(0.013)\end{array}$ \\
\hline Income Quintile 2 & $\begin{array}{l}-0.014 \\
(0.012)\end{array}$ & $\begin{array}{l}-0.010 \\
(0.012)\end{array}$ & $\begin{array}{l}-0.005 \\
(0.012)\end{array}$ \\
\hline Income Quintile 4 & $\begin{array}{c}0.002 \\
(0.015)\end{array}$ & $\begin{array}{c}0.003 \\
(0.014)\end{array}$ & $\begin{array}{c}0.001 \\
(0.014)\end{array}$ \\
\hline Income Quintile 5 & $\begin{array}{l}-0.015 \\
(0.018)\end{array}$ & $\begin{array}{l}-0.003 \\
(0.018)\end{array}$ & $\begin{array}{l}-0.020 \\
(0.017)\end{array}$ \\
\hline Employed & $\begin{array}{l}-0.014 \\
(0.011)\end{array}$ & $\begin{array}{l}-0.011 \\
(0.011)\end{array}$ & $\begin{array}{l}-0.009 \\
(0.010)\end{array}$ \\
\hline Public Income Source & $\begin{array}{l}-0.007 \\
(0.013)\end{array}$ & $\begin{array}{l}-0.011 \\
(0.013)\end{array}$ & $\begin{array}{l}-0.001 \\
(0.012)\end{array}$ \\
\hline Public Sector Experience & $\begin{array}{c}0.009 \\
(0.011)\end{array}$ & $\begin{array}{c}0.001 \\
(0.011)\end{array}$ & $\begin{array}{c}0.003 \\
(0.010)\end{array}$ \\
\hline Investments & $\begin{array}{l}-0.016 \\
(0.011)\end{array}$ & $\begin{array}{c}0.003 \\
(0.011)\end{array}$ & $\begin{array}{l}-0.009 \\
(0.011)\end{array}$ \\
\hline Own Home & $\begin{array}{c}0.013 \\
(0.010)\end{array}$ & $\begin{array}{c}0.019 \\
(0.010)\end{array}$ & $\begin{array}{c}0.008 \\
(0.010)\end{array}$ \\
\hline Mortgage & $\begin{array}{c}-0.024^{*} \\
(0.011)\end{array}$ & $\begin{array}{l}-0.017 \\
(0.011)\end{array}$ & $\begin{array}{l}-0.014 \\
(0.010)\end{array}$ \\
\hline HS Degree & $\begin{array}{l}0.037^{*} \\
(0.014)\end{array}$ & $\begin{array}{l}0.034^{*} \\
(0.013)\end{array}$ & $\begin{array}{c}0.022 \\
(0.013)\end{array}$ \\
\hline Bachelor's Degree & $\begin{array}{l}0.076^{*} \\
(0.017)\end{array}$ & $\begin{array}{l}0.065^{*} \\
(0.017)\end{array}$ & $\begin{array}{c}0.029 \\
(0.016)\end{array}$ \\
\hline Graduate Degree & $\begin{array}{l}0.133^{*} \\
(0.016)\end{array}$ & $\begin{array}{l}0.120^{*} \\
(0.016)\end{array}$ & $\begin{array}{l}0.074^{*} \\
(0.016)\end{array}$ \\
\hline Female & $\begin{array}{l}0.043^{*} \\
(0.009)\end{array}$ & $\begin{array}{l}0.036^{*} \\
(0.009)\end{array}$ & $\begin{array}{l}0.031^{*} \\
(0.009)\end{array}$ \\
\hline Age $30-44$ & $\begin{array}{c}-0.028^{*} \\
(0.013)\end{array}$ & $\begin{array}{l}-0.021 \\
(0.013)\end{array}$ & $\begin{array}{l}-0.006 \\
(0.012)\end{array}$ \\
\hline Age $45-64$ & $\begin{array}{c}0.016 \\
(0.013)\end{array}$ & $\begin{array}{c}0.017 \\
(0.013)\end{array}$ & $\begin{array}{c}0.020 \\
(0.013)\end{array}$ \\
\hline Age $65+$ & $\begin{array}{c}0.019 \\
(0.022)\end{array}$ & $\begin{array}{c}0.040 \\
(0.022)\end{array}$ & $\begin{array}{c}0.038 \\
(0.021)\end{array}$ \\
\hline \# Children & $\begin{array}{c}-0.017^{*} \\
(0.004)\end{array}$ & $\begin{array}{c}-0.015^{*} \\
(0.004)\end{array}$ & $\begin{array}{c}-0.009^{*} \\
(0.004)\end{array}$ \\
\hline Voted & $\begin{array}{l}-0.017 \\
(0.014)\end{array}$ & $\begin{array}{l}-0.014 \\
(0.014)\end{array}$ & $\begin{array}{l}-0.012 \\
(0.013)\end{array}$ \\
\hline Far Left & & $\begin{array}{l}0.128^{*} \\
(0.012)\end{array}$ & $\begin{array}{l}0.111^{*} \\
(0.012)\end{array}$ \\
\hline Left & & $\begin{array}{l}0.105^{*} \\
(0.013)\end{array}$ & $\begin{array}{l}0.073^{*} \\
(0.012)\end{array}$ \\
\hline Right & & $\begin{array}{c}-0.070^{*} \\
(0.013)\end{array}$ & $\begin{array}{c}-0.078^{*} \\
(0.013)\end{array}$ \\
\hline Far Right & & $\begin{array}{c}-0.178^{*} \\
(0.014)\end{array}$ & $\begin{array}{c}-0.142^{*} \\
(0.014)\end{array}$ \\
\hline Pro-EU & & & $\begin{array}{l}0.269^{*} \\
(0.009)\end{array}$ \\
\hline High Empathy & & & $\begin{array}{l}0.029^{*} \\
(0.009)\end{array}$ \\
\hline Pro-Redistribution & & & $\begin{array}{l}0.028^{*} \\
(0.009)\end{array}$ \\
\hline High Knowledge & & & $\begin{array}{l}0.040^{*} \\
(0.009)\end{array}$ \\
\hline High Interest & & & $\begin{array}{c}-0.049^{*} \\
(0.009)\end{array}$ \\
\hline $\mathrm{R}^{2}$ & 0.042 & 0.083 & 0.149 \\
\hline Adj. $R^{2}$ & 0.041 & 0.081 & 0.147 \\
\hline Num. obs. & 12839 & 12839 & 12839 \\
\hline
\end{tabular}


Table C.2: Linear Probability Model - DV: Probability of Being Opposed to Grexit (by Country)

\begin{tabular}{|c|c|c|c|c|c|c|c|c|c|c|c|c|}
\hline & $\begin{array}{l}\text { Model 1 } \\
\text { France }\end{array}$ & $\begin{array}{l}\text { Model 2 } \\
\text { France }\end{array}$ & $\begin{array}{l}\text { Model } 3 \\
\text { France } \\
\end{array}$ & $\begin{array}{l}\text { Model } 4 \\
\text { Italy }\end{array}$ & $\begin{array}{l}\text { Model } 5 \\
\text { Italy }\end{array}$ & $\begin{array}{l}\text { Model } 6 \\
\text { Italy }\end{array}$ & $\begin{array}{l}\text { Model } 7 \\
\text { Spain }\end{array}$ & $\begin{array}{l}\text { Model } 8 \\
\text { Spain }\end{array}$ & $\begin{array}{l}\text { Model 9 } \\
\text { Spain }\end{array}$ & $\begin{array}{c}\text { Model } 10 \\
\text { UK }\end{array}$ & $\begin{array}{l}\text { Model } 11 \\
\text { UK }\end{array}$ & $\begin{array}{l}\text { Model } 12 \\
\text { UK }\end{array}$ \\
\hline (Intercept) & $0.520^{*}$ & $0.505^{*}$ & $0.312^{*}$ & $0.442^{*}$ & $0.466^{*}$ & $0.259^{*}$ & $0.653^{*}$ & $0.615^{*}$ & $0.416^{*}$ & $0.438^{*}$ & $0.388^{*}$ & $0.232^{*}$ \\
\hline & $(0.043)$ & $(0.044)$ & $(0.044)$ & $(0.048)$ & $(0.048)$ & $(0.049)$ & $(0.043)$ & $(0.045)$ & $(0.049)$ & $(0.056)$ & $(0.057)$ & $(0.059)$ \\
\hline Income Quintile 1 & -0.013 & -0.015 & -0.011 & -0.041 & -0.038 & -0.019 & $-0.083^{*}$ & $-0.078^{*}$ & $-0.052^{*}$ & -0.011 & -0.009 & 0.001 \\
\hline & $(0.023)$ & $(0.023)$ & $(0.022)$ & $(0.025)$ & $(0.024)$ & $(0.023)$ & $(0.027)$ & $(0.027)$ & $(0.026)$ & $(0.035)$ & $(0.034)$ & $(0.033)$ \\
\hline Income Quintile 2 & $\begin{array}{l}0.020 \\
(0.024)\end{array}$ & $\begin{array}{l}0.024 \\
(0.024)\end{array}$ & $\begin{array}{l}0.026 \\
(0.023)\end{array}$ & $\begin{array}{l}-0.030 \\
(0.024)\end{array}$ & $\begin{array}{l}-0.031 \\
(0.023)\end{array}$ & $\begin{array}{l}-0.021 \\
(0.022)\end{array}$ & $\begin{array}{l}-0.023 \\
(0.021)\end{array}$ & $\begin{array}{l}-0.018 \\
(0.021)\end{array}$ & $\begin{array}{l}-0.009 \\
(0.021)\end{array}$ & $\begin{array}{l}-0.040 \\
(0.032)\end{array}$ & $\begin{array}{l}-0.031 \\
(0.032)\end{array}$ & $\begin{array}{l}-0.025 \\
(0.031)\end{array}$ \\
\hline Income Quintile 4 & $\begin{array}{l}0.008 \\
(0.026)\end{array}$ & $\begin{array}{l}0.018 \\
(0.025)\end{array}$ & $\begin{array}{l}0.002 \\
(0.024)\end{array}$ & $\begin{array}{l}-0.005 \\
(0.028)\end{array}$ & $\begin{array}{l}-0.010 \\
(0.028)\end{array}$ & $\begin{array}{l}-0.003 \\
(0.026)\end{array}$ & $\begin{array}{l}-0.007 \\
(0.029)\end{array}$ & $\begin{array}{l}-0.002 \\
(0.029)\end{array}$ & $\begin{array}{l}0.002 \\
(0.029)\end{array}$ & $\begin{array}{l}-0.002 \\
(0.035)\end{array}$ & $\begin{array}{l}-0.009 \\
(0.035)\end{array}$ & $\begin{array}{l}-0.009 \\
(0.033)\end{array}$ \\
\hline Income Quintile 5 & 0.007 & 0.025 & -0.018 & -0.029 & -0.028 & -0.043 & -0.054 & -0.037 & -0.028 & -0.021 & -0.019 & -0.024 \\
\hline Employed & -0.015 & -0.010 & 0.002 & 0.006 & -0.000 & 0.001 & -0.020 & -0.015 & -0.023 & -0.047 & -0.032 & $\begin{array}{l}(0.038) \\
-0.028\end{array}$ \\
\hline & $(0.021)$ & $(0.020)$ & $(0.020)$ & $(0.021)$ & $(0.020)$ & $(0.019)$ & $(0.021)$ & $(0.021)$ & $(0.020)$ & $(0.029)$ & $(0.029)$ & $(0.027)$ \\
\hline Public Income Source & $\begin{array}{l}0.003 \\
(0.025)\end{array}$ & $\begin{array}{l}-0.006 \\
(0.024)\end{array}$ & $\begin{array}{l}0.006 \\
(0.024)\end{array}$ & $\begin{array}{l}0.014 \\
(0.024)\end{array}$ & $\begin{array}{l}-0.002 \\
(0.023)\end{array}$ & $\begin{array}{l}0.009 \\
(0.022)\end{array}$ & $\begin{array}{l}-0.013 \\
(0.026)\end{array}$ & $\begin{array}{l}-0.013 \\
(0.026)\end{array}$ & $\begin{array}{l}-0.013 \\
(0.025)\end{array}$ & $\begin{array}{l}-0.060 \\
(0.032)\end{array}$ & $\begin{array}{l}-0.041 \\
(0.031)\end{array}$ & -0.027 \\
\hline Public Sector Experience & 0.005 & -0.010 & -0.003 & 0.001 & -0.002 & -0.008 & -0.007 & -0.011 & -0.004 & $0.058^{*}$ & 0.045 & 0.045 \\
\hline & $(0.021)$ & $(0.020)$ & $(0.019)$ & $(0.023)$ & $(0.022)$ & $(0.021)$ & $(0.021)$ & $(0.020)$ & $(0.020)$ & $(0.025)$ & $(0.025)$ & $(0.024)$ \\
\hline Investments & $\begin{array}{l}0.007 \\
(0.022)\end{array}$ & $\begin{array}{l}0.027 \\
(0.021)\end{array}$ & $\begin{array}{l}0.014 \\
(0.021)\end{array}$ & $\begin{array}{l}-0.020 \\
(0.020)\end{array}$ & $\begin{array}{l}-0.008 \\
(0.019)\end{array}$ & $\begin{array}{l}-0.024 \\
(0.019)\end{array}$ & $\begin{array}{l}-0.029 \\
(0.022)\end{array}$ & $\begin{array}{l}-0.015 \\
(0.021)\end{array}$ & $\begin{array}{l}-0.014 \\
(0.021)\end{array}$ & $\begin{array}{l}-0.039 \\
(0.027)\end{array}$ & $\begin{array}{l}-0.000 \\
(0.026)\end{array}$ & $\begin{array}{l}-0.020 \\
(0.026)\end{array}$ \\
\hline Own Home & $\begin{array}{l}0.007 \\
(0.018)\end{array}$ & $\begin{array}{l}0.010 \\
(0.017)\end{array}$ & $\begin{array}{l}0.004 \\
(0.017)\end{array}$ & $\begin{array}{l}0.043^{*} \\
(0.020)\end{array}$ & $\begin{array}{l}0.051^{*} \\
(0.020)\end{array}$ & $\begin{array}{l}0.034 \\
(0.019)\end{array}$ & $\begin{array}{l}-0.011 \\
(0.020)\end{array}$ & $\begin{array}{l}-0.007 \\
(0.020)\end{array}$ & $\begin{array}{l}-0.017 \\
(0.020)\end{array}$ & $\begin{array}{l}0.035 \\
(0.028)\end{array}$ & $\begin{array}{l}0.047 \\
(0.027)\end{array}$ & $\begin{array}{l}0.033 \\
(0.027)\end{array}$ \\
\hline Mortgage & $\begin{array}{l}-0.000 \\
(0.027)\end{array}$ & $\begin{array}{l}0.008 \\
(0.027)\end{array}$ & $\begin{array}{l}0.024 \\
(0.026)\end{array}$ & $\begin{array}{l}-0.016 \\
(0.019)\end{array}$ & $\begin{array}{l}-0.011 \\
(0.019)\end{array}$ & $\begin{array}{l}-0.010 \\
(0.018)\end{array}$ & $\begin{array}{c}-0.039^{*} \\
(0.019)\end{array}$ & $\begin{array}{l}-0.035 \\
(0.018)\end{array}$ & $\begin{array}{l}-0.030 \\
(0.018)\end{array}$ & $\begin{array}{l}-0.048 \\
(0.029)\end{array}$ & $\begin{array}{l}-0.038 \\
(0.028)\end{array}$ & $\begin{array}{l}-0.036 \\
(0.027)\end{array}$ \\
\hline HS Degree & $\begin{array}{l}0.041 \\
(0.029)\end{array}$ & $\begin{array}{c}0.044 \\
(0.029)\end{array}$ & $\begin{array}{l}0.026 \\
(0.028)\end{array}$ & $\begin{array}{l}0.033 \\
(0.027)\end{array}$ & $\begin{array}{l}0.034 \\
(0.027)\end{array}$ & $\begin{array}{l}0.021 \\
(0.026)\end{array}$ & $\begin{array}{l}0.028 \\
(0.026)\end{array}$ & $\begin{array}{l}0.016 \\
(0.026)\end{array}$ & $\begin{array}{c}0.010) \\
0.006 \\
(0.025)\end{array}$ & $0.065^{*}$ & $0.066^{*}$ & $\begin{array}{l}0.062^{*} \\
0.026)\end{array}$ \\
\hline Bachelor's Degree & $0.119^{*}$ & $0.117^{*}$ & 0.065 & 0.053 & 0.046 & 0.025 & 0.048 & 0.034 & 0.004 & $0.117^{*}$ & $0.092^{*}$ & $0.066^{*}$ \\
\hline Graduate Degree & $\begin{array}{l}(0.039) \\
0.192^{*}\end{array}$ & $\begin{array}{l}(0.038) \\
0.174^{*}\end{array}$ & $\begin{array}{l}(0.037) \\
0.099^{*}\end{array}$ & $\begin{array}{l}(0.036) \\
0.123^{*}\end{array}$ & $\begin{array}{l}(0.036) \\
0.112^{*}\end{array}$ & $\begin{array}{l}(0.035) \\
0.073^{*}\end{array}$ & $\begin{array}{l}(0.029) \\
0.083^{*}\end{array}$ & $\begin{array}{l}(0.029) \\
0.074^{*}\end{array}$ & $\begin{array}{c}(0.029) \\
0.040\end{array}$ & $\begin{array}{l}(0.035) \\
0.140^{*}\end{array}$ & $\begin{array}{l}(0.034) \\
0.119^{*}\end{array}$ & $\begin{array}{c}(0.033) \\
0.088\end{array}$ \\
\hline & $(0.035)$ & $(0.034)$ & $(0.033)$ & $(0.031)$ & $(0.030)$ & $(0.030)$ & $(0.027)$ & $(0.027)$ & $(0.028)$ & $(0.048)$ & $(0.047)$ & $(0.045)$ \\
\hline Female & $0.039^{*}$ & 0.028 & $0.031^{*}$ & $0.066^{*}$ & $0.054^{*}$ & $0.038^{*}$ & 0.026 & 0.025 & 0.029 & 0.041 & 0.039 & 0.023 \\
\hline Age $30-44$ & -0.001 & -0.003 & 0.020 & -0.029 & -0.013 & $\begin{array}{l}(0.010) \\
-0.003\end{array}$ & -0.036 & -0.032 & -0.023 & -0.023 & -0.011 & $\begin{array}{l}(0.022) \\
0.007\end{array}$ \\
\hline & $(0.022)$ & $(0.022)$ & $(0.021)$ & $(0.025)$ & $(0.025)$ & $(0.024)$ & $(0.024)$ & $(0.024)$ & $(0.024)$ & $(0.040)$ & $(0.040)$ & $(0.039)$ \\
\hline Age $45-64$ & $\begin{array}{l}0.012 \\
(0.024)\end{array}$ & $\begin{array}{l}0.008 \\
(0.023)\end{array}$ & $\begin{array}{l}0.029 \\
(0.023)\end{array}$ & $\begin{array}{l}0.098^{*} \\
(0.026)\end{array}$ & $\begin{array}{l}0.103^{*} \\
(0.026)\end{array}$ & $\begin{array}{l}0.085^{*} \\
(0.025)\end{array}$ & $\begin{array}{l}-0.012 \\
(0.026)\end{array}$ & $\begin{array}{l}-0.010 \\
(0.025)\end{array}$ & $\begin{array}{l}-0.014 \\
(0.026)\end{array}$ & $\begin{array}{l}-0.060 \\
(0.039)\end{array}$ & $\begin{array}{l}-0.066 \\
(0.038)\end{array}$ & $\begin{array}{l}-0.030 \\
(0.038)\end{array}$ \\
\hline Age $65+$ & $\begin{array}{l}0.034 \\
(0.037)\end{array}$ & $\begin{array}{l}0.064 \\
(0.036)\end{array}$ & $\begin{array}{l}0.066 \\
(0.035)\end{array}$ & $\begin{array}{l}0.158^{*} \\
(0.048)\end{array}$ & $\begin{array}{l}0.173^{*} \\
(0.047)\end{array}$ & $\begin{array}{l}0.154^{*} \\
(0.042)\end{array}$ & $\begin{array}{l}0.056 \\
(0.090)\end{array}$ & $\begin{array}{l}0.055 \\
(0.086)\end{array}$ & $\begin{array}{l}0.048 \\
(0.085)\end{array}$ & $\begin{array}{l}-0.077 \\
(0.050)\end{array}$ & $\begin{array}{l}-0.074 \\
(0.049)\end{array}$ & $\begin{array}{l}-0.046 \\
(0.048)\end{array}$ \\
\hline \# Children & $\begin{array}{l}-0.021^{*} \\
(0.006)\end{array}$ & $\begin{array}{l}-0.021^{*} \\
(0.006)\end{array}$ & $\begin{array}{l}-0.013^{*} \\
(0.006)\end{array}$ & $\begin{array}{l}-0.031^{*} \\
(0.009)\end{array}$ & $\begin{array}{c}-0.030^{*} \\
(0.009)\end{array}$ & $\begin{array}{l}-0.023^{*} \\
(0.008)\end{array}$ & -0.007 & $\begin{array}{l}-0.003 \\
(0.008)\end{array}$ & $\begin{array}{l}0.002 \\
0.008\end{array}$ & -0.001 & $\begin{array}{l}0.000 \\
(0.008)\end{array}$ & $\begin{array}{l}0.005 \\
(0.088)\end{array}$ \\
\hline Voted & $\begin{array}{l}-0.046 \\
(0.026)\end{array}$ & $\begin{array}{l}-0.043 \\
(0.025)\end{array}$ & $\begin{array}{l}-0.037 \\
(0.025)\end{array}$ & $\begin{array}{l}0.032 \\
(0.030)\end{array}$ & $\begin{array}{l}0.019 \\
(0.030)\end{array}$ & $\begin{array}{l}0.001 \\
(0.029)\end{array}$ & $\begin{array}{l}0.031 \\
(0.026)\end{array}$ & $\begin{array}{l}0.037 \\
(0.026)\end{array}$ & $\begin{array}{c}0.030 \\
(0.026)\end{array}$ & $\begin{array}{c}-0.069^{*} \\
(0.032)\end{array}$ & $\begin{array}{l}-0.049 \\
(0.032)\end{array}$ & $\begin{array}{l}-0.028 \\
(0.031)\end{array}$ \\
\hline Far Left & & $\begin{array}{l}(0.025) \\
0.183^{*}\end{array}$ & $\begin{array}{l}(0.025) \\
0.139^{*}\end{array}$ & & $\begin{array}{l}(0.030) \\
0.105^{*}\end{array}$ & $\begin{array}{l}(0.029) \\
0.063^{*}\end{array}$ & & $\begin{array}{l}(0.026) \\
0.075^{*}\end{array}$ & $\begin{array}{l}(0.026) \\
0.092^{*}\end{array}$ & & $\begin{array}{l}\left(0.193^{*}\right) \\
0.193^{*}\end{array}$ & $\begin{array}{l}(0.031) \\
0.162^{*}\end{array}$ \\
\hline & & $(0.024)$ & $(0.023)$ & & $(0.024)$ & $(0.023)$ & & $(0.022)$ & $(0.023)$ & & $(0.037)$ & $(0.038)$ \\
\hline Left & & $0.127^{*}$ & $0.091^{*}$ & & $0.083^{*}$ & 0.032 & & $0.088^{*}$ & $0.080^{*}$ & & $0.119^{*}$ & $0.088^{*}$ \\
\hline Right & & $\begin{array}{l}(0.024) \\
-0.021\end{array}$ & $\begin{array}{l}(0.023) \\
-0.041\end{array}$ & & $\begin{array}{l}(0.024) \\
-0.105^{*}\end{array}$ & $\begin{array}{l}(0.023) \\
-0.104^{*}\end{array}$ & & $\begin{array}{l}(0.023) \\
-0.099^{*}\end{array}$ & $\begin{array}{l}(0.023) \\
-0.105^{*}\end{array}$ & & $\begin{array}{l}(0.032) \\
-0.071^{*}\end{array}$ & $\begin{array}{l}(0.032) \\
-0.060^{*}\end{array}$ \\
\hline & & $(0.023)$ & $(0.023)$ & & $(0.026)$ & $(0.024)$ & & $(0.028)$ & $(0.028)$ & & $(0.029)$ & $(0.028)$ \\
\hline Far Right & & $\begin{array}{l}-0.166^{*} \\
(0.023)\end{array}$ & $\begin{array}{l}-0.138^{*} \\
(0.023)\end{array}$ & & $\begin{array}{l}-0.209^{*} \\
(0.026)\end{array}$ & $\begin{array}{l}-0.149^{*} \\
(0.026\end{array}$ & & $\begin{array}{l}-0.119^{*} \\
(0.039)\end{array}$ & $\begin{array}{l}-0.117^{*} \\
(0.038\end{array}$ & & $\begin{array}{c}-0.175^{*} \\
(0.031)\end{array}$ & $\begin{array}{c}-0.129^{*} \\
(0.033)\end{array}$ \\
\hline Pro-EU & & & $0.288^{*}$ & & & $0.301^{*}$ & & & $0.219^{*}$ & & & $0.238^{*}$ \\
\hline & & & $(0.016)$ & & & $(0.018)$ & & & $(0.019)$ & & & $(0.022)$ \\
\hline High Empathy & & & $0.034^{*}$ & & & 0.013 & & & 0.020 & & & $0.046^{*}$ \\
\hline Pro-Redistribution & & & $(0.015)$ & & & $(0.017)$ & & & $(0.017)$ & & & $(0.022)$ \\
\hline & & & $\begin{array}{l}0.010 \\
(0.016)\end{array}$ & & & $\begin{array}{l}0.030 \\
(0.017)\end{array}$ & & & $(0.019)$ & & & $(0.022)$ \\
\hline High Knowledge & & & $0.032^{*}$ & & & $0.093^{*}$ & & & 0.012 & & & 0.013 \\
\hline & & & $(0.016)$ & & & $(0.017)$ & & & $(0.020)$ & & & $(0.022)$ \\
\hline High Interest & & & $\begin{array}{l}-0.012 \\
(0.018)\end{array}$ & & & $\begin{array}{l}-0.065^{*} \\
(0.017)\end{array}$ & & & $\begin{array}{l}-0.031 \\
(0.018)\end{array}$ & & & $\begin{array}{c}-0.102^{*} \\
(0.023)\end{array}$ \\
\hline $\mathrm{R}^{2}$ & 0.021 & 0.074 & 0.151 & 0.028 & 0.076 & 0.164 & 0.013 & 0.035 & 0.077 & 0.027 & 0.075 & 0.137 \\
\hline Adj. $R^{2}$ & 0.017 & 0.06 & 0. & 0.022 & 0.070 & 0.15 & 0.007 & 0.029 & 0.069 & 0.018 & 0.064 & 0.125 \\
\hline Num. obs. & 3886 & 3886 & 3886 & 3473 & 3473 & 3473 & 3471 & 3471 & 3471 & 2009 & 2009 & 2009 \\
\hline
\end{tabular}


Table C.3: Mechanism Regressions (France)

\begin{tabular}{|c|c|c|c|c|c|c|}
\hline & $\begin{array}{l}\text { Model } 1 \\
\text { Oppose } \\
\text { Grexit } \\
\text { (Binary) }\end{array}$ & $\begin{array}{l}\text { Model } 2 \\
\text { Oppose } \\
\text { Grexit } \\
\text { (Binary) }\end{array}$ & $\begin{array}{c}\text { Model } 3 \\
\text { Pro- } \\
\text { Redistribution } \\
\text { (Binary) }\end{array}$ & $\begin{array}{l}\text { Model } 4 \\
\text { High } \\
\text { Empathy } \\
\text { (Binary) }\end{array}$ & $\begin{array}{l}\text { Model } 5 \\
\text { EU } \\
\text { Support } \\
\text { (3-Point) }\end{array}$ & $\begin{array}{c}\text { Model } 6 \\
\text { Positive Expected } \\
\text { Grexit Impact } \\
\text { (3-Point) }\end{array}$ \\
\hline Far Left & $\begin{array}{l}0.183^{*} \\
(0.024)\end{array}$ & $\begin{array}{l}0.083^{*} \\
(0.022)\end{array}$ & $\begin{array}{l}0.226^{*} \\
(0.022)\end{array}$ & $\begin{array}{l}0.204^{*} \\
(0.024)\end{array}$ & $\begin{array}{l}0.248^{*} \\
(0.039)\end{array}$ & $\begin{array}{c}-0.245^{*} \\
(0.036)\end{array}$ \\
\hline Left & $\begin{array}{l}0.127^{*} \\
(0.024)\end{array}$ & $\begin{array}{l}0.075^{*} \\
(0.021)\end{array}$ & $\begin{array}{l}0.120^{*} \\
(0.024)\end{array}$ & $\begin{array}{l}0.057^{*} \\
(0.025)\end{array}$ & $\begin{array}{l}0.221^{*} \\
(0.038)\end{array}$ & $\begin{array}{c}-0.078^{*} \\
(0.037)\end{array}$ \\
\hline Right & $\begin{array}{l}-0.021 \\
(0.023)\end{array}$ & $\begin{array}{l}-0.034 \\
(0.021)\end{array}$ & $\begin{array}{c}-0.132^{*} \\
(0.023)\end{array}$ & $\begin{array}{c}0.009 \\
(0.023)\end{array}$ & $\begin{array}{l}0.158^{*} \\
(0.037)\end{array}$ & $\begin{array}{c}0.031 \\
(0.035)\end{array}$ \\
\hline Far Right & $\begin{array}{c}-0.166^{*} \\
(0.023)\end{array}$ & $\begin{array}{c}-0.115^{*} \\
(0.021)\end{array}$ & $\begin{array}{c}-0.116^{*} \\
(0.023)\end{array}$ & $\begin{array}{l}0.025 \\
(0.023)\end{array}$ & $\begin{array}{c}-0.129^{*} \\
(0.037)\end{array}$ & $\begin{array}{l}0.137^{*} \\
(0.035)\end{array}$ \\
\hline Pro-Redistribution & & $\begin{array}{c}0.012 \\
(0.015)\end{array}$ & & & & \\
\hline High Empathy & & $\begin{array}{l}0.027 \\
(0.014)\end{array}$ & & & & \\
\hline EU Support & & $\begin{array}{l}0.135^{*} \\
(0.009)\end{array}$ & & & & \\
\hline Positive Expected Grexit Impact & & $\begin{array}{c}-0.240^{*} \\
(0.009)\end{array}$ & & & & \\
\hline $\begin{array}{l}\text { Economic, Demographic, } \\
\text { Additional Controls }\end{array}$ & $\checkmark$ & $\checkmark$ & $\checkmark$ & $\checkmark$ & $\checkmark$ & $\checkmark$ \\
\hline $\mathrm{R}^{2}$ & 0.074 & 0.269 & 0.098 & 0.048 & 0.110 & 0.049 \\
\hline Adj. $R^{2}$ & 0.068 & 0.264 & 0.093 & 0.042 & 0.105 & 0.044 \\
\hline Num. obs. & 3886 & 3886 & 3886 & 3886 & 3886 & 3886 \\
\hline
\end{tabular}


Table C.4: Mechanism Regressions (Italy)

\begin{tabular}{|c|c|c|c|c|c|c|}
\hline & $\begin{array}{l}\text { Model } 1 \\
\text { Oppose } \\
\text { Grexit } \\
\text { (Binary) }\end{array}$ & $\begin{array}{l}\text { Model } 2 \\
\text { Oppose } \\
\text { Grexit } \\
\text { (Binary) }\end{array}$ & $\begin{array}{c}\text { Model } 3 \\
\text { Pro- } \\
\text { Redistribution } \\
\text { (Binary) }\end{array}$ & $\begin{array}{l}\text { Model } 4 \\
\text { High } \\
\text { Empathy } \\
\text { (Binary) }\end{array}$ & $\begin{array}{l}\text { Model } 5 \\
\text { EU } \\
\text { Support } \\
\text { (3-Point) }\end{array}$ & $\begin{array}{c}\text { Model } 6 \\
\text { Positive Expected } \\
\text { Grexit Impact } \\
\text { (3-Point) }\end{array}$ \\
\hline Far Left & $\begin{array}{l}0.105^{*} \\
(0.024)\end{array}$ & $\begin{array}{c}0.019 \\
(0.021)\end{array}$ & $\begin{array}{l}0.171^{*} \\
(0.022)\end{array}$ & $\begin{array}{l}0.108^{*} \\
(0.024)\end{array}$ & $\begin{array}{l}0.285^{*} \\
(0.038)\end{array}$ & $\begin{array}{c}-0.159^{*} \\
(0.036)\end{array}$ \\
\hline Left & $\begin{array}{l}0.083^{*} \\
(0.024)\end{array}$ & $\begin{array}{l}0.005 \\
(0.021)\end{array}$ & $\begin{array}{l}0.054^{*} \\
(0.024)\end{array}$ & $\begin{array}{l}0.027 \\
(0.025)\end{array}$ & $\begin{array}{l}0.301^{*} \\
(0.037)\end{array}$ & $\begin{array}{c}-0.127^{*} \\
(0.037)\end{array}$ \\
\hline Right & $\begin{array}{c}-0.105^{*} \\
(0.026)\end{array}$ & $\begin{array}{c}-0.085^{*} \\
(0.023)\end{array}$ & $\begin{array}{l}-0.135^{*} \\
(0.025)\end{array}$ & $\begin{array}{c}-0.071^{*} \\
(0.025)\end{array}$ & $\begin{array}{c}0.063 \\
(0.039)\end{array}$ & $\begin{array}{l}0.108^{*} \\
(0.038)\end{array}$ \\
\hline Far Right & $\begin{array}{c}-0.209^{*} \\
(0.026)\end{array}$ & $\begin{array}{c}-0.106^{*} \\
(0.023)\end{array}$ & $\begin{array}{c}-0.162^{*} \\
(0.026)\end{array}$ & $\begin{array}{l}-0.006 \\
(0.026)\end{array}$ & $\begin{array}{c}-0.225^{*} \\
(0.043)\end{array}$ & $\begin{array}{l}0.258^{*} \\
(0.042)\end{array}$ \\
\hline Pro-Redistribution & & $\begin{array}{c}0.006 \\
(0.016)\end{array}$ & & & & \\
\hline High Empathy & & $\begin{array}{l}-0.002 \\
(0.015)\end{array}$ & & & & \\
\hline EU Support & & $\begin{array}{l}0.150^{*} \\
(0.010)\end{array}$ & & & & \\
\hline Positive Expected Grexit Impact & & $\begin{array}{c}-0.263^{*} \\
(0.009)\end{array}$ & & & & \\
\hline $\begin{array}{l}\text { Economic, Demographic, } \\
\text { Additional Controls }\end{array}$ & $\checkmark$ & $\checkmark$ & $\checkmark$ & $\checkmark$ & $\checkmark$ & $\checkmark$ \\
\hline $\mathrm{R}^{2}$ & 0.076 & 0.300 & 0.074 & 0.070 & 0.095 & 0.066 \\
\hline Adj. $R^{2}$ & 0.070 & 0.294 & 0.068 & 0.064 & 0.089 & 0.060 \\
\hline Num. obs. & 3473 & 3473 & 3473 & 3473 & 3473 & 3473 \\
\hline
\end{tabular}


Table C.5: Mechanism Regressions (Spain)

\begin{tabular}{|c|c|c|c|c|c|c|}
\hline & $\begin{array}{l}\text { Model } 1 \\
\text { Oppose } \\
\text { Grexit } \\
\text { (Binary) }\end{array}$ & $\begin{array}{l}\text { Model } 2 \\
\text { Oppose } \\
\text { Grexit } \\
\text { (Binary) }\end{array}$ & $\begin{array}{c}\text { Model } 3 \\
\text { Pro- } \\
\text { Redistribution } \\
\text { (Binary) }\end{array}$ & $\begin{array}{l}\text { Model } 4 \\
\text { High } \\
\text { Empathy } \\
\text { (Binary) }\end{array}$ & $\begin{array}{l}\text { Model } 5 \\
\text { EU } \\
\text { Support } \\
\text { (3-Point) }\end{array}$ & $\begin{array}{c}\text { Model } 6 \\
\text { Positive Expected } \\
\text { Grexit Impact } \\
\text { (3-Point) }\end{array}$ \\
\hline Far Left & $\begin{array}{l}0.075^{*} \\
(0.022)\end{array}$ & $\begin{array}{l}0.045^{*} \\
(0.020)\end{array}$ & $\begin{array}{l}0.235^{*} \\
(0.019)\end{array}$ & $\begin{array}{l}0.165^{*} \\
(0.022)\end{array}$ & $\begin{array}{c}-0.236^{*} \\
(0.036)\end{array}$ & $\begin{array}{c}-0.181^{*} \\
(0.032)\end{array}$ \\
\hline Left & $\begin{array}{l}0.088^{*} \\
(0.023)\end{array}$ & $\begin{array}{l}0.050^{*} \\
(0.021)\end{array}$ & $\begin{array}{l}0.159^{*} \\
(0.021)\end{array}$ & $\begin{array}{l}0.080^{*} \\
(0.023)\end{array}$ & $\begin{array}{l}-0.007 \\
(0.035)\end{array}$ & $\begin{array}{c}-0.127^{*} \\
(0.034)\end{array}$ \\
\hline Right & $\begin{array}{c}-0.099^{*} \\
(0.028)\end{array}$ & $\begin{array}{c}-0.088^{*} \\
(0.025)\end{array}$ & $\begin{array}{l}-0.113^{*} \\
(0.027)\end{array}$ & $\begin{array}{l}-0.029 \\
(0.028)\end{array}$ & $\begin{array}{l}0.140^{*} \\
(0.039)\end{array}$ & $\begin{array}{c}0.079 \\
(0.042)\end{array}$ \\
\hline Far Right & $\begin{array}{c}-0.119^{*} \\
(0.039)\end{array}$ & $\begin{array}{c}-0.062^{*} \\
(0.031)\end{array}$ & $\begin{array}{c}-0.135^{*} \\
(0.038)\end{array}$ & $\begin{array}{l}-0.008 \\
(0.039)\end{array}$ & $\begin{array}{l}0.121^{*} \\
(0.058)\end{array}$ & $\begin{array}{l}0.236^{*} \\
(0.066)\end{array}$ \\
\hline Pro-Redistribution & & $\begin{array}{c}0.028 \\
(0.017)\end{array}$ & & & & \\
\hline High Empathy & & $\begin{array}{l}-0.009 \\
(0.015)\end{array}$ & & & & \\
\hline EU Support & & $\begin{array}{l}0.107^{*} \\
(0.010)\end{array}$ & & & & \\
\hline Positive Expected Grexit Impact & & $\begin{array}{c}-0.281^{*} \\
(0.010)\end{array}$ & & & & \\
\hline $\begin{array}{l}\text { Economic, Demographic, } \\
\text { Additional Controls }\end{array}$ & $\checkmark$ & $\checkmark$ & $\checkmark$ & $\checkmark$ & $\checkmark$ & $\checkmark$ \\
\hline $\mathrm{R}^{2}$ & 0.035 & 0.256 & 0.113 & 0.063 & 0.097 & 0.054 \\
\hline Adj. $R^{2}$ & 0.029 & 0.250 & 0.107 & 0.056 & 0.091 & 0.048 \\
\hline Num. obs. & 3471 & 3471 & 3471 & 3471 & 3471 & 3471 \\
\hline
\end{tabular}


Table C.6: Mechanism Regressions (United Kingdom)

\begin{tabular}{|c|c|c|c|c|c|c|}
\hline & $\begin{array}{l}\text { Model } 1 \\
\text { Oppose } \\
\text { Grexit } \\
\text { (Binary) }\end{array}$ & $\begin{array}{l}\text { Model } 2 \\
\text { Oppose } \\
\text { Grexit } \\
\text { (Binary) }\end{array}$ & $\begin{array}{c}\text { Model } 3 \\
\text { Pro- } \\
\text { Redistribution } \\
\text { (Binary) }\end{array}$ & $\begin{array}{l}\text { Model } 4 \\
\text { High } \\
\text { Empathy } \\
\text { (Binary) }\end{array}$ & $\begin{array}{l}\text { Model } 5 \\
\text { EU } \\
\text { Support } \\
\text { (3-Point) }\end{array}$ & $\begin{array}{c}\text { Model } 6 \\
\text { Positive Expected } \\
\text { Grexit Impact } \\
\text { (3-Point) }\end{array}$ \\
\hline Far Left & $\begin{array}{l}0.193^{*} \\
(0.037)\end{array}$ & $\begin{array}{l}0.100^{*} \\
(0.034)\end{array}$ & $\begin{array}{l}0.300^{*} \\
(0.029)\end{array}$ & $\begin{array}{l}0.167^{*} \\
(0.034)\end{array}$ & $\begin{array}{l}0.447^{*} \\
(0.062)\end{array}$ & $\begin{array}{c}-0.153^{*} \\
(0.057)\end{array}$ \\
\hline Left & $\begin{array}{l}0.119^{*} \\
(0.032)\end{array}$ & $\begin{array}{l}0.059^{*} \\
(0.029)\end{array}$ & $\begin{array}{l}0.167^{*} \\
(0.030)\end{array}$ & $\begin{array}{l}0.091^{*} \\
(0.030)\end{array}$ & $\begin{array}{l}0.318^{*} \\
(0.053)\end{array}$ & $\begin{array}{l}-0.083 \\
(0.049)\end{array}$ \\
\hline Right & $\begin{array}{c}-0.071^{*} \\
(0.029)\end{array}$ & $\begin{array}{c}-0.065^{*} \\
(0.027)\end{array}$ & $\begin{array}{c}-0.121^{*} \\
(0.030)\end{array}$ & $\begin{array}{l}-0.030 \\
(0.030)\end{array}$ & $\begin{array}{l}0.038 \\
(0.051)\end{array}$ & $\begin{array}{l}0.044 \\
(0.046)\end{array}$ \\
\hline Far Right & $\begin{array}{c}-0.175^{*} \\
(0.031)\end{array}$ & $\begin{array}{c}-0.099^{*} \\
(0.029)\end{array}$ & $\begin{array}{c}-0.259^{*} \\
(0.033)\end{array}$ & $\begin{array}{c}0.018 \\
(0.035)\end{array}$ & $\begin{array}{l}-0.068 \\
(0.058)\end{array}$ & $\begin{array}{l}0.311^{*} \\
(0.055)\end{array}$ \\
\hline Pro-Redistribution & & $\begin{array}{l}-0.000 \\
(0.021)\end{array}$ & & & & \\
\hline High Empathy & & $\begin{array}{l}0.040^{*} \\
(0.020)\end{array}$ & & & & \\
\hline EU Support & & $\begin{array}{l}0.120^{*} \\
(0.012)\end{array}$ & & & & \\
\hline Positive Expected Grexit Impact & & $\begin{array}{c}-0.221^{*} \\
(0.012)\end{array}$ & & & & \\
\hline $\begin{array}{l}\text { Economic, Demographic, } \\
\text { Additional Controls }\end{array}$ & $\checkmark$ & $\checkmark$ & $\checkmark$ & $\checkmark$ & $\checkmark$ & $\checkmark$ \\
\hline $\mathrm{R}^{2}$ & 0.075 & 0.250 & 0.172 & 0.077 & 0.128 & 0.047 \\
\hline Adj. $R^{2}$ & 0.064 & 0.239 & 0.162 & 0.067 & 0.118 & 0.036 \\
\hline Num. obs. & 2009 & 2009 & 2009 & 2009 & 2009 & 2009 \\
\hline
\end{tabular}


Table C.7: Linear Regression - DV: Degree Opposed to Grexit (5-point Ordinal Version), Full Sample

\begin{tabular}{|c|c|c|c|}
\hline & Model 1 & Model 2 & Model 3 \\
\hline (Intercept) & -0.070 & -0.070 & $-0.425^{*}$ \\
\hline & $\begin{array}{c}(0.046) \\
-0.083^{*}\end{array}$ & $\begin{array}{l}(0.046) \\
-0.074^{*}\end{array}$ & $\begin{array}{l}(0.047) \\
-0.047\end{array}$ \\
\hline Income Quintile 1 & $\begin{array}{c}-0.083^{*} \\
(0.027)\end{array}$ & $\begin{array}{c}-0.074^{*} \\
(0.026)\end{array}$ & $\begin{array}{l}-0.047 \\
(0.025)\end{array}$ \\
\hline Income Quintile 2 & $\begin{array}{c}-0.061^{*} \\
(0.025)\end{array}$ & $\begin{array}{c}-0.052^{*} \\
(0.024)\end{array}$ & $\begin{array}{l}-0.042 \\
(0.023)\end{array}$ \\
\hline Income Quintile 4 & $\begin{array}{c}0.026 \\
(0.029)\end{array}$ & $\begin{array}{c}0.028 \\
(0.028)\end{array}$ & $\begin{array}{c}0.024 \\
(0.027)\end{array}$ \\
\hline Income Quintile 5 & $\begin{array}{c}0.012 \\
(0.039)\end{array}$ & $\begin{array}{c}0.040 \\
(0.038)\end{array}$ & $\begin{array}{c}0.006 \\
(0.037)\end{array}$ \\
\hline Employed & $\begin{array}{l}-0.019 \\
(0.022)\end{array}$ & $\begin{array}{l}-0.012 \\
(0.021)\end{array}$ & $\begin{array}{l}-0.009 \\
(0.020)\end{array}$ \\
\hline Public Income Source & $\begin{array}{l}-0.008 \\
(0.026)\end{array}$ & $\begin{array}{l}-0.018 \\
(0.025)\end{array}$ & $\begin{array}{l}-0.000 \\
(0.024)\end{array}$ \\
\hline Public Sector Experience & $\begin{array}{c}0.010 \\
(0.023)\end{array}$ & $\begin{array}{l}-0.007 \\
(0.022)\end{array}$ & $\begin{array}{l}-0.005 \\
(0.021)\end{array}$ \\
\hline Investments & $\begin{array}{c}-0.054^{*} \\
(0.023)\end{array}$ & $\begin{array}{l}-0.012 \\
(0.022)\end{array}$ & $\begin{array}{l}-0.035 \\
(0.022)\end{array}$ \\
\hline Own Home & $\begin{array}{l}-0.003 \\
(0.021)\end{array}$ & $\begin{array}{c}0.010 \\
(0.020)\end{array}$ & $\begin{array}{l}-0.009 \\
(0.020)\end{array}$ \\
\hline Mortgage & $\begin{array}{c}-0.048^{*} \\
(0.022)\end{array}$ & $\begin{array}{l}-0.032 \\
(0.021)\end{array}$ & $\begin{array}{l}-0.027 \\
(0.021)\end{array}$ \\
\hline HS Degree & $\begin{array}{l}0.060^{*} \\
(0.026)\end{array}$ & $\begin{array}{l}0.052^{*} \\
(0.025)\end{array}$ & $\begin{array}{c}0.026 \\
(0.025)\end{array}$ \\
\hline Bachelor's Degree & $\begin{array}{l}0.166^{*} \\
(0.033)\end{array}$ & $\begin{array}{l}0.139^{*} \\
(0.032)\end{array}$ & $\begin{array}{l}0.065^{*} \\
(0.032)\end{array}$ \\
\hline Graduate Degree & $\begin{array}{l}0.279^{*} \\
(0.032)\end{array}$ & $\begin{array}{l}0.246^{*} \\
(0.031)\end{array}$ & $\begin{array}{l}0.151^{*} \\
(0.031)\end{array}$ \\
\hline Female & $\begin{array}{l}0.071^{*} \\
(0.018)\end{array}$ & $\begin{array}{l}0.054^{*} \\
(0.018)\end{array}$ & $\begin{array}{l}0.051^{*} \\
(0.017)\end{array}$ \\
\hline Age $30-44$ & $\begin{array}{c}-0.072^{*} \\
(0.025)\end{array}$ & $\begin{array}{c}-0.055^{*} \\
(0.025)\end{array}$ & $\begin{array}{l}-0.027 \\
(0.024)\end{array}$ \\
\hline Age $45-64$ & $\begin{array}{l}0.069^{*} \\
(0.027)\end{array}$ & $\begin{array}{l}0.071^{*} \\
(0.026)\end{array}$ & $\begin{array}{l}0.076^{*} \\
(0.026)\end{array}$ \\
\hline Age $65+$ & $\begin{array}{l}0.098^{*} \\
(0.046)\end{array}$ & $\begin{array}{l}0.146^{*} \\
(0.045)\end{array}$ & $\begin{array}{l}0.136^{*} \\
(0.043)\end{array}$ \\
\hline \# Children & $\begin{array}{c}-0.041^{*} \\
(0.008)\end{array}$ & $\begin{array}{c}-0.036^{*} \\
(0.008)\end{array}$ & $\begin{array}{c}-0.025^{*} \\
(0.008)\end{array}$ \\
\hline Voted & $\begin{array}{c}-0.059^{*} \\
(0.025)\end{array}$ & $\begin{array}{c}-0.054^{*} \\
(0.025)\end{array}$ & $\begin{array}{c}-0.055^{*} \\
(0.025)\end{array}$ \\
\hline Far Left & & $\begin{array}{l}0.329^{*} \\
(0.025)\end{array}$ & $\begin{array}{l}0.283^{*} \\
(0.025)\end{array}$ \\
\hline Left & & $\begin{array}{l}0.229^{*} \\
(0.024)\end{array}$ & $\begin{array}{l}0.162^{*} \\
(0.024)\end{array}$ \\
\hline Right & & $\begin{array}{c}-0.121^{*} \\
(0.025)\end{array}$ & $\begin{array}{c}-0.138^{*} \\
(0.024)\end{array}$ \\
\hline Far Right & & $\begin{array}{c}-0.412^{*} \\
(0.030)\end{array}$ & $\begin{array}{c}-0.351^{*} \\
(0.030)\end{array}$ \\
\hline Pro-EU & & & $\begin{array}{l}0.507^{*} \\
(0.018)\end{array}$ \\
\hline High Empathy & & & $\begin{array}{l}0.058^{*} \\
(0.017)\end{array}$ \\
\hline Pro-Redistribution & & & $\begin{array}{l}0.067^{*} \\
(0.018)\end{array}$ \\
\hline High Knowledge & & & $\begin{array}{l}0.080^{*} \\
(0.018)\end{array}$ \\
\hline High Interest & & & $\begin{array}{c}-0.050^{*} \\
(0.021)\end{array}$ \\
\hline $\mathrm{R}^{2}$ & 0.046 & 0.099 & 0.156 \\
\hline Adj. $R^{2}$ & 0.044 & 0.097 & 0.154 \\
\hline Num. obs. & 12839 & 12839 & 12839 \\
\hline
\end{tabular}


Table C.8: Linear Regression - DV: Degree Opposed to Grexit (5-point Ordinal Version), by Country

\begin{tabular}{|c|c|c|c|c|c|c|c|c|c|c|c|c|}
\hline & France & France & France & Italy & Italy & Italy & Spain & Spain & Spain & UK & UK & UK \\
\hline (Intercept) & -0.108 & -0.156 & $-0.548^{*}$ & $-0.204^{*}$ & $-0.191^{*}$ & $-0.584^{*}$ & $0.192^{*}$ & 0.075 & $-0.365^{*}$ & -0.167 & $-0.199^{*}$ & $-0.448^{*}$ \\
\hline & $(0.084)$ & $(0.084)$ & $(0.085)$ & $(0.093)$ & $(0.094)$ & $(0.097)$ & $(0.081)$ & $(0.08$ & $(0.090)$ & $(0.100)$ & $(0.101)$ & $(0.105)$ \\
\hline Income Quintile 1 & $\begin{array}{l}-0.054 \\
(0.047)\end{array}$ & $\begin{array}{l}-0.059 \\
(0.046)\end{array}$ & $\begin{array}{l}-0.052 \\
(0.044)\end{array}$ & $\begin{array}{l}-0.088 \\
(0.052)\end{array}$ & $\begin{array}{l}-0.074 \\
(0.050)\end{array}$ & $\begin{array}{l}-0.041 \\
(0.048)\end{array}$ & $\begin{array}{l}-0.121^{*} \\
(0.052)\end{array}$ & $\begin{array}{l}-0.107^{*} \\
(0.052)\end{array}$ & $\begin{array}{l}-0.050 \\
(0.051)\end{array}$ & $\begin{array}{l}-0.067 \\
(0.065)\end{array}$ & $\begin{array}{l}-0.059 \\
(0.063)\end{array}$ & $\begin{array}{l}-0.041 \\
(0.062)\end{array}$ \\
\hline Income Quintile 2 & $\begin{array}{l}-0.009 \\
(0.050)\end{array}$ & $\begin{array}{c}0.001 \\
(0.048)\end{array}$ & $\begin{array}{c}0.003 \\
(0.046)\end{array}$ & $\begin{array}{l}-0.081 \\
(0.050)\end{array}$ & $\begin{array}{l}-0.082 \\
(0.048)\end{array}$ & $\begin{array}{l}-0.067 \\
(0.046)\end{array}$ & $\begin{array}{l}-0.039 \\
(0.043)\end{array}$ & $\begin{array}{l}-0.028 \\
(0.042)\end{array}$ & $\begin{array}{l}-0.009 \\
(0.041)\end{array}$ & $\begin{array}{l}-0.192^{*} \\
(0.060)\end{array}$ & $\begin{array}{l}-0.167^{*} \\
(0.059)\end{array}$ & $\begin{array}{l}-0.155^{*} \\
(0.057)\end{array}$ \\
\hline Income Quintile 4 & $\begin{array}{l}0.014 \\
(0.052)\end{array}$ & $\begin{array}{l}0.036 \\
(0.050)\end{array}$ & $\begin{array}{l}0.005 \\
(0.047)\end{array}$ & $\begin{array}{c}0.074 \\
(0.060)\end{array}$ & $\begin{array}{c}0.059 \\
(0.058)\end{array}$ & $\begin{array}{l}0.070 \\
(0.056)\end{array}$ & $\begin{array}{c}0.018 \\
(0.059)\end{array}$ & $\begin{array}{c}0.028 \\
(0.058)\end{array}$ & $\begin{array}{r}0.029 \\
(0.057)\end{array}$ & $\begin{array}{l}-0.052 \\
(0.064)\end{array}$ & $\begin{array}{l}-0.063 \\
(0.063)\end{array}$ & $\begin{array}{l}-0.064 \\
(0.061)\end{array}$ \\
\hline Income Quintile 5 & 0.060 & 0.101 & 0.013 & 0.030 & 0.034 & 0.007 & -0.017 & 0.023 & 0.030 & -0.081 & -0.075 & -0.084 \\
\hline & $(0.073)$ & $(0.070)$ & $(0.066)$ & $(0.086)$ & $(0.083)$ & $(0.080)$ & $(0.079)$ & $(0.076)$ & $(0.075)$ & $(0.078)$ & $(0.076)$ & $(0.073)$ \\
\hline Employed & $\begin{array}{l}-0.046 \\
(0.042)\end{array}$ & $\begin{array}{l}-0.033 \\
(0.040)\end{array}$ & $\begin{array}{l}-0.009 \\
(0.039)\end{array}$ & $\begin{array}{c}0.027 \\
(0.042)\end{array}$ & $\begin{array}{c}0.012 \\
(0.041)\end{array}$ & $\begin{array}{c}0.011 \\
(0.039)\end{array}$ & $\begin{array}{l}-0.077 \\
(0.040)\end{array}$ & $\begin{array}{l}-0.065 \\
(0.040)\end{array}$ & $\begin{array}{l}-0.075 \\
(0.039)\end{array}$ & $\begin{array}{c}0.029 \\
(0.053)\end{array}$ & $\begin{array}{c}0.058 \\
(0.052)\end{array}$ & $\begin{array}{c}0.063 \\
(0.049)\end{array}$ \\
\hline Public Income Source & $\begin{array}{c}0.014 \\
(0.050)\end{array}$ & $\begin{array}{l}-0.005 \\
(0.048)\end{array}$ & $\begin{array}{c}0.018 \\
(0.046)\end{array}$ & $\begin{array}{c}0.019 \\
(0.050)\end{array}$ & $\begin{array}{l}-0.018 \\
(0.048)\end{array}$ & $\begin{array}{l}-0.004 \\
(0.046)\end{array}$ & $\begin{array}{l}-0.062 \\
(0.051)\end{array}$ & $\begin{array}{l}-0.061 \\
(0.050)\end{array}$ & $\begin{array}{l}-0.062 \\
(0.049)\end{array}$ & $\begin{array}{l}-0.060 \\
(0.060)\end{array}$ & $\begin{array}{l}-0.020 \\
(0.058)\end{array}$ & $\begin{array}{c}0.006 \\
(0.055)\end{array}$ \\
\hline Public Sector Experience & $\begin{array}{c}0.006 \\
(0.042)\end{array}$ & $\begin{array}{l}-0.033 \\
(0.041)\end{array}$ & $\begin{array}{l}-0.018 \\
(0.039)\end{array}$ & $\begin{array}{l}-0.041 \\
(0.049)\end{array}$ & $\begin{array}{l}-0.048 \\
(0.048)\end{array}$ & $\begin{array}{l}-0.057 \\
(0.046)\end{array}$ & $\begin{array}{c}0.045 \\
(0.042)\end{array}$ & $\begin{array}{l}0.036 \\
(0.041)\end{array}$ & $\begin{array}{c}0.049 \\
(0.039)\end{array}$ & $\begin{array}{l}0.066 \\
(0.048)\end{array}$ & $\begin{array}{c}0.045 \\
(0.047)\end{array}$ & $\begin{array}{l}0.047 \\
(0.045)\end{array}$ \\
\hline Investments & $\begin{array}{l}-0.006 \\
(0.045)\end{array}$ & $\begin{array}{l}0.040 \\
(0.044)\end{array}$ & $\begin{array}{c}0.013 \\
(0.043)\end{array}$ & $\begin{array}{l}-0.024 \\
(0.043)\end{array}$ & $\begin{array}{l}-0.000 \\
(0.041)\end{array}$ & $\begin{array}{l}-0.027 \\
(0.040)\end{array}$ & $\begin{array}{l}-0.066 \\
(0.044)\end{array}$ & $\begin{array}{l}-0.034 \\
(0.043)\end{array}$ & $\begin{array}{l}-0.034 \\
(0.042)\end{array}$ & $\begin{array}{l}-0.176^{*} \\
(0.054)\end{array}$ & $\begin{array}{l}-0.084 \\
(0.053)\end{array}$ & $\begin{array}{l}-0.116^{*} \\
(0.052)\end{array}$ \\
\hline Own Home & $\begin{array}{l}-0.052 \\
(0.037)\end{array}$ & $\begin{array}{l}-0.043 \\
(0.035)\end{array}$ & $\begin{array}{l}-0.055 \\
(0.034)\end{array}$ & $\begin{array}{l}0.084^{*} \\
(0.042)\end{array}$ & $\begin{array}{l}0.102^{*} \\
(0.041)\end{array}$ & $\begin{array}{l}0.071 \\
(0.040)\end{array}$ & $\begin{array}{l}-0.013 \\
(0.040)\end{array}$ & $\begin{array}{l}-0.005 \\
(0.039)\end{array}$ & $\begin{array}{l}-0.030 \\
(0.039)\end{array}$ & $\begin{array}{l}0.031 \\
(0.053)\end{array}$ & $\begin{array}{l}0.055 \\
(0.052)\end{array}$ & $\begin{array}{l}0.025 \\
(0.050)\end{array}$ \\
\hline Mortgage & $\begin{array}{l}-0.024 \\
(0.055)\end{array}$ & $\begin{array}{l}-0.004 \\
(0.053)\end{array}$ & $\begin{array}{l}0.030 \\
(0.051)\end{array}$ & $\begin{array}{l}0.002 \\
(0.041)\end{array}$ & $\begin{array}{l}0.016 \\
(0.039)\end{array}$ & $\begin{array}{l}0.017 \\
(0.038)\end{array}$ & $\begin{array}{l}-0.095^{*} \\
(0.037)\end{array}$ & $\begin{array}{l}-0.085^{*} \\
(0.036)\end{array}$ & $\begin{array}{l}-0.068 \\
(0.035)\end{array}$ & $\begin{array}{l}-0.124^{*} \\
(0.054)\end{array}$ & $\begin{array}{l}-0.102 \\
(0.053)\end{array}$ & $\begin{array}{l}-0.099^{*} \\
(0.050)\end{array}$ \\
\hline HS Degree & $\begin{array}{l}0.094 \\
(0.057)\end{array}$ & $\begin{array}{c}0.099 \\
(0.056)\end{array}$ & $\begin{array}{c}0.064 \\
(0.054)\end{array}$ & $\begin{array}{c}0.102 \\
(0.054)\end{array}$ & $\begin{array}{l}0.100 \\
(0.053)\end{array}$ & $\begin{array}{l}0.076 \\
0.052)\end{array}$ & $\begin{array}{l}0.113^{*} \\
(0.049)\end{array}$ & $\begin{array}{l}0.082 \\
(0.049)\end{array}$ & $\begin{array}{c}0.049 \\
(0.048)\end{array}$ & $\begin{array}{c}0.010 \\
(0.048\end{array}$ & $\begin{array}{l}0.019 \\
(0.047)\end{array}$ & $\begin{array}{l}0.017 \\
(0.046)\end{array}$ \\
\hline & (0.057) & $(0.056)$ & $(0.054)$ & $(0.054)$ & $\begin{array}{l}(0.053) \\
0.186^{*}\end{array}$ & $(0.052)$ & $(0.049)$ & $(0.049)$ & $(0.048)$ & $(0.048)$ & $(0.047)$ & $(0.046)$ \\
\hline Bachelor's Degree & $\begin{array}{l}0.299^{*} \\
(0.080)\end{array}$ & $\begin{array}{l}0.295^{*} \\
(0.077)\end{array}$ & $\begin{array}{l}0.192^{*} \\
(0.074)\end{array}$ & $\begin{array}{l}0.203^{*} \\
(0.072)\end{array}$ & $\begin{array}{l}0.186^{*} \\
(0.071)\end{array}$ & $\begin{array}{l}0.147^{*} \\
(0.070)\end{array}$ & $\begin{array}{l}0.151^{*} \\
(0.056)\end{array}$ & $\begin{array}{l}0.113^{*} \\
(0.055)\end{array}$ & $\begin{array}{c}0.031 \\
(0.055)\end{array}$ & $\begin{array}{l}0.127^{*} \\
(0.064)\end{array}$ & $\begin{array}{c}0.089 \\
(0.062)\end{array}$ & $\begin{array}{c}0.050 \\
(0.061)\end{array}$ \\
\hline Graduate Degree & $\begin{array}{l}0.489^{*} \\
(0.071)\end{array}$ & $\begin{array}{l}0.443^{*} \\
(0.070)\end{array}$ & $\begin{array}{l}0.293^{*} \\
(0.067)\end{array}$ & $\begin{array}{l}0.273^{*} \\
(0.064)\end{array}$ & $\begin{array}{l}0.239^{*} \\
(0.062)\end{array}$ & $\begin{array}{l}0.170^{*} \\
(0.062)\end{array}$ & $\begin{array}{l}0.221^{*} \\
(0.054)\end{array}$ & $\begin{array}{l}0.194^{*} \\
(0.054)\end{array}$ & $\begin{array}{l}0.097 \\
(0.053)\end{array}$ & $\begin{array}{l}0.099 \\
(0.095)\end{array}$ & $\begin{array}{l}0.078 \\
(0.090)\end{array}$ & $\begin{array}{l}0.027 \\
(0.087)\end{array}$ \\
\hline Female & $\begin{array}{l}0.095^{*} \\
(0.034)\end{array}$ & $\begin{array}{l}0.070^{*} \\
(0.033)\end{array}$ & $\begin{array}{l}0.080^{*} \\
(0.032)\end{array}$ & $\begin{array}{l}0.080^{*} \\
(0.036)\end{array}$ & $\begin{array}{c}0.052 \\
(0.035)\end{array}$ & $\begin{array}{c}0.028 \\
(0.035)\end{array}$ & $\begin{array}{c}0.007 \\
(0.032)\end{array}$ & $\begin{array}{c}0.004 \\
(0.032)\end{array}$ & $\begin{array}{c}0.030 \\
(0.032)\end{array}$ & $\begin{array}{l}0.128^{*} \\
(0.043)\end{array}$ & $\begin{array}{l}0.112^{*} \\
(0.042)\end{array}$ & $\begin{array}{l}0.090^{*} \\
(0.041)\end{array}$ \\
\hline Age $30-44$ & $\begin{array}{l}-0.020 \\
(0.045)\end{array}$ & $\begin{array}{l}-0.023 \\
(0.043)\end{array}$ & $\begin{array}{c}0.025 \\
(0.042)\end{array}$ & $\begin{array}{l}-0.064 \\
(0.051)\end{array}$ & $\begin{array}{l}-0.026 \\
(0.050)\end{array}$ & $\begin{array}{l}-0.006 \\
(0.049)\end{array}$ & $\begin{array}{l}-0.066 \\
(0.045)\end{array}$ & $\begin{array}{l}-0.052 \\
(0.044)\end{array}$ & $\begin{array}{l}-0.049 \\
(0.044)\end{array}$ & $\begin{array}{l}-0.043 \\
(0.071)\end{array}$ & $\begin{array}{l}-0.033 \\
(0.069)\end{array}$ & $\begin{array}{c}0.004 \\
(0.069)\end{array}$ \\
\hline Age $45-64$ & $\begin{array}{c}0.058 \\
(0.048)\end{array}$ & $\begin{array}{c}0.045 \\
(0.046)\end{array}$ & $\begin{array}{l}0.091^{*} \\
(0.045)\end{array}$ & $\begin{array}{l}0.198^{*} \\
(0.055)\end{array}$ & $\begin{array}{l}0.212^{*} \\
(0.054)\end{array}$ & $\begin{array}{l}0.179^{*} \\
(0.053)\end{array}$ & $\begin{array}{c}0.001 \\
(0.050)\end{array}$ & $\begin{array}{c}0.008 \\
(0.049)\end{array}$ & $\begin{array}{l}-0.035 \\
(0.050)\end{array}$ & $\begin{array}{c}0.054 \\
(0.071)\end{array}$ & $\begin{array}{c}0.029 \\
(0.069)\end{array}$ & $\begin{array}{c}0.100 \\
(0.069)\end{array}$ \\
\hline ge $65+$ & $\begin{array}{c}0.148 \\
(0.076)\end{array}$ & $\begin{array}{l}0.214^{*} \\
(0.074)\end{array}$ & $\begin{array}{l}0.219^{*} \\
(0.071)\end{array}$ & $\begin{array}{l}0.439^{*} \\
(0.108)\end{array}$ & $\begin{array}{l}0.474^{*} \\
(0.104)\end{array}$ & $\begin{array}{l}0.444^{*} \\
(0.097)\end{array}$ & $\begin{array}{l}-0.046 \\
(0.193)\end{array}$ & $\begin{array}{l}-0.031 \\
(0.184)\end{array}$ & $\begin{array}{l}-0.091 \\
(0.184)\end{array}$ & $\begin{array}{l}-0.015 \\
(0.094)\end{array}$ & $\begin{array}{l}-0.015 \\
(0.092)\end{array}$ & $\begin{array}{c}0.047 \\
(0.091)\end{array}$ \\
\hline \# Children & $-0.051^{*}$ & $-0.050^{*}$ & $-0.034^{*}$ & $-0.063^{*}$ & $-0.060^{*}$ & $-0.047^{*}$ & -0.020 & -0.009 & 0.001 & -0.009 & -0.007 & 0.004 \\
\hline Voted & $\begin{array}{c}(0.013) \\
-0.110^{*}\end{array}$ & $\begin{array}{c}(0.013) \\
-0.109^{*}\end{array}$ & $\begin{array}{c}(0.013) \\
-0.100^{*}\end{array}$ & $\begin{array}{c}(0.019) \\
0.021\end{array}$ & $\begin{array}{l}(0.019) \\
-0.020\end{array}$ & $\begin{array}{l}(0.018) \\
-0.051\end{array}$ & $\begin{array}{c}(0.018) \\
0.041\end{array}$ & $\begin{array}{c}(0.018) \\
0.049\end{array}$ & $\begin{array}{c}(0.017) \\
0.012\end{array}$ & $\begin{array}{c}(0.014) \\
-0.169^{*}\end{array}$ & $\begin{array}{c}(0.014) \\
-0.122^{*}\end{array}$ & $\begin{array}{l}(0.014) \\
-0.073\end{array}$ \\
\hline Far Left & $(0.048)$ & $\begin{array}{l}(0.047) \\
0.501^{*}\end{array}$ & $\begin{array}{l}(0.046) \\
0.406^{*}\end{array}$ & $(0.058)$ & $\begin{array}{l}(0.058) \\
0.337^{*}\end{array}$ & $\begin{array}{l}(0.057) \\
0.255^{*}\end{array}$ & $(0.048)$ & $\begin{array}{l}(0.048) \\
0.234^{*}\end{array}$ & $\begin{array}{l}(0.047) \\
0.215^{*} \\
(0.044)\end{array}$ & $(0.051)$ & $\begin{array}{l}(0.050) \\
0.251^{*} \\
(0.067)\end{array}$ & $\begin{array}{c}(0.049) \\
0.227^{*} \\
(0.069)\end{array}$ \\
\hline Left & & $\begin{array}{l}(0.049) \\
0.280^{*}\end{array}$ & $\begin{array}{l}(0.048) \\
0.207^{*}\end{array}$ & & $\begin{array}{l}(0.051) \\
0.255^{*}\end{array}$ & $\begin{array}{l}(0.050) \\
0.160^{*}\end{array}$ & & $\begin{array}{l}(0.043) \\
0.225^{*}\end{array}$ & $\begin{array}{l}(0.044) \\
0.185^{*}\end{array}$ & & $\begin{array}{c}(0.067) \\
0.080\end{array}$ & $\begin{array}{c}(0.069) \\
0.043\end{array}$ \\
\hline & & $(0.047)$ & $(0.045)$ & & $(0.049)$ & $(0.047)$ & & $(0.043)$ & $(0.042)$ & & $(0.058)$ & $(0.058)$ \\
\hline Right & & $\begin{array}{l}-0.032 \\
(0.044)\end{array}$ & $\begin{array}{l}-0.072 \\
(0.043)\end{array}$ & & $\begin{array}{c}-0.154^{*} \\
(0.049)\end{array}$ & $\begin{array}{c}-0.147^{*} \\
(0.048)\end{array}$ & & $\begin{array}{c}-0.153^{*} \\
(0.053)\end{array}$ & $\begin{array}{c}-0.172^{*} \\
(0.052)\end{array}$ & & $\begin{array}{c}-0.176^{*} \\
(0.054)\end{array}$ & $\begin{array}{c}-0.156^{*} \\
(0.052)\end{array}$ \\
\hline Far Right & & $\begin{array}{c}-0.350^{*} \\
(0.048)\end{array}$ & $\begin{array}{c}-0.294^{*} \\
(0.046)\end{array}$ & & $\begin{array}{c}-0.426^{*} \\
(0.057)\end{array}$ & $\begin{array}{c}-0.314^{*} \\
(0.057)\end{array}$ & & $\begin{array}{c}-0.282^{*} \\
(0.077)\end{array}$ & $\begin{array}{c}-0.294^{*} \\
(0.076)\end{array}$ & & $\begin{array}{c}-0.527^{*} \\
(0.071)\end{array}$ & $\begin{array}{c}-0.434^{*} \\
(0.072)\end{array}$ \\
\hline Pro-EU & & & $0.596^{*}$ & & (0.00\%) & $0.532^{*}$ & & (0.07) & $\begin{array}{l}0.429^{*} \\
(0.035)\end{array}$ & & $(0.071)$ & $0.430^{*}$ \\
\hline High Empathy & & & $\begin{array}{l}(0.032) \\
0.063^{*}\end{array}$ & & & $\begin{array}{l}(0.036) \\
-0.003\end{array}$ & & & $\begin{array}{l}(0.035) \\
0.107^{*}\end{array}$ & & & $\begin{array}{l}(0.040) \\
0.026\end{array}$ \\
\hline 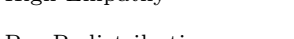 & & & $(0.031)$ & & & $(0.035)$ & & & $(0.033)$ & & & $(0.040)$ \\
\hline Pro-Redistribution & & & 0.029 & & & $0.105^{*}$ & & & $0.135^{*}$ & & & -0.017 \\
\hline & & & $(0.031)$ & & & $(0.035)$ & & & $(0.036)$ & & & $(0.041)$ \\
\hline High Knowledge & & & $\begin{array}{c}0.039 \\
(0.031)\end{array}$ & & & $\begin{array}{l}0.174^{*} \\
(0.035)\end{array}$ & & & $\begin{array}{c}0.056 \\
(0.036)\end{array}$ & & & $\begin{array}{c}0.028 \\
(0.043)\end{array}$ \\
\hline High Interest & & & $\begin{array}{c}0.006 \\
(0.042)\end{array}$ & & & $\begin{array}{c}-0.108^{*} \\
(0.038)\end{array}$ & & & $\begin{array}{l}0.077^{*} \\
(0.039)\end{array}$ & & & $\begin{array}{l}-0.228^{*} \\
(0.047)\end{array}$ \\
\hline $\mathrm{R}^{2}$ & 0.034 & 0.104 & 0.182 & 0.030 & 0.0 & 0.155 & 0.015 & 0.047 & 0.094 & 0.033 & 0.088 & 0.147 \\
\hline Adj. $\mathrm{R}$ & 0.030 & 0.099 & 0.1 & 0.025 & 0.08 & 0.1 & 0.0 & 0.041 & 0.087 & 0.024 & 0.077 & 0.135 \\
\hline Num. obs. & 3886 & 3886 & 3886 & 3473 & 3473 & 3473 & 3471 & 3471 & 3471 & 2009 & 2009 & 2009 \\
\hline
\end{tabular}


Table C.9: Coefficients from Main Linear Probability Model (Model 2 in Table C.1) vs. Average Effects Estimated by Logit and Probit Models with Same Regressors

\begin{tabular}{lrrr}
\hline Ideology & LPM Coefficients & Logit Average Effects & Probit Average Effects \\
\hline Far Left & 0.12773 & 0.12748 & 0.12717 \\
Left & 0.10544 & 0.10476 & 0.10501 \\
Right & -0.06975 & -0.07067 & -0.07070 \\
Far Right & -0.17849 & -0.17917 & -0.17946 \\
\hline
\end{tabular}

Table C.10: Linear Probability Model - DV: Probability of Being Opposed to Grexit - Robustness Check with Pairwise Interactions between all Covariates

\begin{tabular}{lccccc}
\hline & Full & France & Italy & Spain & UK \\
\hline Far Left & $0.125^{*}$ & $0.179^{*}$ & $0.107^{*}$ & $0.071^{*}$ & $0.191^{*}$ \\
& $(0.012)$ & $(0.023)$ & $(0.024)$ & $(0.022)$ & $(0.037)$ \\
Left & $0.102^{*}$ & $0.119^{*}$ & $0.081^{*}$ & $0.084^{*}$ & $0.109^{*}$ \\
& $(0.013)$ & $(0.024)$ & $(0.024)$ & $(0.023)$ & $(0.032)$ \\
Right & $-0.070^{*}$ & -0.022 & $-0.104^{*}$ & $-0.100^{*}$ & $-0.063^{*}$ \\
& $(0.013)$ & $(0.023)$ & $(0.025)$ & $(0.028)$ & $(0.029)$ \\
Far Right & $-0.176^{*}$ & $-0.172^{*}$ & $-0.208^{*}$ & $-0.125^{*}$ & $-0.163^{*}$ \\
& $(0.014)$ & $(0.023)$ & $(0.026)$ & $(0.038)$ & $(0.031)$ \\
& & & & & \\
Economic, Demographic, & $\checkmark$ & $\checkmark$ & $\checkmark$ & $\checkmark$ & $\checkmark$ \\
Additional Controls & & & & & \\
Pairwise Interactions between & $\checkmark$ & $\checkmark$ & $\checkmark$ & $\checkmark$ & $\checkmark$ \\
All Controls & & & & & \\
\hline $\mathrm{R}^{2}$ & 0.088 & 0.096 & 0.100 & 0.051 & 0.116 \\
Adj. R ${ }^{2}$ & 0.082 & 0.076 & 0.079 & 0.028 & 0.078 \\
Num. obs. & 12839 & 3886 & 3473 & 3471 & 2009 \\
\hline * & & & & &
\end{tabular}


Table C.11: Linear Probability Model - DV: Probability of Being Opposed to Grexit, Full Sample, with Alternative Coding of Ideology Bins

\begin{tabular}{|c|c|c|c|}
\hline & Model 1 & Model 2 & Model 3 \\
\hline (Intercept) & $\begin{array}{l}0.532^{*} \\
(0.024)\end{array}$ & $\begin{array}{l}0.543^{*} \\
(0.024)\end{array}$ & $0.351^{*}$ \\
\hline \multirow{2}{*}{ Income Quintile 1} & $-0.037^{*}$ & $-0.034^{*}$ & -0.020 \\
\hline & $(0.013)$ & $(0.013)$ & $(0.013)$ \\
\hline \multirow[t]{2}{*}{ Income Quintile 2} & -0.014 & -0.010 & -0.005 \\
\hline & $(0.012)$ & $(0.012)$ & $(0.012)$ \\
\hline \multirow[t]{2}{*}{ Income Quintile 4} & 0.002 & 0.004 & 0.002 \\
\hline & $(0.015)$ & $(0.014)$ & $(0.014)$ \\
\hline \multirow[t]{2}{*}{ Income Quintile 5} & -0.015 & -0.003 & -0.020 \\
\hline & $(0.018)$ & $(0.018)$ & $(0.017)$ \\
\hline \multirow[t]{2}{*}{ Employed } & -0.014 & -0.011 & -0.009 \\
\hline & $(0.011)$ & $(0.011)$ & $(0.010)$ \\
\hline \multirow[t]{2}{*}{ Public Income Source } & -0.007 & -0.011 & -0.001 \\
\hline & $(0.013)$ & $(0.013)$ & $(0.012)$ \\
\hline \multirow[t]{2}{*}{ Public Sector Experience } & 0.009 & 0.002 & 0.003 \\
\hline & $(0.011)$ & $(0.011)$ & $(0.010)$ \\
\hline \multirow{2}{*}{ Investments } & -0.016 & 0.002 & -0.010 \\
\hline & $(0.011)$ & $(0.011)$ & $(0.011)$ \\
\hline \multirow[t]{2}{*}{ Own Home } & 0.013 & 0.019 & 0.008 \\
\hline & $(0.010)$ & $(0.010)$ & $(0.010)$ \\
\hline \multirow[t]{2}{*}{ Mortgage } & $-0.024^{*}$ & -0.018 & -0.016 \\
\hline & $(0.011)$ & $(0.011)$ & $(0.010)$ \\
\hline \multirow[t]{2}{*}{ HS Degree } & $0.037^{*}$ & $0.033^{*}$ & 0.021 \\
\hline & $(0.014)$ & $(0.013)$ & $(0.013)$ \\
\hline \multirow[t]{2}{*}{ Bachelor's Degree } & $0.076^{*}$ & $0.062^{*}$ & 0.026 \\
\hline & $(0.017)$ & $(0.017)$ & $(0.016)$ \\
\hline Graduate Degree & $\begin{array}{l}0.133^{*} \\
(0.016)\end{array}$ & $\begin{array}{l}0.118^{*} \\
(0.016)\end{array}$ & $\begin{array}{l}0.071^{*} \\
(0.016)\end{array}$ \\
\hline \multirow{2}{*}{ Female } & $\begin{array}{l}(0.016) \\
0.043^{*}\end{array}$ & $\begin{array}{l}(0.016) \\
0.036^{*}\end{array}$ & $\begin{array}{l}(0.016) \\
0.032^{*}\end{array}$ \\
\hline & $(0.009)$ & $(0.009)$ & $(0.009)$ \\
\hline \multirow[t]{2}{*}{ Age $30-44$} & $-0.028^{*}$ & -0.021 & -0.006 \\
\hline & $(0.013)$ & $(0.013)$ & $(0.012)$ \\
\hline \multirow[t]{2}{*}{ Age $45-64$} & 0.016 & 0.017 & 0.020 \\
\hline & $(0.013)$ & $(0.013)$ & $(0.013)$ \\
\hline \multirow[t]{2}{*}{ Age $65+$} & 0.019 & 0.038 & 0.035 \\
\hline & $(0.022)$ & $(0.022)$ & $(0.021)$ \\
\hline \multirow[t]{2}{*}{ \# Children } & $-0.017^{*}$ & $-0.014^{*}$ & $-0.008^{*}$ \\
\hline & $(0.004)$ & $(0.004)$ & $(0.004)$ \\
\hline Voted & -0.017 & -0.013 & -0.011 \\
\hline & $(0.014)$ & $(0.014)$ & $(0.013)$ \\
\hline Far Left & & $0.102^{*}$ & $0.108^{*}$ \\
\hline & & $(0.014)$ & $(0.014)$ \\
\hline Left & & $\begin{array}{l}0.128^{*} \\
(0.011)\end{array}$ & $\begin{array}{c}0.099^{*} \\
(0.011)\end{array}$ \\
\hline Right & & $-0.131^{*}$ & $-0.119^{*}$ \\
\hline & & $(0.013)$ & $(0.012)$ \\
\hline Far Right & & $-0.207^{*}$ & $-0.146^{*}$ \\
\hline & & $(0.016)$ & $(0.016)$ \\
\hline Pro-EU & & & $0.269^{*}$ \\
\hline High Empathy & & & $\begin{array}{l}(0.009) \\
0.030^{*}\end{array}$ \\
\hline & & & $(0.009)$ \\
\hline Pro-Redistribution & & & $0.030^{*}$ \\
\hline High Knowledge & & & $\begin{array}{l}(0.009) \\
0.041^{*}\end{array}$ \\
\hline & & & $(0.009)$ \\
\hline High Interest & & & $-0.049^{*}$ \\
\hline & & & $(0.009)$ \\
\hline $\mathrm{R}^{2}$ & 0.042 & 0.081 & 0.148 \\
\hline Adj. $R^{2}$ & 0.041 & 0.079 & 0.146 \\
\hline Num. obs. & 12839 & 12839 & 12839 \\
\hline
\end{tabular}


Table C.12: Linear Probability Model - DV: Probability of Being Opposed to Grexit, by Country, with Alternative Coding of Ideology Bins

\begin{tabular}{|c|c|c|c|c|c|c|c|c|c|c|c|c|}
\hline & France & France & France & Italy & Italy & Italy & Spain & Spain & Spain & UK & UK & UK \\
\hline (Intercept) & $\begin{array}{l}0.520^{*} \\
(0.043)\end{array}$ & $0.520^{*}$ & $0.317^{*}$ & $0.442^{*}$ & $0.464^{*}$ & $0.246^{*}$ & $0.653^{*}$ & $0.615^{*}$ & $0.411^{*}$ & $0.438^{*}$ & $0.404^{*}$ & $0.233^{*}$ \\
\hline Income Quintile 1 & $\begin{array}{l}(0.043) \\
-0.013\end{array}$ & $\begin{array}{l}(0.043) \\
-0.015\end{array}$ & $\begin{array}{l}(0.044) \\
-0.011\end{array}$ & $\begin{array}{l}(0.048) \\
-0.041\end{array}$ & $\begin{array}{l}(0.048) \\
-0.039\end{array}$ & $\begin{array}{l}(0.049) \\
-0.018\end{array}$ & $\begin{array}{l}(0.043) \\
-0.083^{*}\end{array}$ & $\begin{array}{l}(0.044) \\
-0.080^{*}\end{array}$ & $\begin{array}{l}(0.048) \\
-0.054^{*}\end{array}$ & $\begin{array}{l}(0.056) \\
-0.011\end{array}$ & $\begin{array}{l}(0.056) \\
-0.005\end{array}$ & $\begin{array}{l}(0.058) \\
0.004\end{array}$ \\
\hline 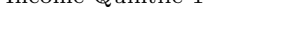 & $(0.023)$ & $(0.023)$ & $(0.022)$ & $(0.025)$ & $(0.024)$ & $(0.023)$ & $(0.027)$ & $(0.027)$ & $(0.026)$ & $(0.035)$ & $(0.034)$ & $(0.033)$ \\
\hline Income Quintile 2 & $\begin{array}{l}0.020 \\
(0.024)\end{array}$ & $\begin{array}{l}0.025 \\
(0.024)\end{array}$ & $\begin{array}{l}0.026 \\
(0.023)\end{array}$ & $\begin{array}{l}-0.030 \\
(0.024)\end{array}$ & -0.032 & $\begin{array}{l}-0.021 \\
(0.022)\end{array}$ & -0.023 & -0.019 & -0.011 & -0.040 & -0.027 & -0.021 \\
\hline Income Quintile 4 & 0.008 & 0.020 & 0.004 & -0.005 & -0.014 & -0.004 & -0.007 & $\begin{array}{l}(0.021) \\
-0.000\end{array}$ & $\begin{array}{c}(0.020) \\
0.004\end{array}$ & -0.002 & $\begin{array}{l}(0.032) \\
-0.003\end{array}$ & $\begin{array}{l}(0.031) \\
-0.005\end{array}$ \\
\hline & $(0.026)$ & $(0.025)$ & $(0.024)$ & $(0.028)$ & $(0.028)$ & $(0.026)$ & $(0.029)$ & $(0.029)$ & $(0.029)$ & $(0.035)$ & $(0.035)$ & $(0.033)$ \\
\hline Income Quintile 5 & $\begin{array}{c}0.007 \\
(0.033)\end{array}$ & $\begin{array}{c}0.030 \\
(0.032)\end{array}$ & $\begin{array}{l}-0.015 \\
(0.030)\end{array}$ & $\begin{array}{l}-0.029 \\
(0.038)\end{array}$ & $\begin{array}{l}-0.027 \\
(0.037)\end{array}$ & $\begin{array}{l}-0.042 \\
(0.036)\end{array}$ & $\begin{array}{l}-0.054 \\
(0.037)\end{array}$ & $\begin{array}{l}-0.033 \\
(0.036)\end{array}$ & $\begin{array}{l}-0.024 \\
(0.036)\end{array}$ & $\begin{array}{l}-0.021 \\
(0.041)\end{array}$ & $\begin{array}{l}-0.021 \\
(0.040)\end{array}$ & $\begin{array}{l}-0.026 \\
(0.038)\end{array}$ \\
\hline Employed & $\begin{array}{l}-0.015 \\
(0.021)\end{array}$ & $\begin{array}{l}-0.012 \\
(0.020)\end{array}$ & $\begin{array}{c}0.001 \\
(0.020)\end{array}$ & $\begin{array}{l}0.006 \\
(0.021)\end{array}$ & $\begin{array}{l}0.004 \\
(0.020)\end{array}$ & $\begin{array}{c}0.004 \\
(0.019)\end{array}$ & $\begin{array}{l}-0.020 \\
(0.021)\end{array}$ & $\begin{array}{l}-0.015 \\
(0.021)\end{array}$ & $\begin{array}{l}-0.023 \\
(0.020)\end{array}$ & $\begin{array}{l}-0.047 \\
(0.029)\end{array}$ & $\begin{array}{l}-0.032 \\
(0.029)\end{array}$ & $\begin{array}{l}-0.027 \\
(0.027)\end{array}$ \\
\hline Public Income Source & $\begin{array}{c}0.003 \\
(0.025)\end{array}$ & $\begin{array}{l}-0.003 \\
(0.024)\end{array}$ & $\begin{array}{l}0.008 \\
(0.024)\end{array}$ & $\begin{array}{l}0.014 \\
(0.024)\end{array}$ & $\begin{array}{l}-0.001 \\
(0.023)\end{array}$ & $\begin{array}{l}0.009 \\
(0.022)\end{array}$ & $\begin{array}{l}-0.013 \\
(0.026)\end{array}$ & $\begin{array}{l}-0.010 \\
(0.026)\end{array}$ & $\begin{array}{l}-0.010 \\
(0.025)\end{array}$ & $\begin{array}{l}-0.060 \\
(0.032)\end{array}$ & $\begin{array}{l}-0.047 \\
(0.032)\end{array}$ & $\begin{array}{l}-0.033 \\
(0.030)\end{array}$ \\
\hline Public Sector Experience & $\begin{array}{l}0.005 \\
(0.021)\end{array}$ & $\begin{array}{l}-0.010 \\
(0.020)\end{array}$ & $\begin{array}{l}-0.002 \\
(0.019)\end{array}$ & $\begin{array}{l}0.001 \\
(0.023)\end{array}$ & $\begin{array}{l}-0.003 \\
(0.022)\end{array}$ & $\begin{array}{l}-0.009 \\
(0.021)\end{array}$ & $\begin{array}{l}-0.007 \\
(0.021)\end{array}$ & $\begin{array}{l}-0.009 \\
(0.020)\end{array}$ & $\begin{array}{l}-0.002 \\
(0.020)\end{array}$ & $\begin{array}{l}0.058^{*} \\
(0.025)\end{array}$ & $\begin{array}{l}0.048 \\
(0.025)\end{array}$ & $\begin{array}{l}0.047^{*} \\
(0.024)\end{array}$ \\
\hline Investments & $\begin{array}{c}0.007 \\
(0.022)\end{array}$ & $\begin{array}{c}0.030 \\
(0.021)\end{array}$ & $\begin{array}{c}0.016 \\
(0.021)\end{array}$ & $\begin{array}{l}-0.020 \\
(0.020)\end{array}$ & $\begin{array}{l}-0.009 \\
(0.019)\end{array}$ & $\begin{array}{l}-0.024 \\
(0.019)\end{array}$ & $\begin{array}{l}-0.029 \\
(0.022)\end{array}$ & $\begin{array}{l}-0.020 \\
(0.022)\end{array}$ & $\begin{array}{l}-0.018 \\
(0.021)\end{array}$ & $\begin{array}{l}-0.039 \\
(0.027)\end{array}$ & $\begin{array}{l}-0.001 \\
(0.027)\end{array}$ & $\begin{array}{l}-0.022 \\
(0.026)\end{array}$ \\
\hline Own Home & $\begin{array}{c}0.007 \\
(0.018)\end{array}$ & $\begin{array}{c}0.011 \\
(0.017)\end{array}$ & $\begin{array}{c}0.005 \\
(0.017)\end{array}$ & $\begin{array}{l}0.043^{*} \\
(0.020)\end{array}$ & $\begin{array}{l}0.053^{*} \\
(0.020)\end{array}$ & $\begin{array}{c}0.034 \\
(0.019)\end{array}$ & $\begin{array}{l}-0.011 \\
(0.020)\end{array}$ & $\begin{array}{l}-0.013 \\
(0.020)\end{array}$ & $\begin{array}{l}-0.022 \\
(0.020)\end{array}$ & $\begin{array}{c}0.035 \\
(0.028)\end{array}$ & $\begin{array}{c}0.049 \\
(0.027)\end{array}$ & $\begin{array}{c}0.034 \\
(0.027)\end{array}$ \\
\hline Mortgage & $\begin{array}{l}-0.000 \\
(0.027)\end{array}$ & $\begin{array}{l}0.010 \\
(0.027)\end{array}$ & $\begin{array}{c}0.026 \\
(0.026)\end{array}$ & $\begin{array}{l}-0.016 \\
(0.019)\end{array}$ & $\begin{array}{l}-0.014 \\
(0.019)\end{array}$ & $\begin{array}{l}-0.012 \\
(0.018)\end{array}$ & $\begin{array}{l}-0.039^{*} \\
(0.019)\end{array}$ & $\begin{array}{l}-0.034 \\
(0.018)\end{array}$ & $\begin{array}{l}-0.029 \\
(0.018)\end{array}$ & $\begin{array}{l}-0.048 \\
(0.029)\end{array}$ & $\begin{array}{l}-0.041 \\
(0.028)\end{array}$ & $\begin{array}{l}-0.038 \\
(0.027)\end{array}$ \\
\hline HS Degree & $\begin{array}{l}0.041 \\
(0.029)\end{array}$ & $\begin{array}{l}0.047 \\
(0.029)\end{array}$ & $\begin{array}{l}0.027 \\
(0.028)\end{array}$ & $\begin{array}{c}0.033 \\
(0.027)\end{array}$ & $\begin{array}{c}0.032 \\
(0.027)\end{array}$ & $\begin{array}{l}0.019 \\
(0.026)\end{array}$ & $\begin{array}{l}0.028 \\
(0.026)\end{array}$ & $\begin{array}{l}0.016 \\
(0.026)\end{array}$ & $\begin{array}{l}0.006 \\
(0.025)\end{array}$ & $\begin{array}{l}0.065^{*} \\
(0.027)\end{array}$ & $\begin{array}{l}0.061^{*} \\
(0.026)\end{array}$ & $\begin{array}{l}0.057^{*} \\
(0.026)\end{array}$ \\
\hline Bachelor's Degree & $\begin{array}{l}0.119^{*} \\
(0.039)\end{array}$ & $\begin{array}{l}0.119^{*} \\
(0.038)\end{array}$ & $\begin{array}{c}0.065 \\
(0.037)\end{array}$ & $\begin{array}{c}0.053 \\
(0.036)\end{array}$ & $\begin{array}{c}0.042 \\
(0.036)\end{array}$ & $\begin{array}{c}0.023 \\
(0.035)\end{array}$ & $\begin{array}{c}0.048 \\
(0.029)\end{array}$ & $\begin{array}{c}0.033 \\
(0.029)\end{array}$ & $\begin{array}{c}0.003 \\
(0.029)\end{array}$ & $\begin{array}{l}0.117^{*} \\
(0.035)\end{array}$ & $\begin{array}{l}0.084^{*} \\
(0.034)\end{array}$ & $\begin{array}{c}0.058 \\
(0.033)\end{array}$ \\
\hline Graduate Degree & $\begin{array}{l}0.192^{*} \\
(0.035)\end{array}$ & $\begin{array}{l}0.179^{*} \\
(0.034)\end{array}$ & $\begin{array}{l}0.102^{*} \\
(0.033)\end{array}$ & $\begin{array}{l}0.123^{*} \\
(0.031)\end{array}$ & $\begin{array}{l}0.106^{*} \\
(0.031)\end{array}$ & $\begin{array}{l}0.069^{*} \\
(0.030)\end{array}$ & $\begin{array}{l}0.083^{*} \\
(0.027)\end{array}$ & $\begin{array}{l}0.072^{*} \\
(0.027)\end{array}$ & $\begin{array}{c}0.039 \\
(0.028)\end{array}$ & $\begin{array}{l}0.140^{*} \\
(0.048)\end{array}$ & $\begin{array}{l}0.116^{*} \\
(0.047)\end{array}$ & $\begin{array}{c}0.086 \\
(0.045)\end{array}$ \\
\hline Female & $\begin{array}{l}0.039^{*} \\
(0.016)\end{array}$ & $\begin{array}{l}0.030 \\
(0.016)\end{array}$ & $\begin{array}{l}0.033^{*} \\
(0.016)\end{array}$ & $\begin{array}{l}0.066^{*} \\
(0.017)\end{array}$ & $\begin{array}{l}0.057^{*} \\
(0.017)\end{array}$ & $\begin{array}{l}0.039^{*} \\
(0.016)\end{array}$ & $\begin{array}{l}0.026 \\
(0.017)\end{array}$ & $\begin{array}{l}0.026 \\
(0.017)\end{array}$ & $\begin{array}{l}0.030 \\
(0.017)\end{array}$ & $\begin{array}{l}0.041 \\
(0.022)\end{array}$ & $\begin{array}{l}0.035 \\
(0.022)\end{array}$ & $\begin{array}{l}0.021 \\
(0.022)\end{array}$ \\
\hline Age $30-44$ & $\begin{array}{l}-0.001 \\
(0.022)\end{array}$ & $\begin{array}{l}-0.006 \\
(0.022)\end{array}$ & $\begin{array}{c}0.018 \\
(0.021)\end{array}$ & $\begin{array}{l}-0.029 \\
(0.025)\end{array}$ & $\begin{array}{l}-0.012 \\
(0.025)\end{array}$ & $\begin{array}{l}-0.001 \\
(0.024)\end{array}$ & $\begin{array}{l}-0.036 \\
(0.024)\end{array}$ & $\begin{array}{l}-0.027 \\
(0.024)\end{array}$ & $\begin{array}{l}-0.019 \\
(0.024)\end{array}$ & $\begin{array}{l}-0.023 \\
(0.040)\end{array}$ & $\begin{array}{l}-0.012 \\
(0.040)\end{array}$ & $\begin{array}{c}0.006 \\
(0.039)\end{array}$ \\
\hline Age $45-64$ & $\begin{array}{c}0.012 \\
(0.024)\end{array}$ & $\begin{array}{c}0.003 \\
(0.023)\end{array}$ & $\begin{array}{c}0.026 \\
(0.022)\end{array}$ & $\begin{array}{l}0.098^{*} \\
(0.026)\end{array}$ & $\begin{array}{l}0.104^{*} \\
(0.026)\end{array}$ & $\begin{array}{l}0.087^{*} \\
(0.025)\end{array}$ & $\begin{array}{l}-0.012 \\
(0.026)\end{array}$ & $\begin{array}{l}-0.008 \\
(0.025)\end{array}$ & $\begin{array}{l}-0.013 \\
(0.026)\end{array}$ & $\begin{array}{l}-0.060 \\
(0.039)\end{array}$ & $\begin{array}{l}-0.066 \\
(0.038)\end{array}$ & $\begin{array}{l}-0.032 \\
(0.038)\end{array}$ \\
\hline Age $65+$ & $\begin{array}{c}0.034 \\
(0.037)\end{array}$ & $\begin{array}{c}0.057 \\
(0.036)\end{array}$ & $\begin{array}{c}0.061 \\
(0.035)\end{array}$ & $\begin{array}{l}0.158^{*} \\
(0.048)\end{array}$ & $\begin{array}{l}0.173^{*} \\
(0.046)\end{array}$ & $\begin{array}{l}0.157^{*} \\
(0.042)\end{array}$ & $\begin{array}{c}0.056 \\
(0.090)\end{array}$ & $\begin{array}{c}0.070 \\
(0.087)\end{array}$ & $\begin{array}{c}0.060 \\
(0.087)\end{array}$ & $\begin{array}{l}-0.077 \\
(0.050)\end{array}$ & $\begin{array}{l}-0.075 \\
(0.049)\end{array}$ & $\begin{array}{l}-0.048 \\
(0.049)\end{array}$ \\
\hline \# Children & $\begin{array}{c}-0.021^{*} \\
(0.006)\end{array}$ & $\begin{array}{c}-0.020^{*} \\
(0.006)\end{array}$ & $\begin{array}{l}-0.012 \\
(0.006)\end{array}$ & $\begin{array}{c}-0.031^{*} \\
(0.009)\end{array}$ & $\begin{array}{c}-0.029^{*} \\
(0.009)\end{array}$ & $\begin{array}{c}-0.023^{*} \\
(0.008)\end{array}$ & $\begin{array}{l}-0.007 \\
(0.008)\end{array}$ & $\begin{array}{l}-0.003 \\
(0.008)\end{array}$ & $\begin{array}{c}0.001 \\
(0.008)\end{array}$ & $\begin{array}{l}-0.001 \\
(0.008)\end{array}$ & $\begin{array}{l}0.000 \\
(0.008)\end{array}$ & $\begin{array}{c}0.005 \\
(0.007)\end{array}$ \\
\hline Voted & $\begin{array}{l}-0.046 \\
(0.026)\end{array}$ & $\begin{array}{l}-0.044 \\
(0.025)\end{array}$ & $\begin{array}{l}-0.038 \\
(0.025)\end{array}$ & $\begin{array}{c}0.032 \\
(0.030)\end{array}$ & $\begin{array}{c}0.018 \\
(0.030)\end{array}$ & $\begin{array}{l}-0.001 \\
(0.029)\end{array}$ & $\begin{array}{c}0.031 \\
(0.026)\end{array}$ & $\begin{array}{l}0.038 \\
(0.026)\end{array}$ & $\begin{array}{c}0.030 \\
(0.026)\end{array}$ & $\begin{array}{c}-0.069^{*} \\
(0.032)\end{array}$ & $\begin{array}{l}-0.046 \\
(0.032)\end{array}$ & $\begin{array}{l}-0.026 \\
(0.031)\end{array}$ \\
\hline Far Left & & $\begin{array}{l}0.152^{*} \\
(0.027)\end{array}$ & $\begin{array}{l}0.126^{*} \\
(0.026)\end{array}$ & & $\begin{array}{l}0.105^{*} \\
(0.026)\end{array}$ & $\begin{array}{l}0.087^{*} \\
(0.025)\end{array}$ & & $\begin{array}{c}0.034 \\
(0.024)\end{array}$ & $\begin{array}{l}0.072^{*} \\
(0.025)\end{array}$ & & $\begin{array}{l}0.182^{*} \\
(0.047)\end{array}$ & $\begin{array}{l}0.168^{*} \\
(0.047)\end{array}$ \\
\hline Left & & $\begin{array}{l}0.156^{*} \\
(0.022)\end{array}$ & $\begin{array}{l}0.113^{*} \\
(0.021)\end{array}$ & & $\begin{array}{l}0.108^{*} \\
(0.022)\end{array}$ & $\begin{array}{l}0.055^{*} \\
(0.022)\end{array}$ & & $\begin{array}{l}0.119^{*} \\
(0.019)\end{array}$ & $\begin{array}{l}0.116^{*} \\
(0.019)\end{array}$ & & $\begin{array}{l}0.118^{*} \\
(0.032)\end{array}$ & $\begin{array}{l}0.074^{*} \\
(0.032)\end{array}$ \\
\hline Right & & $\begin{array}{c}-0.123^{*} \\
(0.022)\end{array}$ & $\begin{array}{c}-0.124^{*} \\
(0.021)\end{array}$ & & $\begin{array}{c}-0.149^{*} \\
(0.024)\end{array}$ & $\begin{array}{l}-0.123^{*} \\
(0.024)\end{array}$ & & $\begin{array}{c}-0.123^{*} \\
(0.030)\end{array}$ & $\begin{array}{c}-0.129^{*} \\
(0.029)\end{array}$ & & $\begin{array}{c}-0.126^{*} \\
(0.027)\end{array}$ & $\begin{array}{c}-0.088^{*} \\
(0.027)\end{array}$ \\
\hline Far Right & & $\begin{array}{c}-0.183^{*} \\
(0.026)\end{array}$ & $\begin{array}{c}-0.131^{*} \\
(0.025)\end{array}$ & & $\begin{array}{c}-0.243^{*} \\
(0.030)\end{array}$ & $\begin{array}{c}-0.155^{*} \\
(0.030)\end{array}$ & & $\begin{array}{l}-0.108 \\
(0.055)\end{array}$ & $\begin{array}{l}-0.078 \\
(0.055)\end{array}$ & & $\begin{array}{c}-0.244^{*} \\
(0.035)\end{array}$ & $\begin{array}{c}-0.200^{*} \\
(0.039)\end{array}$ \\
\hline Pro-EU & & & $0.293^{*}$ & & & $0.300^{*}$ & & & $0.217^{*}$ & & & $0.244^{*}$ \\
\hline High Empathy & & & $\begin{array}{l}(0.016) \\
0.034^{*}\end{array}$ & & & $(0.018)$ & & & $(0.019)$ & & & $(0.022)$ \\
\hline High Empatny & & & $(0.015)$ & & & $\begin{array}{c}0.016 \\
(0.017)\end{array}$ & & & $\begin{array}{l}0.022 \\
(0.017)\end{array}$ & & & $\begin{array}{l}0.053^{*} \\
(0.022)\end{array}$ \\
\hline Pro-Redistribution & & & 0.011 & & & 0.030 & & & $0.064^{*}$ & & & 0.014 \\
\hline & & & $(0.016)$ & & & $(0.017)$ & & & $(0.019)$ & & & $(0.022)$ \\
\hline High Knowledge & & & $0.034^{*}$ & & & $0.096^{*}$ & & & 0.012 & & & 0.015 \\
\hline High Interest & & & $\begin{array}{l}(0.016) \\
-0.013 \\
(0.018)\end{array}$ & & & $\begin{array}{c}(0.017) \\
-0.066^{*} \\
(0.017)\end{array}$ & & & $\begin{array}{l}(0.020) \\
-0.031 \\
(0.018)\end{array}$ & & & $\begin{array}{c}(0.022) \\
-0.09)^{*} \\
(0.023)\end{array}$ \\
\hline $\mathrm{R}^{2}$ & 0.021 & 0.070 & 0.150 & 0.028 & 0.077 & 0.164 & 0.013 & 0.036 & 0.076 & 0.027 & 0.070 & 0.134 \\
\hline Adj. $R^{2}$ & 0.017 & 0.065 & 0.144 & 0.022 & 0.070 & 0.157 & 0.007 & 0.029 & 0.069 & 0.018 & 0.060 & 0.122 \\
\hline Num. obs. & 3886 & 3886 & 3886 & 3473 & 3473 & 3473 & 3471 & 3471 & 3471 & 2009 & 2009 & 2009 \\
\hline
\end{tabular}


Table C.13: Mechanism Regressions with Alternative Coding of Ideology Bins (Full Sample)

\begin{tabular}{|c|c|c|c|c|c|c|}
\hline & $\begin{array}{l}\text { Model } 1 \\
\text { Oppose } \\
\text { Grexit } \\
\text { (Binary) }\end{array}$ & $\begin{array}{l}\text { Model } 2 \\
\text { Oppose } \\
\text { Grexit } \\
\text { (Binary) }\end{array}$ & $\begin{array}{l}\text { Model } 3 \\
\text { Pro- } \\
\text { Redistribution } \\
\text { (Binary) }\end{array}$ & $\begin{array}{l}\text { Model } 4 \\
\text { High } \\
\text { Empathy } \\
\text { (Binary) }\end{array}$ & $\begin{array}{l}\text { Model } 5 \\
\text { EU } \\
\text { Support } \\
\text { (3-Point) }\end{array}$ & $\begin{array}{c}\text { Model } 6 \\
\text { Positive Expected } \\
\text { Grexit Impact } \\
\text { (3-Point) }\end{array}$ \\
\hline Far Left & $\begin{array}{l}0.102^{*} \\
(0.014)\end{array}$ & $\begin{array}{l}0.050^{*} \\
(0.013)\end{array}$ & $\begin{array}{l}0.234^{*} \\
(0.011)\end{array}$ & $\begin{array}{l}0.174^{*} \\
(0.014)\end{array}$ & $\begin{array}{l}-0.029 \\
(0.024)\end{array}$ & $\begin{array}{c}-0.195^{*} \\
(0.021)\end{array}$ \\
\hline Left & $\begin{array}{l}0.128^{*} \\
(0.011)\end{array}$ & $\begin{array}{l}0.068^{*} \\
(0.010)\end{array}$ & $\begin{array}{l}0.193^{*} \\
(0.010)\end{array}$ & $\begin{array}{l}0.102^{*} \\
(0.012)\end{array}$ & $\begin{array}{l}0.137^{*} \\
(0.018)\end{array}$ & $\begin{array}{c}-0.151^{*} \\
(0.018)\end{array}$ \\
\hline Right & $\begin{array}{c}-0.131^{*} \\
(0.013)\end{array}$ & $\begin{array}{c}-0.089^{*} \\
(0.011)\end{array}$ & $\begin{array}{c}-0.149^{*} \\
(0.013)\end{array}$ & $\begin{array}{l}-0.017 \\
(0.013)\end{array}$ & $\begin{array}{l}-0.039 \\
(0.020)\end{array}$ & $\begin{array}{l}0.135^{*} \\
(0.020)\end{array}$ \\
\hline Far Right & $\begin{array}{c}-0.207^{*} \\
(0.016)\end{array}$ & $\begin{array}{c}-0.102^{*} \\
(0.015)\end{array}$ & $\begin{array}{l}-0.137^{*} \\
(0.017)\end{array}$ & $\begin{array}{c}0.030 \\
(0.017)\end{array}$ & $\begin{array}{c}-0.277^{*} \\
(0.029)\end{array}$ & $\begin{array}{l}0.264^{*} \\
(0.028)\end{array}$ \\
\hline Pro-Redistribution & & $\begin{array}{c}0.015 \\
(0.008)\end{array}$ & & & & \\
\hline High Empathy & & $\begin{array}{c}0.014 \\
(0.008)\end{array}$ & & & & \\
\hline EU Support & & $\begin{array}{l}0.130^{*} \\
(0.005)\end{array}$ & & & & \\
\hline Positive Expected Grexit Impact & & $\begin{array}{c}-0.254^{*} \\
(0.005)\end{array}$ & & & & \\
\hline $\begin{array}{l}\text { Economic, Demographic, } \\
\text { Additional Controls }\end{array}$ & $\checkmark$ & $\checkmark$ & $\checkmark$ & $\checkmark$ & $\checkmark$ & $\checkmark$ \\
\hline $\mathrm{R}^{2}$ & 0.081 & 0.285 & 0.111 & 0.069 & 0.095 & 0.087 \\
\hline Adj. $R^{2}$ & 0.079 & 0.283 & 0.109 & 0.067 & 0.093 & 0.085 \\
\hline Num. obs. & 12839 & 12839 & 12839 & 12839 & 12839 & 12839 \\
\hline
\end{tabular}

The alternative coding of the ideology bins is as follows:

Far Left (0-1), Left (2-3), Center (4-6), Right (7-8), Far Right (9-10) 
Table C.14: Mechanism Regressions with Party ID (and L-R Score) France, Reference Party: UMP (7.7)

\begin{tabular}{|c|c|c|c|c|c|c|}
\hline & $\begin{array}{l}\text { Model } 1 \\
\text { Oppose } \\
\text { Grexit } \\
\text { (Binary) }\end{array}$ & $\begin{array}{c}\text { Model } 2 \\
\text { Oppose } \\
\text { Grexit } \\
\text { (Binary) }\end{array}$ & $\begin{array}{c}\text { Model } 3 \\
\text { Pro- } \\
\text { Redistribution } \\
\text { (Binary) }\end{array}$ & $\begin{array}{l}\text { Model } 4 \\
\text { High } \\
\text { Empathy } \\
\text { (Binary) }\end{array}$ & $\begin{array}{l}\text { Model } 5 \\
\text { EU } \\
\text { Support } \\
\text { (3-Point) }\end{array}$ & $\begin{array}{c}\text { Model } 6 \\
\text { Positive Expected } \\
\text { Grexit Impact } \\
\text { (3-Point) }\end{array}$ \\
\hline $\operatorname{EELV}(3.1)$ & $\begin{array}{l}0.247^{*} \\
(0.040)\end{array}$ & $\begin{array}{l}0.154^{*} \\
(0.036)\end{array}$ & $\begin{array}{l}0.296^{*} \\
(0.041)\end{array}$ & $\begin{array}{l}0.182^{*} \\
(0.043)\end{array}$ & $\begin{array}{l}0.230^{*} \\
(0.060)\end{array}$ & $\begin{array}{c}-0.246^{*} \\
(0.067)\end{array}$ \\
\hline FDG (1.8) & $\begin{array}{l}0.232^{*} \\
(0.041)\end{array}$ & $\begin{array}{l}0.190^{*} \\
(0.038)\end{array}$ & $\begin{array}{l}0.424^{*} \\
(0.037)\end{array}$ & $\begin{array}{l}0.248^{*} \\
(0.042)\end{array}$ & $\begin{array}{c}-0.184^{*} \\
(0.069)\end{array}$ & $\begin{array}{c}-0.219^{*} \\
(0.067)\end{array}$ \\
\hline $\mathrm{FN}(9.6)$ & $\begin{array}{c}-0.156^{*} \\
(0.028)\end{array}$ & $\begin{array}{l}-0.025 \\
(0.027)\end{array}$ & $\begin{array}{l}0.202^{*} \\
(0.028)\end{array}$ & $\begin{array}{c}0.013 \\
(0.028)\end{array}$ & $\begin{array}{c}-0.741^{*} \\
(0.044)\end{array}$ & $\begin{array}{l}0.198^{*} \\
(0.045)\end{array}$ \\
\hline PS (3.8) & $\begin{array}{l}0.232^{*} \\
(0.030)\end{array}$ & $\begin{array}{l}0.145^{*} \\
(0.028)\end{array}$ & $\begin{array}{l}0.289^{*} \\
(0.030)\end{array}$ & $\begin{array}{l}0.093^{*} \\
(0.031)\end{array}$ & $\begin{array}{l}0.231^{*} \\
(0.046)\end{array}$ & $\begin{array}{c}-0.225^{*} \\
(0.048)\end{array}$ \\
\hline UDI / MoDem (5.9) & $\begin{array}{l}0.208^{*} \\
(0.035)\end{array}$ & $\begin{array}{l}0.171^{*} \\
(0.032)\end{array}$ & $\begin{array}{l}0.102^{*} \\
(0.035)\end{array}$ & $\begin{array}{l}0.085^{*} \\
(0.035)\end{array}$ & $\begin{array}{c}0.028 \\
(0.055)\end{array}$ & $\begin{array}{c}-0.130^{*} \\
(0.057)\end{array}$ \\
\hline Pro-Redistribution & & $\begin{array}{c}0.014 \\
(0.019)\end{array}$ & & & & \\
\hline High Empathy & & $\begin{array}{c}0.025 \\
(0.018)\end{array}$ & & & & \\
\hline EU Support & & $\begin{array}{l}0.119^{*} \\
(0.013)\end{array}$ & & & & \\
\hline Positive Expected Grexit Impact & & $\begin{array}{c}-0.233^{*} \\
(0.012)\end{array}$ & & & & \\
\hline $\begin{array}{l}\text { Economic, Demographic, } \\
\text { Additional Controls }\end{array}$ & $\checkmark$ & $\checkmark$ & $\checkmark$ & $\checkmark$ & $\checkmark$ & $\checkmark$ \\
\hline $\mathrm{R}^{2}$ & 0.146 & 0.313 & 0.113 & 0.059 & 0.299 & 0.078 \\
\hline Adj. $R^{2}$ & 0.137 & 0.304 & 0.103 & 0.049 & 0.292 & 0.068 \\
\hline Num. obs. & 2345 & 2345 & 2345 & 2345 & 2345 & 2345 \\
\hline
\end{tabular}


Table C.15: Mechanism Regressions with Party ID (and L-R Score) Italy, Reference Party: Partito Democratico (3.6)

\begin{tabular}{|c|c|c|c|c|c|c|}
\hline & $\begin{array}{l}\text { Model } 1 \\
\text { Oppose } \\
\text { Grexit } \\
\text { (Binary) }\end{array}$ & $\begin{array}{l}\text { Model } 2 \\
\text { Oppose } \\
\text { Grexit } \\
\text { (Binary) }\end{array}$ & $\begin{array}{c}\text { Model } 3 \\
\text { Pro- } \\
\text { Redistribution } \\
\text { (Binary) }\end{array}$ & $\begin{array}{l}\text { Model } 4 \\
\text { High } \\
\text { Empathy } \\
\text { (Binary) }\end{array}$ & $\begin{array}{l}\text { Model } 5 \\
\text { EU } \\
\text { Support } \\
\text { (3-Point) }\end{array}$ & $\begin{array}{c}\text { Model } 6 \\
\text { Positive Expected } \\
\text { Grexit Impact } \\
\text { (3-Point) }\end{array}$ \\
\hline Forza Italia (6.7) & $\begin{array}{c}-0.289^{*} \\
(0.039)\end{array}$ & $\begin{array}{c}-0.133^{*} \\
(0.035)\end{array}$ & $\begin{array}{c}-0.202^{*} \\
(0.039)\end{array}$ & $\begin{array}{c}-0.092^{*} \\
(0.037)\end{array}$ & $\begin{array}{c}-0.478^{*} \\
(0.058)\end{array}$ & $\begin{array}{l}0.340^{*} \\
(0.064)\end{array}$ \\
\hline Fratelli Italia (7.9) & $\begin{array}{c}-0.251^{*} \\
(0.053)\end{array}$ & $\begin{array}{c}-0.135^{*} \\
(0.044)\end{array}$ & $\begin{array}{c}-0.177^{*} \\
(0.053)\end{array}$ & $\begin{array}{c}-0.113^{*} \\
(0.052)\end{array}$ & $\begin{array}{c}-0.708^{*} \\
(0.086)\end{array}$ & $\begin{array}{c}0.084 \\
(0.082)\end{array}$ \\
\hline Lega Nord (8.9) & $\begin{array}{c}-0.334^{*} \\
(0.032)\end{array}$ & $\begin{array}{c}-0.147^{*} \\
(0.031)\end{array}$ & $\begin{array}{c}-0.157^{*} \\
(0.033)\end{array}$ & $\begin{array}{c}-0.082^{*} \\
(0.032)\end{array}$ & $\begin{array}{c}-0.865^{*} \\
(0.049)\end{array}$ & $\begin{array}{l}0.283^{*} \\
(0.052)\end{array}$ \\
\hline M5S (4.7) & $\begin{array}{c}-0.246^{*} \\
(0.027)\end{array}$ & $\begin{array}{c}-0.143^{*} \\
(0.025)\end{array}$ & $\begin{array}{c}0.046 \\
(0.026)\end{array}$ & $\begin{array}{l}0.056^{*} \\
(0.026)\end{array}$ & $\begin{array}{c}-0.695^{*} \\
(0.039)\end{array}$ & $\begin{array}{c}0.070 \\
(0.043)\end{array}$ \\
\hline Sinistra EL (1.3) & $\begin{array}{l}0.085^{*} \\
(0.034)\end{array}$ & $\begin{array}{c}0.039 \\
(0.031)\end{array}$ & $\begin{array}{l}0.131^{*} \\
(0.034)\end{array}$ & $\begin{array}{l}0.145^{*} \\
(0.036)\end{array}$ & $\begin{array}{l}-0.045 \\
(0.049)\end{array}$ & $\begin{array}{c}-0.175^{*} \\
(0.059)\end{array}$ \\
\hline Pro-Redistribution & & $\begin{array}{c}0.027 \\
(0.019)\end{array}$ & & & & \\
\hline High Empathy & & $\begin{array}{c}0.007 \\
(0.020)\end{array}$ & & & & \\
\hline EU Support & & $\begin{array}{l}0.123^{*} \\
(0.013)\end{array}$ & & & & \\
\hline Positive Expected Grexit Impact & & $\begin{array}{c}-0.269^{*} \\
(0.012)\end{array}$ & & & & \\
\hline $\begin{array}{l}\text { Economic, Demographic, } \\
\text { Additional Controls }\end{array}$ & $\checkmark$ & $\checkmark$ & $\checkmark$ & $\checkmark$ & $\checkmark$ & $\checkmark$ \\
\hline $\mathrm{R}^{2}$ & 0.109 & 0.329 & 0.066 & 0.083 & 0.218 & 0.064 \\
\hline Adj. $R^{2}$ & 0.099 & 0.320 & 0.055 & 0.073 & 0.209 & 0.053 \\
\hline Num. obs. & 2165 & 2165 & 2165 & 2165 & 2165 & 2165 \\
\hline
\end{tabular}


Table C.16: Mechanism Regressions with Party ID (and L-R Score) Spain, Reference Party: PSOE (3.8)

\begin{tabular}{|c|c|c|c|c|c|c|}
\hline & $\begin{array}{l}\text { Model } 1 \\
\text { Oppose } \\
\text { Grexit } \\
\text { (Binary) }\end{array}$ & $\begin{array}{l}\text { Model } 2 \\
\text { Oppose } \\
\text { Grexit } \\
\text { (Binary) }\end{array}$ & $\begin{array}{c}\text { Model } 3 \\
\text { Pro- } \\
\text { Redistribution } \\
\text { (Binary) }\end{array}$ & $\begin{array}{l}\text { Model } 4 \\
\text { High } \\
\text { Empathy } \\
\text { (Binary) }\end{array}$ & $\begin{array}{l}\text { Model } 5 \\
\text { EU } \\
\text { Support } \\
\text { (3-Point) }\end{array}$ & $\begin{array}{c}\text { Model } 6 \\
\text { Positive Expected } \\
\text { Grexit Impact } \\
\text { (3-Point) }\end{array}$ \\
\hline Ciudadanos (5.6) & $\begin{array}{c}-0.101^{*} \\
(0.033)\end{array}$ & $\begin{array}{c}-0.083^{*} \\
(0.028)\end{array}$ & $\begin{array}{c}-0.138^{*} \\
(0.030)\end{array}$ & $\begin{array}{c}0.021 \\
(0.034)\end{array}$ & $\begin{array}{c}0.018 \\
(0.046)\end{array}$ & $\begin{array}{c}0.061 \\
(0.053)\end{array}$ \\
\hline ERC (3.7) & $\begin{array}{l}-0.007 \\
(0.044)\end{array}$ & $\begin{array}{l}0.040 \\
(0.039)\end{array}$ & $\begin{array}{c}0.003 \\
(0.038)\end{array}$ & $\begin{array}{l}-0.028 \\
(0.045)\end{array}$ & $\begin{array}{c}-0.230^{*} \\
(0.070)\end{array}$ & $\begin{array}{c}0.074 \\
(0.071)\end{array}$ \\
\hline $\mathrm{IU}(2)$ & $\begin{array}{l}0.006 \\
(0.041)\end{array}$ & $\begin{array}{l}-0.011 \\
(0.036)\end{array}$ & $\begin{array}{l}0.069^{*} \\
(0.033)\end{array}$ & $\begin{array}{l}0.106^{*} \\
(0.042)\end{array}$ & $\begin{array}{c}-0.404^{*} \\
(0.069)\end{array}$ & $\begin{array}{c}-0.205^{*} \\
(0.062)\end{array}$ \\
\hline Podemos (1.7) & $\begin{array}{l}-0.044 \\
(0.032)\end{array}$ & $\begin{array}{l}-0.018 \\
(0.028)\end{array}$ & $\begin{array}{l}0.084^{*} \\
(0.026)\end{array}$ & $\begin{array}{l}0.130^{*} \\
(0.032)\end{array}$ & $\begin{array}{c}-0.458^{*} \\
(0.048)\end{array}$ & $\begin{array}{l}-0.087 \\
(0.050)\end{array}$ \\
\hline $\mathrm{PP}(7.3)$ & $\begin{array}{c}-0.211^{*} \\
(0.038)\end{array}$ & $\begin{array}{c}-0.139^{*} \\
(0.033)\end{array}$ & $\begin{array}{l}-0.354^{*} \\
(0.036)\end{array}$ & $\begin{array}{c}-0.101^{*} \\
(0.039)\end{array}$ & $\begin{array}{l}0.110^{*} \\
(0.050)\end{array}$ & $\begin{array}{l}0.276^{*} \\
(0.063)\end{array}$ \\
\hline Pro-Redistribution & & $\begin{array}{l}0.006 \\
(0.022)\end{array}$ & & & & \\
\hline High Empathy & & $\begin{array}{l}-0.016 \\
(0.019)\end{array}$ & & & & \\
\hline EU Support & & $\begin{array}{l}0.109^{*} \\
(0.013)\end{array}$ & & & & \\
\hline Positive Expected Grexit Impact & & $\begin{array}{c}-0.303^{*} \\
(0.012)\end{array}$ & & & & \\
\hline $\begin{array}{l}\text { Economic, Demographic, } \\
\text { Additional Controls }\end{array}$ & $\checkmark$ & $\checkmark$ & $V$ & $\checkmark$ & $\checkmark$ & $\checkmark$ \\
\hline $\mathrm{R}^{2}$ & 0.037 & 0.286 & 0.142 & 0.069 & 0.152 & 0.062 \\
\hline Adj. $R^{2}$ & 0.026 & 0.277 & 0.132 & 0.058 & 0.142 & 0.051 \\
\hline Num. obs. & 2166 & 2166 & 2166 & 2166 & 2166 & 2166 \\
\hline
\end{tabular}


Table C.17: Mechanism Regressions with Party ID (and L-R Score) United Kingdom, Reference Party: Conservative (7)

\begin{tabular}{|c|c|c|c|c|c|c|}
\hline & $\begin{array}{l}\text { Model } 1 \\
\text { Oppose } \\
\text { Grexit } \\
\text { (Binary) }\end{array}$ & $\begin{array}{l}\text { Model } 2 \\
\text { Oppose } \\
\text { Grexit } \\
\text { (Binary) }\end{array}$ & $\begin{array}{c}\text { Model } 3 \\
\text { Pro- } \\
\text { Redistribution } \\
\text { (Binary) }\end{array}$ & $\begin{array}{l}\text { Model } 4 \\
\text { High } \\
\text { Empathy } \\
\text { (Binary) }\end{array}$ & $\begin{array}{l}\text { Model } 5 \\
\text { EU } \\
\text { Support } \\
\text { (3-Point) }\end{array}$ & $\begin{array}{c}\text { Model } 6 \\
\text { Positive Expected } \\
\text { Grexit Impact } \\
\text { (3-Point) }\end{array}$ \\
\hline Green (1.9) & $\begin{array}{l}0.150^{*} \\
(0.054)\end{array}$ & $\begin{array}{c}0.029 \\
(0.050)\end{array}$ & $\begin{array}{l}0.413^{*} \\
(0.048)\end{array}$ & $\begin{array}{l}0.143^{*} \\
(0.049)\end{array}$ & $\begin{array}{l}0.430^{*} \\
(0.080)\end{array}$ & $\begin{array}{c}-0.229^{*} \\
(0.087)\end{array}$ \\
\hline Labour (3.6) & $\begin{array}{l}0.131^{*} \\
(0.031)\end{array}$ & $\begin{array}{c}0.041 \\
(0.030)\end{array}$ & $\begin{array}{l}0.415^{*} \\
(0.029)\end{array}$ & $\begin{array}{l}0.104^{*} \\
(0.031)\end{array}$ & $\begin{array}{l}0.363^{*} \\
(0.051)\end{array}$ & $\begin{array}{c}-0.136^{*} \\
(0.049)\end{array}$ \\
\hline LibDem (4.9) & $\begin{array}{l}0.203^{*} \\
(0.050)\end{array}$ & $\begin{array}{l}0.063 \\
(0.047)\end{array}$ & $\begin{array}{l}0.319^{*} \\
(0.047)\end{array}$ & $\begin{array}{l}0.106^{*} \\
(0.048)\end{array}$ & $\begin{array}{l}0.543^{*} \\
(0.072)\end{array}$ & $\begin{array}{c}-0.272^{*} \\
(0.082)\end{array}$ \\
\hline $\operatorname{UKIP}(9.1)$ & $\begin{array}{c}-0.141^{*} \\
(0.030)\end{array}$ & $\begin{array}{c}-0.059^{*} \\
(0.029)\end{array}$ & $\begin{array}{l}0.177^{*} \\
(0.035)\end{array}$ & $\begin{array}{c}0.010 \\
(0.035)\end{array}$ & $\begin{array}{c}-0.486^{*} \\
(0.054)\end{array}$ & $\begin{array}{l}0.126^{*} \\
(0.053)\end{array}$ \\
\hline Pro-Redistribution & & $\begin{array}{c}0.027 \\
(0.024)\end{array}$ & & & & \\
\hline High Empathy & & $\begin{array}{c}0.042 \\
(0.022)\end{array}$ & & & & \\
\hline EU Support & & $\begin{array}{l}0.121^{*} \\
(0.014)\end{array}$ & & & & \\
\hline Positive Expected Grexit Impact & & $\begin{array}{c}-0.226^{*} \\
(0.014)\end{array}$ & & & & \\
\hline $\begin{array}{l}\text { Economic, Demographic, } \\
\text { Additional Controls }\end{array}$ & $\checkmark$ & $\checkmark$ & $\checkmark$ & $\checkmark$ & $\checkmark$ & $\checkmark$ \\
\hline $\mathrm{R}^{2}$ & 0.089 & 0.274 & 0.199 & 0.066 & 0.250 & 0.047 \\
\hline Adj. $R^{2}$ & 0.076 & 0.261 & 0.187 & 0.052 & 0.238 & 0.033 \\
\hline Num. obs. & 1548 & 1548 & 1548 & 1548 & 1548 & 1548 \\
\hline
\end{tabular}


Table C.18: Proportion of Total Ideology Effect (in linear form) on Grexit Opposition (Binary) Mediated by...

\begin{tabular}{lrrrr}
\hline Mediator: & Pro-Redistribution & High Empathy & EU Support & Expected Grexit Impact \\
\hline 95\% CI Lower & 0.00177 & 0.00752 & 0.08953 & 0.32311 \\
Point Estimate & 0.02435 & 0.01463 & 0.11759 & 0.36031 \\
$95 \%$ CI Upper & 0.05262 & 0.02327 & 0.13878 & 0.39770 \\
\hline
\end{tabular}

Note: This table reports the results of a formal causal mediation analysis. The analysis employs the Baron-Kenny linear structural equation models (LSEM), with ideology treated as a linear 11-point variable and the full set of economic, social, and demographic controls included as covariates. Confidence intervals are generated via the bootstrap method. The mediation package in $\mathrm{R}$ was used to implement the causal mediation analysis. See Tingley, D., Yamamoto, T., Hirose, K., Keele, L., \& Imai, K. (2014). "mediation: R Package for Causal Mediation Analysis." Journal of Statistical Software, 59(5).

Table C.19: Proportion of Total Ideology Effect (in linear form) on Grexit Opposition (5-Point Version) Mediated by...

\begin{tabular}{lrrrr}
\hline Mediator: & Pro-Redistribution & High Empathy & EU Support & Expected Grexit Impact \\
\hline 95\% CI Lower & 0.01173 & 0.00547 & 0.07394 & 0.27160 \\
Point Estimate & 0.02727 & 0.01386 & 0.10025 & 0.31134 \\
$95 \%$ CI Upper & 0.04868 & 0.02535 & 0.11998 & 0.33326 \\
\hline
\end{tabular}

Note: This table reports the results of a formal causal mediation analysis. The analysis employs the Baron-Kenny linear structural equation models (LSEM), with ideology treated as a linear 11-point variable and the full set of economic, social, and demographic controls included as covariates. Confidence intervals are generated via the bootstrap method. The mediation package in $\mathrm{R}$ was used to implement the causal mediation analysis. See Tingley, D., Yamamoto, T., Hirose, K., Keele, L., \& Imai, K. (2014). "mediation: R Package for Causal Mediation Analysis." Journal of Statistical Software, 59(5). 
Table C.20: Investigating Interactions between Ideology and Knowledge of European Debt Crisis (Binary) in Explaining Opposition to Grexit

\begin{tabular}{|c|c|c|c|c|c|}
\hline & Full & France & Italy & Spain & UK \\
\hline Far Left & $\begin{array}{l}0.104^{*} \\
(0.017)\end{array}$ & $\begin{array}{l}0.147^{*} \\
(0.029)\end{array}$ & $\begin{array}{l}0.085^{*} \\
(0.028)\end{array}$ & $\begin{array}{l}0.037 \\
(0.038)\end{array}$ & $\begin{array}{l}0.144^{*} \\
(0.050)\end{array}$ \\
\hline Left & $\begin{array}{l}0.088^{*} \\
(0.017)\end{array}$ & $\begin{array}{l}0.117^{*} \\
(0.030)\end{array}$ & $\begin{array}{l}0.077^{*} \\
(0.028)\end{array}$ & $\begin{array}{c}0.007 \\
(0.041)\end{array}$ & $\begin{array}{l}0.135^{*} \\
(0.043)\end{array}$ \\
\hline Right & $\begin{array}{c}-0.080^{*} \\
(0.017)\end{array}$ & $\begin{array}{l}-0.021 \\
(0.028)\end{array}$ & $\begin{array}{c}-0.111^{*} \\
(0.029)\end{array}$ & $\begin{array}{c}-0.128^{*} \\
(0.048)\end{array}$ & $\begin{array}{r}-0.102^{*} \\
(0.038)\end{array}$ \\
\hline Far Right & $\begin{array}{c}-0.178^{*} \\
(0.017)\end{array}$ & $\begin{array}{c}-0.145^{*} \\
(0.028)\end{array}$ & $\begin{array}{c}-0.214^{*} \\
(0.030)\end{array}$ & $\begin{array}{l}-0.112 \\
(0.065)\end{array}$ & $\begin{array}{r}-0.189^{*} \\
(0.040)\end{array}$ \\
\hline Knowledgeable & $\begin{array}{c}0.025 \\
(0.018)\end{array}$ & $\begin{array}{c}0.044 \\
(0.035)\end{array}$ & $\begin{array}{c}0.045 \\
(0.042)\end{array}$ & $\begin{array}{c}0.000 \\
(0.034)\end{array}$ & $\begin{array}{l}-0.018 \\
(0.038)\end{array}$ \\
\hline Knowledgeable ${ }^{*}$ Far Left & $\begin{array}{c}0.046 \\
(0.025)\end{array}$ & $\begin{array}{c}0.087 \\
(0.049)\end{array}$ & $\begin{array}{c}0.052 \\
(0.055)\end{array}$ & $\begin{array}{c}0.055 \\
(0.047)\end{array}$ & $\begin{array}{c}0.111 \\
(0.074)\end{array}$ \\
\hline Knowledgeable $*$ Left & $\begin{array}{c}0.035 \\
(0.025)\end{array}$ & $\begin{array}{c}0.014 \\
(0.051)\end{array}$ & $\begin{array}{c}0.019 \\
(0.057)\end{array}$ & $\begin{array}{l}0.112^{*} \\
(0.049)\end{array}$ & $\begin{array}{l}-0.026 \\
(0.065)\end{array}$ \\
\hline Knowledgeable $*$ Right & $\begin{array}{c}0.022 \\
(0.027)\end{array}$ & $\begin{array}{l}-0.007 \\
(0.051)\end{array}$ & $\begin{array}{c}0.024 \\
(0.062)\end{array}$ & $\begin{array}{c}0.045 \\
(0.058)\end{array}$ & $\begin{array}{c}0.070 \\
(0.058)\end{array}$ \\
\hline Knowledgeable * Far Right & $\begin{array}{l}-0.003 \\
(0.029)\end{array}$ & $\begin{array}{l}-0.068 \\
(0.050)\end{array}$ & $\begin{array}{c}0.019 \\
(0.064)\end{array}$ & $\begin{array}{l}-0.006 \\
(0.080)\end{array}$ & $\begin{array}{c}0.040 \\
(0.061)\end{array}$ \\
\hline $\begin{array}{l}\text { Economic, Demographic, } \\
\text { Additional Controls }\end{array}$ & $\checkmark$ & $\checkmark$ & $\checkmark$ & $\checkmark$ & $\checkmark$ \\
\hline Country Fixed Effects & $\checkmark$ & & & & \\
\hline $\begin{array}{l}\text { P-value from F-Test of } \\
\text { Joint Significance of Interactions }\end{array}$ & 0.305 & 0.084 & 0.932 & 0.205 & 0.368 \\
\hline $\mathrm{R}^{2}$ & 0.084 & 0.077 & 0.080 & 0.039 & 0.077 \\
\hline Adj. $R^{2}$ & 0.082 & 0.070 & 0.072 & 0.031 & 0.064 \\
\hline Num. obs. & 12839 & 3886 & 3473 & 3471 & 2009 \\
\hline
\end{tabular}

